Falcón et al. Frugivory and seed dispersal by chelonians

\title{
Frugivory and seed dispersal by chelonians: A review and synthesis
}

$$
\text { Wilfredo Falcón }{ }^{1,+} \text {, Don Moll }{ }^{2} \text { and Dennis Hansen }{ }^{1,3}
$$

${ }^{1}$ Institute of Evolutionary Biology and Environmental Studies, University of Zurich, Winterthurerstrasse 190, 8057 Zurich, Switzerland

${ }^{2}$ Department of Biology, Missouri State University, 901 S. National Ave., Springfield, MO 65897, U.S.A.

${ }^{3}$ Zoological Museum of the University of Zurich, Karl-Schmid-Strasse 4, 8006 Zurich, Switzerland

${ }^{+}$Current address: Bureau of Research and Conservation of Habitats and Biodiversity, Puerto Rico Department of Natural and Environmental Resources, P.O. Box 366147 San Juan, PR 00936, USA

Corresponding author: wfalcon.research@gmail.com 
Falcón et al. Frugivory and seed dispersal by chelonians

\section{Abstract}

In recent years, it has become clear that frugivory and seed dispersal (FSD) by turtles and tortoises is much more common than previously thought. Yet, a review and synthesis is lacking. We here review published and unpublished records of chelonian FSD, and assess the role of chelonians as seed dispersers, from individual species to the community level. We first discuss the distribution of chelonian FSD and the characteristics of the fruit and/or seed species eaten and dispersed by chelonians. We then use the seed dispersal efficiency framework to explore the quantitative and qualitative components of seed dispersal by tortoises and turtles, embarking on a journey from when the fruits and/or seeds are consumed, to when and where they are deposited, and assess how efficient chelonians are as seed dispersers. We finally discuss chelonian FSD in the context of communities and chelonians as megafauna. We found that a substantial proportion of the world's aquatic and terrestrial turtles and a major part of testudinid tortoises (70 species in 12 families) include fruits and/or seeds in their diet, and that furits of at least 588 plant species in 120 families are ingested and/or dispersed by chelonians. For some chelonians, overall or in certain seasons, fruit may even form the largest part of their diet. Contrary to seed dispersal by lizards, the other major reptilian frugivores, chelonian FSD is not an island phenomenon in terms of geographic distribution. Nevertheless, on islands especially tortoises are often among the largest native terrestrial vertebrates - or were, until humans got there. We synthesize our knowledge of chelonian FSD, and discuss the relevance of our findings for conservation and restoration, especially in relation to rewilding with large and giant tortoises. 
bioRxiv preprint doi: https://doi.org/10.1101/379933; this version posted July 30,2018. The copyright holder for this preprint (which was not certified by peer review) is the author/funder, who has granted bioRxiv a license to display the preprint in perpetuity. It is made available under aCC-BY-NC-ND 4.0 International license.

\section{Falcón et al. Frugivory and seed dispersal by chelonians}

Keywords: Angiosperms, Testudines, tortoises, turtles, plant-animal interactions,

rewilding 
Falcón et al. Frugivory and seed dispersal by chelonians

\section{Resumen}

En años recientes, se ha hecho claro que la frugivoría y dispersión de semillas (FDS) llevada a cabo por tortugas (quelónidos) es más común de lo antes pensado. No obstante, todavía carecíamos de una revisión y síntesis sobre este tema. En este artículo, revisamos récords (publicados y no publicados) sobre FDS por quelónidos, y evaluamos su rol como dispersores de semillas, desde el nivel de individuos, al nivel de comunidades. Primero, discutimos la distribución de FDS por quelónidos, y las características de las especies de frutos y/o semillas consumidas y dispersadas por tortugas. Luego hacemos uso del concepto de la eficiencia de dispersión de semillas como marco de referencia para explorar los componentes cualitativos y cuantitativos de la FDS por quelónidos, embarcándonos en un viaje desde cuando los frutos y/o semillas son consumidas, hasta cuando son depositadas. También evaluamos cuán eficientes son los quelónidos como dispersores de semillas. Finalmente procedemos a discutir la FDS por quelónidos en el contexto de comunidades, y como 'megafauna'. Encontramos que una proporción substancial de las tortugas acuáticas del mundo y la mayor parte de las tortugas testudínidas (70 especies en 12 familias) incluyen frutos y/o semillas en su dieta que abarcan al menos 588 especies de plantas en 120 familias. En algunas especies, en general o en algunas estaciones, la mayor parte de su dieta está conformada por frutas y/o semillas. Más importante aún, y contrario a las lagartijas, que son otro grupo importante de reptiles que incurre en FDS, la frugivoría y dispersión de semillas por quelónidos no es un fenómeno de islas solamente, en términos de distribución geográfica. Empero, en islas, especialmente las tortugas terrestres, están entre los vertebrados nativos de mayor tamaño-o lo estuvieron, hasta que los humanos 
bioRxiv preprint doi: https://doi.org/10.1101/379933; this version posted July 30,2018 . The copyright holder for this preprint (which was not certified by peer review) is the author/funder, who has granted bioRxiv a license to display the preprint in perpetuity. It is made available under aCC-BY-NC-ND 4.0 International license.

Falcón et al. Frugivory and seed dispersal by chelonians

llegaron a ellas. En este artículo, hacemos una síntesis de las lecciones aprendidas

hasta ahora sobre la FDS por quelónidos, y discutimos la relevancia de nuestros

hallazgos para la conservación y restauración, especialmente en relación a proyectos

de resilvestrar ('rewilding') con tortugas gigantes o de gran tamaño. 


\section{Falcón et al. Frugivory and seed dispersal by chelonians}

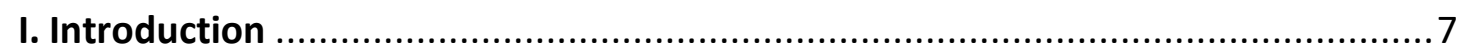

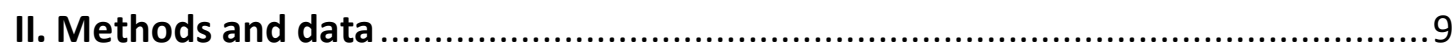

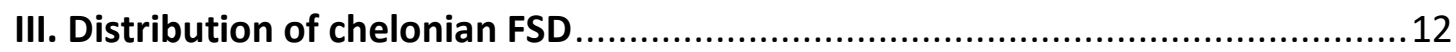

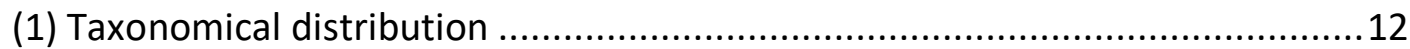

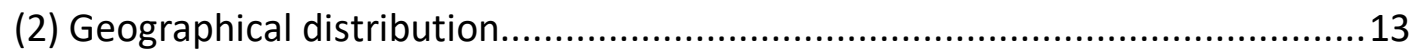

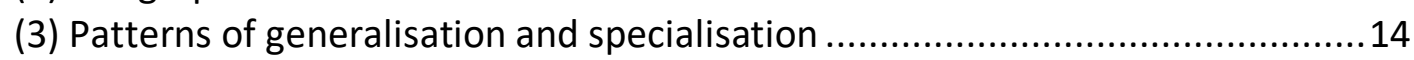

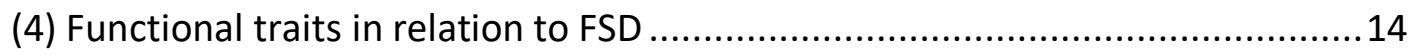

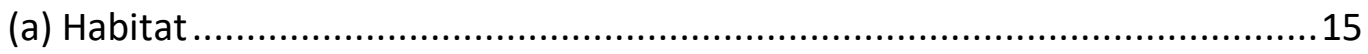

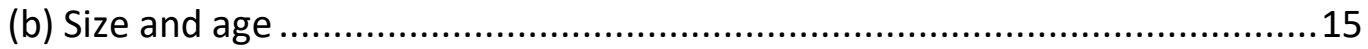

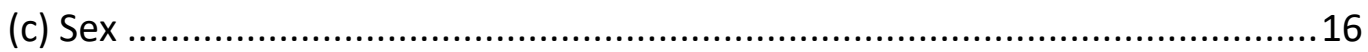

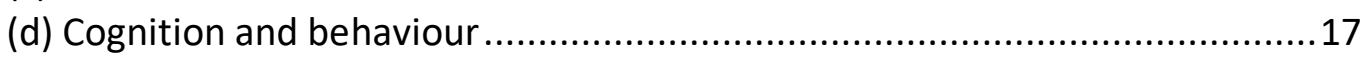

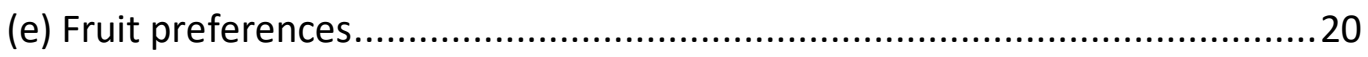

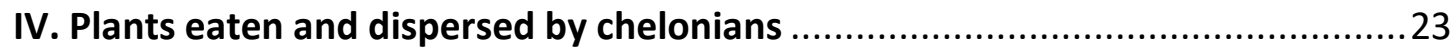

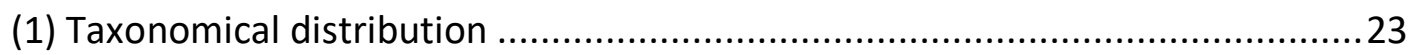

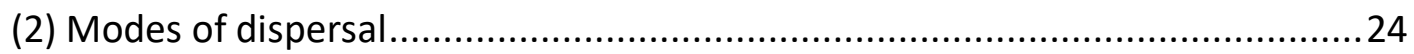

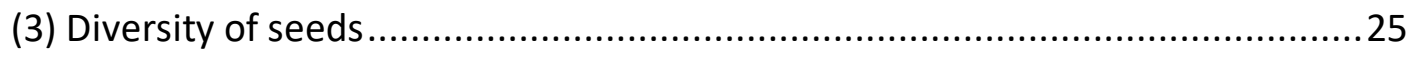

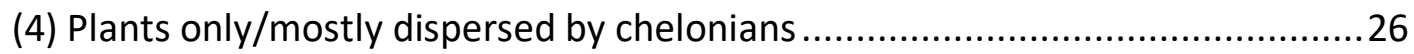

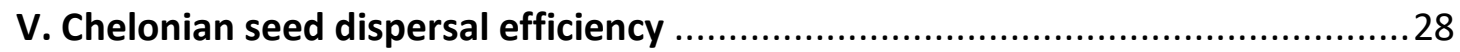

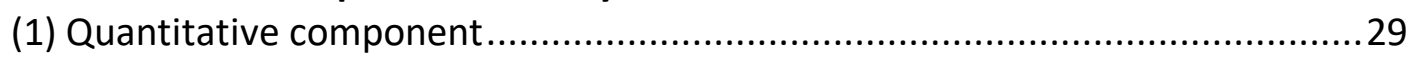

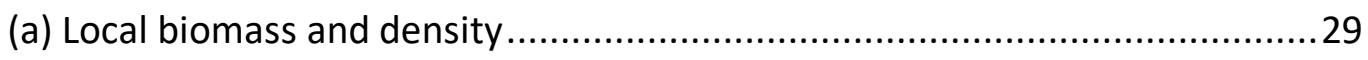

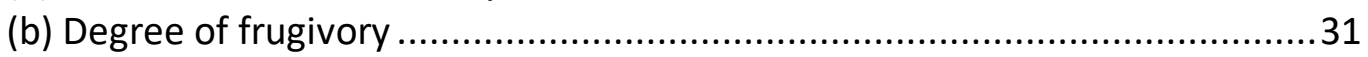

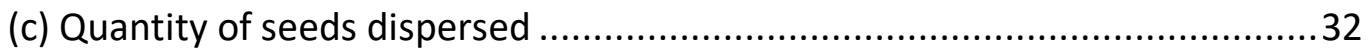

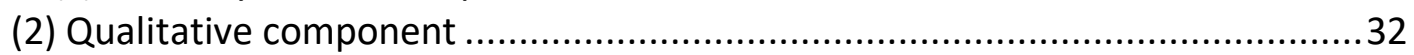

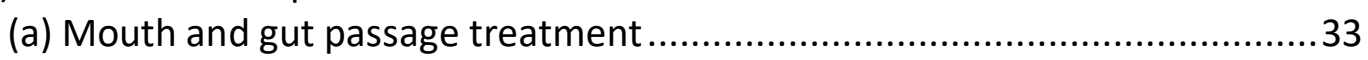

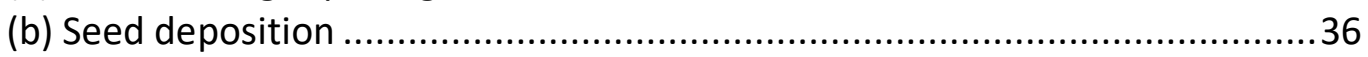

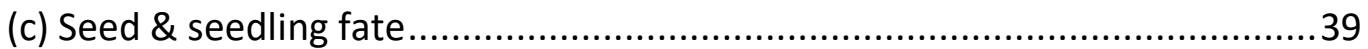

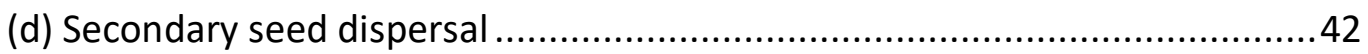

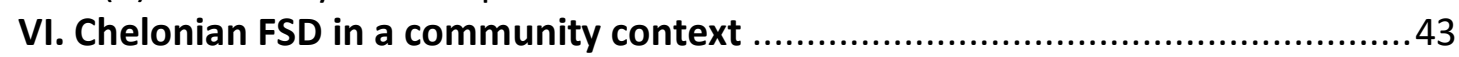

VII. Chelonians as megafaunal seed dispersers ..............................................46

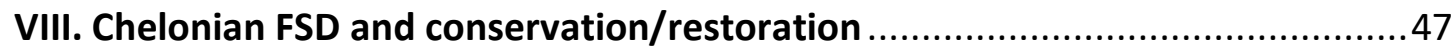

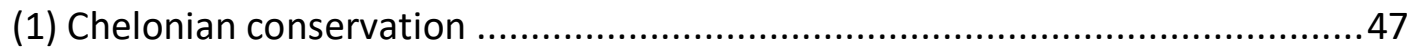

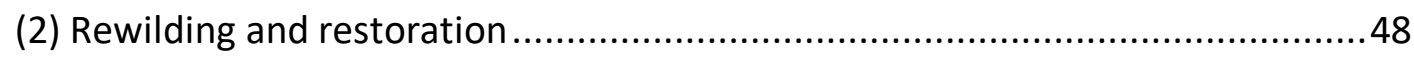

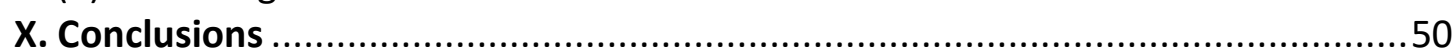

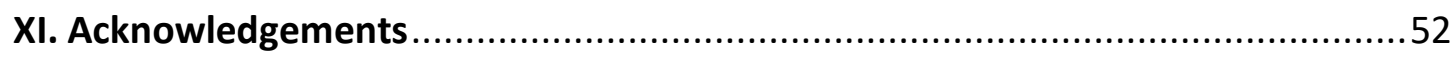

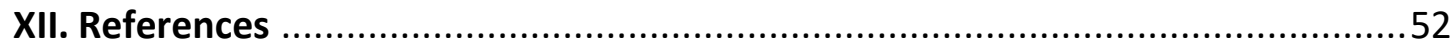


Falcón et al. Frugivory and seed dispersal by chelonians

\section{Introduction}

Animal-mediated seed dispersal is the process by which animals disperse the seeds away from the mother plant (Fig. 1), and is an important ecological function that has profound ecological and evolutionary implications in ecosystems (Howe \&

Smallwood, 1982; Rezende et al., 2007; Stoner \& Henry, 2008). The distribution and ecology of frugivory and seed dispersal (FSD) in most major vertebrate taxa has been thoroughly investigated and results synthesised (Estrada \& Fleming, 1986; Levey, Silva, \& Galetti, 2002), most recently for lizards (Iverson, 1985; Olesen \& Valido, 2003; Valido \& Olesen, 2007; Whitaker, 2011), and a start has even been made for crocodilians (Platt et al., 2013). However, a thorough overview and synthesis is still missing for chelonians.

Reviewing the origin and rise of frugivory and seed dispersal through deep time, Tiffney (2004) established that plants had the necessary morphological features for vertebrate dispersal by the Late Carboniferous (323.2-298.9 Ma), and that by the middle of the Mesozoic (252-66 Ma), several reptile lineages could have established specific FSD associations with plants. Given the long evolutionary history of chelonians, and the generally broad diet of many extant chelonians could have been among the early dispersers and 'first movers' in the evolutionary ecology of fruits (Ridley, 1930; van der Pijl, 1969; Tiffney, 1986; 2004). Perhaps the earliest example of frugivory by chelonians comes from a Campanian (83.6-72.1 Ma) coprolite that likely originated from a turtle, and that contained ca. 200 achenes of a Ranunculaceae sp. (Rodriguez-de la Rosa, Cevallos-Ferriz, \& Silva-Pineda, 1998). Two fossilised specimens of Stylemys tortoises from the Oligocene (33.9-23.03 Ma) in 
Falcón et al. Frugivory and seed dispersal by chelonians

South Dakota contained hackberry (Celtis) seeds (Marron \& Moore, 2013). On the

Bahamas, two out of three extremely well-preserved individual carapaces of the recently extinct (4,200-1,200 BP) giant tortoise (Chelonoidis alhuryorum) contained many seeds of two large-fruited species (wild mastic, Mastichodendron foetidissimum, and satinleaf Chrysophyllum oliviforme; both Sapotaceae) (Steadman et al., 2007; Franz \& Franz, 2009). In historical times, now-extinct giant tortoises (Cylindraspis spp.) of the Mascarene Islands were observed by early settlers to include fruit in their diet. In Mauritius in the late 1600s the tortoises were reported to eat 'apples' (= endemic ebony Diospyros, Ebenaceae, and Sapotaceae fruits) (Hume \& Winters, 2016). On nearby Rodrigues Island, the exiled French Huguenot François Leguat and his men ate many fruits from the forest, but "left the dates [= palm fruits, Arecaceae] for the turtles [= giant tortoises, Cylindraspis spp.]" (Leguat, 1708).

One of the first modern, experimental FSD studies was Rick \& Bowman's (1961) classic paper on how the germination rate of an endemic Galápagos tomato was dramatically improved by passing through the gut of the endemic giant tortoises. Additionally, Hnatiuk's (1978) study of germinating seeds from the feces of Aldabra giant tortoises, and Iverson's (1987) discussionof the likely frugivore mutualistsof the highly specialized Tambalacoque tree (Sideroxylon grandis; Sapotaceae), are two early examples of seminal thinking about the potential for seed dispersal interactions and germination enhancement of tortoises and island plants. It is thus ironic that, despite several calls for studies of turtles as seed dispersers (e.g., Moll \& Jansen, 1995; Pérez-Emán \& Paolillo, 1997), our understanding of chelonian FSD has progressed very little since then. In this review, we aim to summarise 
Falcón et al. Frugivory and seed dispersal by chelonians

published and unpublished information about chelonian FSD in the wild, and

synthesise and discuss the role of chelonians as frugivores and seed dispersers. We

first present an overview of the taxonomical distribution of chelonian FSD, as well as

of the taxonomical distribution of plants consumed by chelonians. We then use the

concept of seed dispersal effectiveness (SDE) (Schupp, 1993; Schupp, Jordano, \&

Gómez, 2010) to discuss the quantitative and qualitative aspects of chelonian seed

dispersal. We progress to discuss the function of chelonians as megafaunal seed

dispersers in the FSD community, and their role in conservation and restoration efforts.

\section{Methods and data}

To synthesise data on FSD by chelonians, we performed a comprehensive literature search that included scientific articles, books, monographs, and theses. We used Google Scholar (http://scholar.google.com/; Google Inc.), as it has been found to include and exceed the results of other commonly used literature databases (specifically WoS and Scopus; see Svenning et al., 2016). We used the following search terms: 'diet', 'frugivory', 'seed dispersal', in combination with the Latin genera of chelonians (from van Dijk et al., 2014), or the keywords 'chelonian', 'tortoise', or 'turtle'. No constraints on the year of publication or language were imposed (i.e., we found some articles in other languages, e.g., Spanish). We filtered the search results by reading the abstracts, and also went through the references of each text found to identify other potentially suitable articles. We added literature known by the authors to include diet information, but which did not appear in our search (mostly books). In addition, we added unpublished data based on our own 
Falcón et al. Frugivory and seed dispersal by chelonians

observations and those shared by various researchers. For diet data, we only included information based on wild chelonians. For germination and gut passage experiments we included studies using captive chelonians conducted with fruits found in the natural habitat of the species. To give a more complete overview of some of the main variables that determine the outcome of seed dispersal, we reviewed information on gut retention time (GRT), and on movement ecology and habitat range of chelonians. We used the same approach as above, using each of the search terms, 'gut retention time', 'movement', 'activity' and 'home range' together with 'tortoise', 'turtle' or 'chelonian'. See Supplementary Materials S1 for the resulting reference lists.

We followed van Dijk et al. (2014) for chelonian taxonomy, and the iPlant Collaborative for plant taxonomy (Boyle et al., 2013;

http://tnrs.iplantcollaborative.org/).We used the amniote life-history database for data on chelonian body mass (Myhrvold et al., 2015). When studies only showed results graphically, we extracted the data from figures using WebPlotDigitizer ver. 4.0 (Rohatgi, 2017; https://automeris.io/WebPlotDigitizer/). We analysed and visualised the data using R v. 3.3.3 (R Core Team, 2017) and the package 'ggplot2' (Wickham, 2016).

We were able to extract data from a total of 167 studies on chelonian FSD, germination, GRT, and movement. We found a total of 106 studies containing data on FSD by wild chelonians. These arose from either focused FSD studies (i.e., studies focusing directly on the role of chelonians as frugivores and/or seed dispersers; $n=$ 24), partial FSD studies (i.e., studies that examine diet in relation to/in a framing of FSD or examine gut passage, but not germination; $n=70$ ), or diet studies (not 
Falcón et al. Frugivory and seed dispersal by chelonians

framed in an FSD context; $\mathrm{n}=12$ ). The studies used several methods to obtain data on FSD by chelonians, including direct observation, camera traps (e.g., Wang et al., 2011), stomach flushing (e.g., Legler, 1977), or analysis of collected faeces (e.g., Nogales et al., 2017). Faecal collection methods ranged from simple picking up, to more creative approaches, such as collection with a miniature wheeled barrow mounted behind the animal (Josseaume, 2002), and, for marine turtles, collecting in cloaca-mounted bags (Amorocho \& Reina, 2008). Determination of the seed content in the faeces was done with either direct counts of seeds, or counting any seeds that germinated from the dung (e.g., Hnatiuk, 1978). For chelonian GRT, we found 37 studies, which were conducted by feeding fruits and/or artificial particles. Finally, we found 24 studies on chelonian movement and home ranges.

There are inherent biases associated with the different methodologies when estimating chelonian FSD. In dietary studies, seeds might often be overlooked, or underreported/not specifically mentioned as plant diet components. For example, Mouden et al. (2006) have a long list of plants recorded in scat of the spur-thighed tortoise (Testudo graeca), many, but not all of which, overlap with those of Cobo \& Andreu (1988), who specifically studied seeds dispersed by T. graeca. Also, Kabigumila (2001) and Hansen, Johnson, \& Van Devender (1976) provide a long list of food plants found in the scat of the leopard tortoise (Stigmochelys pardalis) and the Mojave desert tortoise (Gopherus agassizii), respectively, but they did not specify whether these were fruits, seeds or other plant parts. Faecal analysis alone may provide a biased account of a species' diet. For example, de Lima Magnusson, \& da Costa (1997) describe the red side-necked turtle (Rhinemys rufipes) as a major frugivore "palm specialist" based on faecal analysis, but a subsequent study by 
Falcón et al. Frugivory and seed dispersal by chelonians

Caputo \& Vogt (2008), using stomach flushes, found relatively larger amounts of animal food items. Thus, faecal analysis tends to record more plant matter, while it can grossly underrepresent the importance of animal matter in the diet (Caputo \& Vogt, 2008). However, using only stomach flushing may underestimate frugivory, as large seeds are hard to dislodge (Kennett \& Tory, 1996; de Lima et al., 1997). A combination of both approaches, where possible, would seem to be ideal. Another aspect which can bias the available data is the seasonality in the diet of some chelonians, where fruit may only be a major part of the diet in some season(s). Short-term studies that do not span different seasons may underestimate fruit consumption and thus the potential for seed dispersal. This is important to into consideration, because only $9 \%$ of the studies we found considered seasonality in the diet of chelonians. All these factors underscore the need for a more comprehensive dietary sampling when considering the feeding type of chelonians and their role as frugivores and seed dispersers.

\section{Distribution of chelonian FSD}

\section{(1) Taxonomical distribution}

Chelonians comprise about 335 species, of which 275 are turtles and 60 are tortoises, spanning 94 genera in 14 families (van Dijk et al., 2014). We documented FSD in a total of 72 species with, distributed across all major chelonian phylogenetic groups (Table 2; except for Dermochelyidae, with the marine leatherback turtle, Dermochelys coriacea, as the only extant species).

There was a notable gap in FSD in the branches containing Platemys platychephala to Acanthochelys spp. (Chelidae), Pelochelys spp. and Chitra spp. 
Falcón et al. Frugivory and seed dispersal by chelonians

(Trionichydae), and containing from Orlitia borneensis to Pangshura smithii

(Geomydidae). However, FSD was recorded in other species within these three

families. This pattern is likely due to the lack of focused dietary or FSD studies on

these species. Moreover, as we will see below, habitat and seasonal influences on

the diet of these groups may influence the levels of FSD in different locations and times of the year, therefore affecting sampling results. The few other chelonian species without any reported FSD have been described as purely carnivorous. Thus, frugivory is widespread in Testudines, with most taxa having at least one frugivorous representative at the genus level.

\section{(2) Geographical distribution}

Chelonians are widely distributed across the world, inhabiting habitats from tropical to temperate, from continents to islands and oceans, and they include terrestrial, aquatic and semi-aquatic, as well as marine species (see van Dijk et al., 2014 for individual species distributions). Chelonian species richness peaks in the southeastern USA, the Ganges Delta, Southeast Asia, and northern South America (Fig. 2a; data from Roll et al., 2017, provided by Y Itescu). Thus, unlike FSD by lizards (Olesen \& Valido, 2003), FSD by chelonians is not restricted to islands, and they can thus potentially play a major role in continental and island ecosystems alike.The geographic distribution of species richness of chelonian species that engage in FSD is concentrated in the south-eastern USA and northern South America, highlighting the underrepresentation of studies for especially south-east Asia (Fig. 2b). 
Falcón et al. Frugivory and seed dispersal by chelonians

\section{(3) Patterns of generalisation and specialisation}

Specialisation or generalisation on fruits varies depending on the chelonian species, as expected by the different main feeding types (herbivores, carnivores or omnivores). Frugivorous tortoises can vary from generalist, specialist to opportunistic frugivores. For example, Chelonoidis tortoises in South America are generalist frugivores, consuming fruits having a variety of traits (Moskovits, 1985; Guzman \& Stevenson, 2008). At the opposite end of the spectrum, we have the highly specialised Gibba turtle (Mesoclemys gibba [Phrynops gibbus]) that has been found to feed almost exclusively on palm fruits (Mauritia flexuosa, Aracaceae) during part of the year in the Rio Negro Basin in Brazil (Caputo and Vogt, 2008). Other species such as the common snapping turtle (Chelydra serpentina) are omnivorous, incorporating roughly the same amount of plant material (including fruits) and animal material in their diet (Ernst \& Lovich, 2009). Lastly, there are species that are mostly carnivorous, which will eat fruits opportunistically, such as Blanding's turtle (Emydoidea blandingii) (Rowe, 1992) and hinge-back tortoises (Kinixys spp.) (Luiselli, 2003). Overall, most frugivorous chelonian species are generalist frugivores that also include other plant material in their diet; this is especially true for tortoises (Testudinidae).

\section{(4) Functional traits in relation to FSD}

Frugivore species have inter- and intraspecific differences in functional traits, such as habits, size and age, sex, cognition and preferences, which may result in large differences in the seed dispersal services they provide (Jordano et al., 2007; Zwolak, 
Falcón et al. Frugivory and seed dispersal by chelonians

2017). Knowledge about these traits will help us understand the role of specific characteristics of frugivores in their effectiveness as seed dispersers.

\section{(a) Habitat}

Chelonians are a diverse group of vertebrates whose different habits, such as terrestrial, semi-aquatic, aquatic and marine, have allowed them to exploit many habitats and resources. Terrestrial plants and tortoises are perhaps the first that come to mind when thinking about seed dispersal in this group. With their preponderance of fleshy fruits, terrestrial plants could be considered more zoochorous than their aquatic counterparts, and because of their habitat, tortoises and terrestrial -or semi-aquatic- turtles are more likely to encounter fruits and disperse their seeds within terrestrial habitats. However, as we found, seed dispersal is also carried out by mainly aquatic species, both on land and in water, for terrestrial and aquatic plants, and even for coastal and marine plants in marine ecosystems. Yet, most studies of chelonian FSD have focused on terrestrial chelonians andlargely ignored the role of aquatic and marine species in seed dispersal (Moll and Jansen 1995). Ultimately, the habitats of both chelonians and of the plants they encounter will determine which fruits are available to each species, and whereto the seeds can be dispersed.

\section{(b) Size and age}

Tortoises and turtles exhibit great inter- and intraspecific size variation. Size generally increases with age in chelonians (Carr, 1952; Ernst and Lovich, 2009). From the perspective of FSD, the size of chelonians limits the size and the number of fruits 
Falcón et al. Frugivory and seed dispersal by chelonians

and/or seeds they can swallow and pass through their guts. Furthermore, size may affect gut passage time (see section on mouth and gut passage treatment) and volume of the scat. Thus, size is expected to substantially affect the ability and effectiveness of chelonians as seed dispersers (see also section on chelonians as megafaunal seed dispersers).

Ontogenetic changes in diet may also occur in chelonians, with vegetation becoming more important as chelonians age and become larger (Moll, 1976); this seems to be common in omnivorous turtles (Clark \& Gibbons, 1969; Georges, 1982; Hart, 1983; Sung, Hau, \& Karraker, 2016). In the case of the omnivorous red sidenecked turtle (Rhinemys (Phrynops) rufipes), de Lima et al. (1997) found that most of the scat volume was palm seeds, and that the frequency of palm seeds increased with turtle size. These ontogenetic changes in diet may be accompanied by changes in gut morphology, as found in the green sea turtle (Chelonia mydas), with the ratio of long to short intestines increasing from 0.45 in post-hatchlings to 2.5 in adults, possibly reflecting a higher proportion of animal matter in the diets of young individuals (Davenport, Antipas, \& Blake, 1989).

(c) Sex

Sexual dimorphism is common in chelonians, but the direction of sexual dimorphism depends on the species and even on habitat. For example, males of angulate tortoises (Chersina angulata) are larger than females, whereas females of leopard tortoises (Stigmochelys pardalis) are larger than males within the same habitat (Mason et al., 2000). In the case of Aldabra giant tortoises (Aldabrachelys gigantea), the population exhibits no sexual dimorphism on the east of Aldabra Atoll, but males 
Falcón et al. Frugivory and seed dispersal by chelonians

gradually attain larger sizes compared to females towards the western side of the atoll (Turnbull et al., 2015). As described above, size is expected to have a differential effect on seed dispersal, and there may thus be differences in the seed dispersal provided by males and females, respectively. For example, where sexual dimorphism is present, the larger males of Aldabra giant tortoises are able to extend their necks to reach higher vegetation and fruits than the smaller females can (WF \& DMH, pers. obs). Males and females may also exhibit different behaviours, e.g., habitat selection, which can affect the outcome of FSD. For example, most of the stomach contents of the omnivorous female smooth softshell turtle (Apalone mutica) were aquatic items, whereas stomach content of males was mostly terrestrial items and included more fruits (Plummer \& Farrar, 1981). These sexual differences in terms of diet were attributed to the different microhabitat preferences (females forage in deep water, whereas males forage in the interface between aquatic and terrestrial habitats). Furthermore, males and females of some species may show differences in home range size and displacement distances (see below). Difference in habitat selection, home range size and displacement distances are not only expected to affect the ability of chelonians to exploit fruits, but also their effectiveness as seed dispersers.

\section{(d) Cognition and behaviour}

Chelonians, as other animals, rely on cognitive processes to acquire knowledge about their environment through their senses, leading to learning and memory creation. The sensory features of fruits play an important role in attracting frugivorous birds and aid in their selection (Schaefer, Spitzer, \& Bairlein, 2008b), and 
Falcón et al. Frugivory and seed dispersal by chelonians

this is expected to be the case for chelonians as well. Sight and olfaction are the sensory faculties that aid turtles and tortoises in the recognition of food sources. Chelonians can perceive images and distinguish colours in the human-visible spectrum (Granda \& Stirling, 1965; Baylor \& Fettitplace, 1975; Schwartz, 1975; Neumeyer \& Jäger, 1985; Arnold \& Neumeyer, 1987; Ammermüller, Muller, \& Kolb, 1995; Ventura et al., 2001; Twig \& Perlman, 2004; Mathger, Litherland, \& Fritsches, 2007; Pellitteri-Rosa et al., 2010), and some have been shown to also have sensitivity to the ultraviolet spectrum (Ammermüller et al., 1998; Ventura et al., 1999; Zana et al., 2001). Additionally, chelonians have a highly developed olfactory (vomeronasal) system (Manteifel, Goncharova, \& Boyko, 1992; Murphy, Tucker, \& Fadool, 2001; Fadool, Wachiowiak, \& Brann, 2001), which they can use to detect volatile chemicals excreted by plants from long distances (King, 1996), and also to smell fruits at close range, possibly to evaluate ripeness (WF, $\mathrm{DMH}, \mathrm{DM}$, pers. obs.).

Learning and memory of frugivores has an important impact on seed dispersal, because decision-making based on previous experiences can determine which plants and which fruits are selected and consumed, and ultimately where seeds are dispersed (reviewed in John et al., 2016). A model by John et al. (2016) testing frugivores with different spatial memory skills suggested that those with longer spatial memory are able to relocate food sources more efficiently, survive longer and disperse larger amounts of seeds. The also moved less at random around the landscape, which led to differences in terms of the spatial distribution of seeds dispersed compared to animals with shorter memory. Captive red-footed tortoises (Chelonoidis carbonarius) can navigate efficiently in their environment, and they can remember spatial location of food for at least two months (Soldati, 2015). Moreover, 
Falcón et al. Frugivory and seed dispersal by chelonians

they were able to anticipate food availability over periods of $24 \mathrm{~h}$, discriminating between the quality and quantity of food, and remembering these attributes for at least 18 months. In relation to large-scale movement patterns, individuals of both Galápagos (Blake et al., 2013) and Aldabra giant tortoises (Baxter 2015) have been shown to follow the same movement patterns in different years, implying that they have a persistent spatial memory.

Chelonians may use landmarks and different stimuli to orient themselves and find suitable food sources. For example, when tested in a T-maze, sulcata tortoises (Geochelone sulcata) and leopard tortoises (Stigmochelys pardalis) could discriminate between colours and shapes, and associate these features with navigation to food sources (Janisch, 2013). Red-footed tortoises (Chelonoidis carbonarius) can navigate between known localities where fallen fruits are available at certain seasons (Josseaume, 2002). Also, fallen fruits encountered are often from foraging activity of arboreal/aerial frugivores (Moll \& Jansen, 1995), and it is thus possible that chelonians can use cues from other species to find food. This seems to be the case in in Malaysia, where painted terrapins (Batagur borneoensis) have been observed clustering in the water under a troop of leaf monkeys in trees above to eat berembang fruits (Sonneratia caseolaris, Lythraceae) that the monkeys were throwing into the water (Moll, 1980b).

By navigating the landscape based on previous experiences, chelonians can identify and exploit fruits. For example, (Legler, 1976) noted that the gulf snapping turtle (Elseya lavarackorum) in Australia exploits windfall fruits of fig trees, with large congregations of these turtles found around this resource. In addition, other aquatic species such as the black river turtle (Rhinoclemmys funerea) (Moll \& Jansen, 
Falcón et al. Frugivory and seed dispersal by chelonians

1995) and the Central American river turtle (Dermatemys mawii) (Moll, 1989) have been observed clustering and waiting in water beneath fruiting Ficus glabrata (Moraceae) trees, and the painted terrapin (Batagur (Callagur) borneoensis) displays similar clustering in the water under falling berembang fruits in Malaysian rivers (Moll, 1980b). Similarly, the Travancore tortoise in India (Indotestudo travancoria) (Bonin, Devaux, \& Dupré, 2006; Kanagavel \& Raghavan, 2012), and in Brazil, the redfooted tortoise (Chelonoidis carbonarius) (Moskovits \& Bjorndal, 1990) congregate beneath favoured fruiting trees to exploit these food resources. Notably, the tree Spondias testudinis (Anacardiaceae) was named for the yellow-footed tortoises (Chelonoidis denticulatus) (Mitchell \& Daly, 1998) that flock beneath fruiting trees to feed on the large, yellow-brown fruits (D Daly, pers. comm.). Furthermore, aquatic Antillean sliders (Trachemys decussata) in Cuba will emerge onto the land in great numbers after rains to feed on fallen jobo (Spondias lutea) and Bagá (Anona palustris, Annonaceae) fruits that have fallen from riparian trees (Barbour \& Carr, 1940). Thus, chelonians possess a landscape-scale spatial awareness of plants providing fruits.

\section{(e) Fruit preferences}

Animals rely on their ability to detect differences in food quality by using sensory adaptations, which allows them to circumvent some of the costs associated with foraging (Borges et al., 2011). Frugivores can establish and maintain preferences based on colour, odour and taste (Sorensen, 1983; Levey, 1987; Willson, Graff, \& Whelan, 1990; Willson \& Comet, 1993). As discussed above, chelonians have highly developed visual and olfactory systems, and are known to be attracted by smell and 
Falcón et al. Frugivory and seed dispersal by chelonians

colour (see Harless \& Morlock, 1979 for a review), which may lead to the establishment of preferences. Indeed, studies focusing on colour preferences in tortoises have found preferences for distinct visual stimuli. Probably the first study that explored colour preferences in chelonians was done by Grant (1960) on Texas tortoises (Gopherus berlandieri), which exhibited a strong preference for red, selecting food items dyed red after having initially rejected them (i.e., when the same food items had other colours). Subsequent studies using spur-thighed tortoises (Testudo graeca) (Pellitteri-Rosa et al., 2010), yellow-footed tortoises (Chelonoidis denticulatus) (Passos, Santo Mello, \& Young, 2014), and Aldabra giant tortoises (Aldabrachelys gigantea) (Spiezio, Leonardi, \& Regaiolli, 2017; DMH, unpublished) have shown a prevalent preference for yellow, and/or red colours. Furthermore, chelonians have been shown to discriminate between odours to identify potential mates and conspecifics (e.g., Auffenberg, 1965; Galeotti et al., 2009; Polo-Cavia, López, \& Martín, 2009), and they also use scent to find food items (Germano et al., 2014). Although chelonians are also known to discriminate shapes (Janisch, 2013), we did not find any studies examining food or fruit shapes as visual stimuli, nor did we find any studies on taste discrimination.

Plants are known to employ visual and scent cues to signal ripeness in fruits to attract seed dispersers, which use these cues to assess their nutritional value (Brady, 1987; Kalko, Herre, \& Handley, 1996; Schlumpberger, Clery, \& Barthlott, 2006; Schaefer, McGraw, \& Catoni, 2008a). Unripe fruits often have chemical compounds that make them unpalatable to seed dispersers (Sherburne, 1972; Schaefer, Schmidt, \& Winkler, 2003), who may learn to associate visual and scent cues with unpalatability. Therefore, different colour and smell preferences may 
Falcón et al. Frugivory and seed dispersal by chelonians

ultimately lead to distinct preferences for certain fruit traits. For example, many fruits are green when unripe, and yellow or red when ripe, and the ripening process is usually accompanied by the release of scents. Consequently, we can expect chelonians to have different preferences for different fruit species, be able to discern between ripe and unripe fruits, and show a preference for ripe ones, especially those that become yellow and red.

The degree to which chelonians act as valid seed dispersers rather than only as frugivores depends on the selection of fruits with viable seeds (usually ripe). Moskovits \& Bjorndal (1990) showed that the red- (C. carbonarius) and yellowfooted tortoises (C. denticulatus) preferred fruits over other food items, and preferred fruits that were predominantly red or yellow and were fragrant while rejecting unripe fruits. Chelonians have been observed smelling ripe and unripe fruits at close proximity before eating or apparently rejecting them. For example, this behaviour has often been observed in Aldabra giant tortoises (WF and DMH, pers. obs.; Fig. 1c). Similarly, the eastern box turtle (Terrapene carolina carolina) seems to be able to distinguish between ripe and unripe fruits, preferring the ripe ones (Allard, 1948). However, it should be noted that Hermann's tortoises (Testudo hermanni) consumes unripe green fruits of Ruscus aculeatus (Asparagaceae) when seasonally available (Del Vecchio et al., 2011), probably limiting their effectiveness as seed dispersers.

The only experimental study that we are aware of that simultaneously evaluated the perception of colour, olfaction and taste was by Grant (1960), studying the Texas tortoise. He proposed, based on feeding trials, that vision, olfaction, and taste, in that order, were used to by the tortoises to select food items. Thus, rather 
Falcón et al. Frugivory and seed dispersal by chelonians

than just relying on one or the other, chelonians use sight and olfaction and taste to discriminate between possible food sources (Grant, 1960; Fitch, 1965; Pellitteri-Rosa et al., 2010), and when fruits and seeds become available in their habitat, they are probably effective at finding them (Moll \& Jansen, 1995).

It is worth mentioning that, although it is often assumed that tortoises benefit from seed dispersal interactions with plants by obtaining food resources, it appears that some chelonians do not derive nutritive benefits from these interactions. For example, alligator snapping turtles (Macrochelys temminckii) eat many acorns (such as those of the willow oak, Quercos phellos), and significantly enhance their germination (Elbers et al. 2011). However, the acorns pass through the gut seemingly unscathed and unchanged, so why are they ingested by the turtles in large numbers? Are they covered by nutritious microorganisms after they have soaked in water and that benefit the turtles, or perhaps act as roughage to help grind up other ingested foods? More research is needed to determine the mechanisms by which chelonians are attracted to seemingly unnutritious fruits and/or seeds, and whether they truly present nutritional or other benefits to these reptiles.

\section{Plants eaten and dispersed by chelonians}

\section{(1) Taxonomical distribution}

Chelonians consume the fruits and/or seeds of a great number of plants, including at least 588 species belonging to 368 genera in 121 families. These plant species are distributed across the phylogenetic tree of angiosperms. These plant species occur in 
Falcón et al. Frugivory and seed dispersal by chelonians

many different habitats, with a variety of growth habits, and possess fruits and seeds with a myriad of traits (see Supplementary Materials S2 for the list of plant fruit and/or seed species consumed and/or dispersed by chelonians). Only $18 \%$ of all plant families, however, had more than 10 species whose fruits and/or seeds are consumed and/or dispersed by chelonians (Table 1), with $27 \%$ of families represented by only a single plant species.

\section{(2) Modes of dispersal}

There are two modes of chelonian seed dispersal: endozoochory (dispersal of seeds through the ingestion of fruits and/or seeds), and epizoochory (dispersal of seeds on external body parts). Of these, endozoochory is by far the most common mode, forming the majority of cases reviewed in our study. It occurs in terrestrial, aquatic, and even in marine ecosystems. During the process of endozoochory, the handling behaviour, gut treatment and location of defecation all affect the ultimate quality of seed dispersal (see below). Epizoochory is a passive way of dispersal where seeds are stuck on the external parts of the animals until they are subsequently dropped, and other than movement away from the mother plant, the fruits or seeds are not affected further. Epizoochory has only been observed in two species of chelonians. The terrestrial Aldabra giant tortoises (Aldabrachelys gigantea), which disperse the sticky seeds of Plumbago aphylla (Plumbaginaceae) that adhere to their carapaces, and secondarily disperse seeds of various plant species on their carapaces after birds defecate on them (e.g., Ficus spp., Moraceae; WF and DH, pers. obs.). In Australia, the aquatic eastern long-necked turtle (Chelodina longicollis), disperses several 
Falcón et al. Frugivory and seed dispersal by chelonians

wetland-associated plants whose seeds lodge on its carapacial algal mats (Burgin \& Renshaw, 2008).

\section{(3) Diversity of seeds}

The species diversity of seeds potentially dispersed by chelonians varies by chelonian species and/or studies. Overall, frugivorous chelonians covered in our review each potentially disperse a high diversity of seeds, with a mean of 13.0 plant species per chelonian species ( \pm 23.6 ; range: $1-123$; see Supplementary Materials $S 2$ for species dispersed), and for some chelonians fruits and seeds were major parts of their diets. For example, the Gopher tortoise (Gopherus polyphemus) disperses more than 50 species of seeds in pine savannah in the southestern USA (Birkhead, Guyer, \& Hermann, 2005). For the big-headed Amazon river turtle (Peltocephalus dumerilianus) fruits and seeds were the most diverse components in the diet, with a total of 19 species found in the stomachs, and with Aracaceae (palm) seeds as the most common ones (Pérez-Emán \& Paolillo, 1997). In the northern giant musk turtle (Staurotypus triporcatus), the large seeds of Diospyros digyna (Ebenaceae) comprised $63 \%$ of the volume of their stomach contents (Vogt \& Guzman, 1988). It should be noted that although careful studies have documented many dry-seeded species dispersed -and potentially dispersed-by chelonians (e.g., Hnatiuk, 1978; Cobo \& Andreu, 1988; Milton, 1992; Birkhead et al., 2005), there is likely an underestimation in the amount and diversity of such seed species when compared to fleshy-fruited species due to the difficulty of detection and/or identification. 
Falcón et al. Frugivory and seed dispersal by chelonians

\section{(4) Plants only/mostly dispersed by chelonians}

van der Pijl (1969) suggested that fruits dispersed by reptiles (saurochory) should be coloured, smelly, and borne near the ground or drop at maturity. Although strong FSD relationships have been documented between plants and some chelonians, there is a lack of evidence of any form of coevolution that has resulted in a chelonian seed dispersal syndrome (Herrera, 1985). As mentioned above (see section on preferences), although they may show preferences, chelonians potentially disperse fruits with a wide variety of s sizes, colours, and scents. For example, although they show preferences for certain fruits, Chelonoidis tortoises consume fruits with a variety of colours, including both fragrant and odourless ones (Moskovits, 1985; Guzmán \& Stevenson, 2008).

However, certain plants may rely disproportionally on chelonians for seed dispersal. For example, while rodents and birds destroy the seeds of Pandanus aquaticus (Pandanaceae), northern Australian snapping turtles (Elseya dentata) defecate the seeds intact (Kennett \& Russell-Smith, 1993). Similarly, European pond turtles (Emys orbicularis) disperse most of the seeds of Nymphaea alba (Nymphaceae) intact, while ducks, coots and fish destroy the seeds after gut passage (Calviño-Cancela, Ayres Fernández, \& Cordero Rivera, 2007, and references therein). Wang et al. (2011) found that red-footed tortoises (Chelonoidis carbonarius) may be an important seed disperser of Syagrus flexuosa (Arecaceae), because the seeds were often defecated undamaged but are rarely found at all in the scat of other animals. Furthermore, Moll \& Jansen (1995) suggested the black river turtle (Rhinoclemmys funerea) as an important seed disperser of Ficus glabrata (Moraceae) and Dieffenbachia longispatha (Araceae). This turtle is very abundant, practices 
Falcón et al. Frugivory and seed dispersal by chelonians

"windfall" feeding in water under riparian fig trees, and emerges on riverbanks and defecates seeds while on land along shorelines in optimal growing locations for these plants. Tortoises may also be especially important for the dispersal of largeseeded plant species on islands (Heleno et al. 2011; Blake et al. 2012; Falcón 2018), which has important implications at the ecosystem level (see section on chelonians as megafaunal seed dispersers).

Grasslands (composed of grasses and sedges) are an important food source in the diet of different terrestrial chelonians (e.g., eastern Hermann's tortoise, Testudo hermanni boettgeri) (Rozylowicz \& Popescu, 2013). In the case of Aldabra giant tortoises on Aldabra, grasslands are the most preferred habitat (Walton et al., in review), where the high grazing pressure led to the evolution of a specialised 'tortoise turf' plant community, whose seeds they disperse (Merton, Bourn, \& Hnatiuk, 1976; Hnatiuk, 1978). For the green sea turtle (Chelonia mydas) in the Great Barrier Reef (Australia), seagrass is an important dietary component and it disperses its seeds (Tol et al., 2017). The only other known seed disperser in the Great Barrier Reef is the dugong (Dugong dugon) (Tol et al., 2017), which is considered vulnerable and occurs in low numbers, so turtles may be more important in terms of quantity. Additionally, the diamondback terrapin is also known to be a seed disperser for the eelgrass (Zosteraceae), a type of seagrass, in the Lower Chesapeake Bay (Tulipani \& Lipcius, 2014).

Although chelonians do not necessarily seek for grass seeds per se (but see Kimmons and Moll, 2010, turtles may eat floating grass seeds from water surface), and rather act mainly as herbivores, grasses, sedges and seagrasses in general have traits that facilitate chelonian seed dispersal, and it could be important for the 
Falcón et al. Frugivory and seed dispersal by chelonians

maintenance of such communities (Merton et al., 1976; Hnatiuk, 1978; Tol et al., 2017). As Janzen (1984) puts it, "the foliage is the fruit", and the role of chelonians as seed dispersers in grass communities is likely to be of great importance in places where they reach high densities and levels of biomass, like in island ecosystems or in some places in Africa, especially when compared to other seed dispersers (e.g., Coe, Bourn, \& Swingland, 1979; Branch, 2008). It should be noted, however, that the sixtubercled Amazon river turtle (Podocnemis sextuberculata) seems to be a predator of Poaceae and Cyperaceae seeds in the Amazonas, which constituted $92 \%$ of their stomach volume contents (Fachín-Terán \& Vogt, 2014). In all cases, proper viability, germination and recruitment studies are necessary to determine whether effective seed dispersal occurs.

\section{Chelonian seed dispersal efficiency}

The ultimate definition of efficient animal-mediated seed dispersal is that a dispersal event results in the successful establishment of new reproducing plant individuals. This, however, is far from always the case, as different frugivore species do not provide the same dispersal services to plants. The seed dispersal effectiveness (SDE) framework (Schupp, 1993; Schupp et al., 2010) provides a way to estimate the contributions of individual dispersal agents to the overall dynamic of plant populations Essentially, it quantifies the number of seeds dispersed by a frugivore multiplied by the probability that a dispersed seed produces a new adult plant. As such, the SDE framework has two components: a quantitative and a qualitative one, which, in turn, have many variables, demographic parameters and subcomponents. 
Falcón et al. Frugivory and seed dispersal by chelonians

The SDE framework can thus be used as a valuable organising tool to study the ecological and evolutionary implications of seed dispersal. Below we discuss chelonian FSD in the context of the SDE framework.

\section{(1) Quantitative component}

The quantitative component of SDE can be reduced to the number of foraging visits a chelonian makes to a fruiting plant multiplied by the number of seeds dispersed for each visit (Schupp et al., 2010). The former can be affected, for example, by the local abundance of both plants and chelonians, and the chelonian's degree of frugivory, while the latter is influenced by the numbers of fruits and/or seeds handled per visit, handling behaviour, and body size (for body size, see section on chelonian functional traits).

\section{(a) Local biomass and density}

Perhaps the most comprehensive work to date on chelonian biomass and density is that of Iverson (1982), who argued that despite the important role that reptiles play in terms of the energetics at the ecosystem level, the study of chelonian abundance and biomass was a neglected subject. He calculated biomass of chelonians based on population density estimates, and analysed those data in terms of habit, habitat, and trophic position. He found that typical values of chelonian biomass are at least one order of magnitude higher than those of other ectotherm species. He also found indications that herbivorous chelonians, which often include fruits as part of their diet, appear to have higher biomass than omnivorous or carnivorous species. Finally, he found that annual production estimates in chelonians (with a maximum of $528 \mathrm{~kg}$ 
Falcón et al. Frugivory and seed dispersal by chelonians

$\mathrm{ha}^{-1} \mathrm{yr}^{-1}$ ) are similar to most other vertebrate groups, except for fishes; and that the maximum biomass for individual tortoise species could be as high as $586 \mathrm{~kg} \mathrm{ha}^{-1}$. In terms of density, studies have provided estimates for several species; for example, $0.15-0.31$ individuals $\mathrm{ha}^{-1}$, for the highly frugivorous yellow-footed tortoise in the Amazon (Guzmán \& Stevenson, 2008), 0.85 tortoises ha-1 for leopard tortoises and

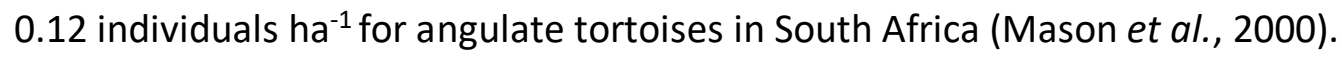
In some species, chelonian biomass may be higher than that of many classes of larger mammals. For example, Branch (2008) indicated that the leopard and angulate tortoise biomass is about $13 \%$ that of all mammalian herbivores in South Africa's Eastern Cape province, where tortoises can reach high densities (Mason et al., 2000). He posited that this meant that the total biomass of tortoises there almost equalled the combined biomass of kudu, buffalo, eland, and bushbuck, only being exceeded by that of elephants! Moreover, Coe et al. (1979) estimated the biomass of Aldabra giant tortoises to range between $253.42-353.87 \mathrm{~kg} \mathrm{ha}^{-1}$ on Aldabra Atoll, which is much higher than that exhibited by large mammalian herbivores on Africa. However, it should be noted that chelonian biomass is limited by different factors, such as habitat type (e.g., in mesic vs. xeric habitats) (McMaster \& Downs, 2006), and can differ between co-occurring species (Mason et al., 2000). Nevertheless, in general, we can expect the total numbers of seeds dispersed per hectare per year to be large for chelonians (see section on quantity of seeds dispersed), especially when considering the number of large seeds dispersed (Jerozolimski, Ribeiro, \& Martins, 2009). 
Falcón et al. Frugivory and seed dispersal by chelonians

\section{(b) Degree of frugivory}

The degree of frugivory in chelonians varies between species, and within species it can vary at the population and at the individual level. For example, in Mexican giant mud turtles (Stauratypus triporcatus), fruits and seeds were the most important dietary component across two sites in Los Tuxtlas (Mexico), but the occurrence of frugivory ranged from $38-100 \%$ between populations, and fruits and seeds represented values between $55-82 \%$ of the stomach content volume examined (Vogt \& Guzman, 1988). The degree of frugivory can also vary depending on the size of chelonians. For example, Sung et al. (2016) found a positive relationship between the size of big-headed turtles (Platysternon megacephalum) and the occurrence of fruits in their diet. Moreover, diet can vary much over short distances._Another aspect to take into consideration is the changes in diet depending on which habitat chelonians inhabit, and depending on seasons. Geoffroy's sidenecked turtle (Phrynops (Rhinemys) geoffroanus) may have different diets depending on whether it inhabits clean or polluted rivers (Medem, 1960, cited in Fachín-Terán, Vogt, \& Gomez, 1995); Souza \& Abe, 2000), and depending on season (e.g., fruits of Myrtaceae and Sapotaceae were only found in its stomach during the season of rising water levels) (Fachín-Terán et al., 1995). Likewise, the Gibba turtle (R. gibbus) has been found to feed almost exclusively on palm fruits (buriti) only during part of the year in the Rio Negro Basin in Brazil (RC Vogt, pers. comm.). Similarly, inclusion of fruits in the diet can shift seasonally in the smooth softshell turtle (Apalone mutica) (Plummer \& Farrar, 1981) and the Mexican mud turtle (Kinosternon integrum) (Macip-Rios et al., 2010). In addition, changes in diet can occur at the 
Falcón et al. Frugivory and seed dispersal by chelonians

same location (e.g., a river) over time, as the habitat and food resources change over time (e.g., river changes from clean to polluted) (Moll, 1980a).

\section{(c) Quantity of seeds dispersed}

Propagule pressure influences the establishment of plants, and the number of seeds dispersed can thus determine the dynamics of plant recruitment. Studies on chelonians indicate that tortoises and turtles are capable of dispersing a high number and diversity of seeds. For example, in the red-footed tortoise (Chelonoidis carbonarius), Wang et al. (2011) reported that a single scat sample contained high numbers of seeds, ranging from 22 to 765 seeds. Moreover, Lagler (1943) found 11,065 seeds of Nymphaea alba in the digestive tract of one individual of the common snapping turtle (Chelydra serpentina). Combining information on density estimates and information on their diet and seed dispersal ecology, Guzmán \& Stevenson (2008) estimated that yellow-footed tortoises disperse 160.70 seeds ha $^{-1}$ per year.

\section{(2) Qualitative component}

The qualitative component of SDE can be reduced to the probability that a dispersed seed survives handling by chelonians in a viable condition (quality of treatment in the mouth and gut) multiplied by the probability that a viable dispersed seed will survive, germinate, and produce a new adult (quality of deposition) (Schupp et al., 2010). 
Falcón et al. Frugivory and seed dispersal by chelonians

\section{(a) Mouth and gut passage treatment}

Lacking teeth, most chelonians tend to swallow fruits and seeds whole ("gulpers"), rather than chewing them as other vertebrate groups do (Moll \& Jansen, 1995). They use 'lingual prehension', which is the behaviour of using the tongue to touch food items to insert them into their mouths, and this is obligatory for tortoises (Wocheslander, Hilgers, \& Weisgram, 1999; Bells et al., 2008). Amphibious emydids and geoemydids use their jaws to grasp food items in terrestrial habitats, a behaviour known as 'jaw prehension' (Heiss, Plenk, \& Weisgram, 2008; Natchev et al., 2009; 2015). Moreover, and different from birds and monkeys, tortoises do not regurgitate/spit seeds. Thus, damage to seeds by the mouthparts of chelonians was minimal in the studies evaluated. For example, most of the large numbers of seeds of Nymphaea alba (Nymphaceae) found in the digestive tract of the common snapping turtle were mature, and very few of the coats were ruptured (Lagler, 1943). However, some chelonian species can damage seeds with their mouths before gut passage. For example Caputo \& Vogt (2008) reported that seeds of several plant species were never recovered whole from stomach flushing in the red side-necked turtle (Rhinemys (Phrynops) rufipes). Similarly, seeds of two species of plants were found crushed inside the stomachs of the giant South American river turtle (Podocemis expansa) (Goulding, 1980).

After consuming the fruits or seeds, they pass to the stomach and through the gut before being defecated. The overall effect on seeds can vary, depending on digestion efficiency and gut retention time (GRT; the time seeds take to pass through the guts until being defecated). Food intake rates may differ among food types in herbivorous chelonians, which have a flexible dietary response, with the ability of 
Falcón et al. Frugivory and seed dispersal by chelonians

switching between cell wall fermentation and extraction of cell contents depending on the diet (Bjorndal, 1989). Moreover, digestive efficiency is inversely related to food intake in tortoises (Meienberger, Wallis, \& Nagy, 1993). In some instances, digestive efficiency can depend on the degree of herbivory the species considered, and upon the types of fruits consumed (e.g., in the box turtles Terrapene carolina and T. ornata) (Stone \& Moll, 2009), while in others, such as yellow- and red-footed tortoises (Chelonoidis denticulatus and C. carbonarius, respectively), for a given diet, neither digestibility nor mass-specific intake varied between species, and neither did they vary by sex or body mass within each species (Bjorndal, 1989).

Chelonians seem to submit digesta to a similar degree of 'gut washing' as mammalian herbivores do (Franz et al., 2011). However, although herbivorous reptiles have similar digestibilities as mammalian herbivores (Bjorndal, 2012), overall chelonians are said to be inefficient feeders because their performance at digesting cellulose is lower when compared to mammalian herbivores, and they need to eat large quantities of food to satisfy their energy demands (Branch, 2008). As a result, plant items in their scat are often recognisable, and seeds often pass undamaged.

Compared to the other vertebrate groups, chelonians have relatively longer GRTs, with a mean of 7.65 days ( \pm 5.89 ; for all species examined combined, Fig. 3 ), due to their low metabolic rates and food intake (Stevens \& Hume, 2004; Franz et al., 2011). Gut retention times in chelonians may be affected by a myriad of factors. For example, GRT tends to vary across seasons, especially in habitats where there are wet and dry periods (e.g., Aldabrachelys gigantea) (Coe et al., 1979). Temperature also plays a role in regulating GRT, with increasing temperature leading to faster passage (Sadeghayobi et al., 2011). Moreover, GRT depends strongly on 
Falcón et al. Frugivory and seed dispersal by chelonians

fruit species consumed and on overall diet composition (Bjorndal, 1989; Stone \& Moll, 2006). For birds, secondary metabolites in fruits are known to affect GRTs (Murray et al., 1994; Wahaj et al., 1998), which is likely the case in chelonians as well. Furthermore, tortoises show variation in their intestinal morphology according to their feeding habits, and the length ratio of large to small intestines is positively related with GRT (Hailey, 1997). Also, chelonians may exhibit selective food retention based on particle size (Hatt et al., 2002), with coarser food being retained for longer (Hailey, 1997). Lastly, chelonians may exhibit antiperistalsis in the large intestine (i.e., contents are carried upwards) (Naitoh, Hukuhara, \& Kameyama, 1975), which also likely affects GRT.

Overall, mean GRT seems to increase with species size (Fig. 3), likely due to the increasing length of digestive tracts (Hatt et al., 2002). However, although mean GRT scales with body mass across different tortoise taxa, Franz et al. (2011) reported that this relationship was not significant when looking only at tortoises with body mass $>1 \mathrm{~kg}$. The reported effects of chelonian size on GRT varied by species in the studies reviewed. Body size did not influence GRT in the red-and yellow-footed tortoises (Bjorndal, 1989). When comparing GRT of hatchlings with that of adults of the aquatic Florida red-bellied turtle (Pseudemys nelsoni), Bjorndal \& Bolten (1992) reported that although adults were, on average, 250 times larger, GRT was only 1.4 longer when compared to that of hatchlings.

Potentially muddying the waters, studies on the effect of tortoise size on GRT in Galápagos and Aldabra giant tortoises that used different methods yielded different results. Sadeghayobi et al. (2011) found no effect of size on GRT of Galápagos giant tortoises (carapace width range: $0.84-1.53 \mathrm{~m}$ ) when fed artificial 
Falcón et al. Frugivory and seed dispersal by chelonians

seeds. However, Hatt et al. (2002), using $n$-alkanes particles as GRT markers, reported that mean GRT was shorter for smaller Galápagos giant tortoises (mass range: $7-38$ kg vs. $100-210 \mathrm{~kg}$ in adults). Similarly, in Aldabra giant tortoises, Falcón et al. (in revision) reported no effect of tortoise size (mass range: $0.6-104 \mathrm{~kg}$ ) on GRT (mean GRT 15 days \pm 4) when fed artificial seeds, whereas Waibel et al. (2013) reported that sub-adults ( $20-30 \mathrm{~kg}$ ) had shorter mean GRT (13 days \pm 1 ) when compared to adult individuals (75-80 kg; 18 days \pm 2 ) when fed fruits of different plants. Thus, other factors such as differences in diet, hydration, food intake and temperature may be more relevant in determining chelonian GRTs within species.

Although seed size can also affect GRT in frugivores (e.g., Fukui, 2003; Figuerola et al., 2010), this does not seem to be the case for chelonians. Braun \& Brooks (1987) found that seed size did not influence the GRT of the small, box turtle (Terrapene carolina) when fed fruits of different wild plants found in their habitat. Also, in larger chelonians such as the Chaco tortoise (Chelonoidis chilensis) (Varela \& Bucher, 2002), the Galápagos giant tortoise (Sadeghayobi et al., 2011) and the Aldabra giant tortoise (Falcón et al.in revision), seed size does not affect GRT. Overall, the GRT data suggests that within chelonian species, seeds of different sizes can be dispersed to similar distances.

\section{(b) Seed deposition}

After being consumed, fruits and seeds are processed in the gut and transported until they are eventually defecated. The state in which seeds are deposited by frugivores is affected by the combination of the mouth and gut treatments. In general, after handling and passage through chelonian guts, seeds are defecated 
Falcón et al. Frugivory and seed dispersal by chelonians

without pulp, but this can be plant-species dependent as some seeds can pass with little physical change and still be covered with pulp (Rick \& Bowman, 1961; Varela \& Bucher, 2002; Hansen, Kaiser, \& Müller, 2008; Waibel et al., 2013). Within the same species of plants, there may be differences in terms of seed damage depending on the species of chelonian that consumes them (Kimmons \& Moll, 2010).

Damage to seeds tends to be minimal after defecation. For example, Rick \& Bowman (1961) found that less than $1 \%$ of recovered seeds of Solanum cheesmaniae (Solanaceae) showed any signs of damage after gut passage. Similarly, virtually all the seeds of Solanum aldabrense were recovered intact from a single Aldabra giant tortoise scat (WF, pers. obs.). Also, painted turtles (Chrysemys picta) pass $99 \%$ of seeds intact (Padgett, Carboni, \& Schepis, 2010). In addition, 90\% of gut-passed seeds were intact for Chelonoidis carbonarius in the Pantanal (Wang et al., 2011). Moreover, most seeds were intact for after gut passage in $C$. denticulatus in the Brazilian Amazonia (Jerozolimski et al., 2009). Even for soft seeds without endocarp, like Syzygium mammilatum (Myrtaceae), substantial amounts of seeds survive gut passage undamaged (Hansen et al., 2008). As a result of the minimal damage experienced by seeds after chelonian gut passage, many of them remain viable. For example, studies reported between $90-100 \%$ of viability of seeds in the faeces of red-footed tortoises (Strong \& Fragoso, 2006; Wang et al., 2011).

The location of seed deposition, and perhaps especially the distance from the source, are two key factors for determining what happens to seeds after defecation. This is largely affected by the frugivores' movement ecology in combination with the GRTs. Only very rarely have chelonian FSD studies specifically included movement ecology (Moll \& Jansen, 1995; Strong \& Fragoso, 2006; Guzman \& Stevenson, 2008; 
Falcón et al. Frugivory and seed dispersal by chelonians

Jerozolimski et al., 2009). We therefore here include information on the movement ecology of chelonians as it affects seed deposition, germination success and ultimately plant recruitment.

Turtles and tortoises have varied home range sizes and movement distances, and these may vary depending on species and individuals within species. There is high variation of home range size between species, with the mean home range size generally increasing with species size (Fig. 4a). Overall, chelonians have a mean home range size of 14.8 ha $( \pm 24.2 ; n=41)$. There is a high within-species variation in home range size (Fig. 4a). Furthermore, chelonians show overall mean daily displacements of $103.9 \mathrm{~m} \mathrm{day}^{-1}( \pm 114.3 ; \mathrm{n}=22)$, but displacement distances do not seem to be related to chelonian size (Fig. 4b). As for home ranges, there is a high variation within species.

In contrast to many other frugivores, turtles and tortoises are mostly solitary and thus disperse seeds scattered across the landscape (Varela \& Bucher, 2002). Additionally, they often frequent areas expected to be of high recruitment probability for seeds growing into plants. For example, tortoises frequent tree gaps in forested areas to bask in the sun, and such gaps are very suitable recruitment areas for many plant species. A model parameterised with red-footed tortoise cognitive data suggested that the active use of gaps by tortoises enhances the probability of seed deposition in gaps and deforested areas (Soldati, 2015). Indeed, the congeneric yellow-footed tortoise ( $C$. denticulatus), which is a major seed disperser, often deposits seed-rich dung in open habitats and treefall gaps (Josseaume 2002, cited in Bonin et al., 2006). In the wild, yellow- and red-footed tortoises favour microsites in open areas that are important for seed germination for 
Falcón et al. Frugivory and seed dispersal by chelonians

resting, such as areas of debris piles, with fallen branches, vines or trees, where they presumably defecate more often than other sites (Moskovits \& Bjorndal, 1990;

Strong \& Fragoso, 2006). Brown wood turtles (Rhinoclemmys annulata), are also known to frequent tree gaps (Moll \& Jansen, 1995). Open areas are also often used by the gopher tortoise (Gopherus polyphemus), which are important areas of plant recruitment in pine savannah in the southestern USA (Birkhead et al., 2005). The European pond turtles, which disperses the seeds of the aquatic waterlily (Nymphaea alba, Nymphaceae), effectively disperse seeds between ponds, aiding in maintaining population connectivity and meta-population dynamics of the waterlily (Calviño-Cancela et al., 2007). Moreover, even aquatic species often spend time out of the water, increasing the probability of dispersing plants to suitable habitats (rather than in the water). For example, the black river turtle (Rhinoclemmys funerea) in Costa Rica regularly defecates on land (Jansen 1993, cited in Moll \& Jansen, 1995).

\section{(c) Seed and seedling fate}

Seed deposition after zoochory has both spatial and temporal aspects, both of which affect the ultimate fate of seeds. Spatially, the Janzen-Connell model proposed that seeds that are dispersed away from maternal plants have a higher probability of survival as they can escape distance- and density-dependent seed- and seedling predation (Janzen, 1970; Connel, 1971). Both of these are ubiquitous interactions that result in strong establishment limitations for plants (Crawley, 2000; Wright, 2002; Paine \& Harms, 2009). Temporally, Guzmán \& Stevenson (2011) proposed that escape in time via endozoochory by animals with low metabolic rates and long GRTs, 
Falcón et al. Frugivory and seed dispersal by chelonians

such as chelonians, may aid seeds by basically allowing them to 'time travel' into the future to escape from periods with high-intensity seed predation.

After being deposited in suitable habitats, viable seeds that escape predation and pathogens may eventually germinate, and a proportion of these survive and are recruited as adult plants. One of the factors that can affect germination percentage and rates of seeds consumed by chelonians is the gut treatment. For example, gut washing by the digestive fluids of frugivores may be an important mechanism which aids in increasing seed endocarp permeability, and thus enhance germination (Traveset, 1998). Germination percentage and rates can vary within plant genera and between plant species and on the frugivore species after gut passage (reviewed in Traveset, 1998). Effects on seed germination after gut passage can go from positive (enhanced germination), neutral (no effect), to negative (decreased germination). In the studies reviewed here, chelonian gut passage had a mixed effect, depending on the species of chelonian and of fruits/seeds consumed (Table 3). Compared to controls (depulped seeds), $29 \%$ of the cases, gut passage had a negative effect on germination, the effect was neutral for $39 \%$ of the cases, and in $32 \%$ of the cases, seed germination was enhanced.

In addition to depending on the species of chelonians and plants, factors such as chelonian ontogeny, seed size, within-species variation in seed dormancy, and external stimuli may affect seed germination. For example, tortoise age, which correlates with size, can affect the likelihood of seed germination after passage through the guts of Aldabra giant tortoises (Aldabrachelys gigantea), with smaller sub-adults increasing the probability of germination of some plant species when compared to larger adult tortoises, and this was attributed to the shorter GRTs of 
Falcón et al. Frugivory and seed dispersal by chelonians

sub-adults (Waibel et al., 2013). Braun \& Brooks (1987) found that after gut passage through the box turtle (Terrapene carolina), seed germination increased with increasing seed size. Plant species may also have different degrees of seed dormancy that may affect seed germination after gut passage (Rick \& Bowman, 1961). External stimuli, such as the availability of light has been shown to have a differential effect on aquatic seed germination, with delayed germination after gut passage in light conditions (but with equal total germination to controls), and delayed germination during the first year, with subsequent increased germination speed and percentage in the long term in dark conditions (Calviño-Cancela et al., 2007). The authors suggest that in their natural habitat, the differential effect of gut passage in combination with light stimuli is expected to affect seed germination in turbid vs. clear bodies of water. Similarly, we can expect that seeds inside the dung of terrestrial species, with no direct light, to have a delayed germination, as dung disintegrates, and thus escape predators in time (assuming that the dung does not attract predators).

In terms of seedling growth and vigour, the few studies we found reported a positive effect of chelonian gut passage. For example, in the case of Syzygium mammilatum (Myrtaceae), gut passage through $A$. gigantea had negative effects on seed germination rate, but positive effects on seedling growth and health when grown 'in shitu' (i.e., grown in scat) (Hansen et al., 2008). In addition, Elbers \& Moll (2011) found that common persimmon (Diospyros virginiana, Ebenaceae) and water tupelo (Nyssa aquatica, Nyssaceae) seeds had lower proportions of germinating seeds (compared to controls) after passage through the guts of alligator snapping turtles (Macrochelys temminckii), while the acorns of the willow oak (Quercus 
Falcón et al. Frugivory and seed dispersal by chelonians

phellos, Fagaceae) had a higher proportion of germination after gut passage

compared to controls. Passage of seeds of the grass Briza maxima (Poaceae) through the gut of the spur-thighed tortoise (Testudo graeca) led to seedlings growing larger and faster, although this may have been due to filtering of seed size, as only larger seeds were recorded passing through the gut (Cobo \& Andreu, 1988).

\section{(d) Secondary seed dispersal}

Secondary seed dispersal is the process by which seeds that have been initially dispersed by a frugivore via endozoochory are consumed by a second disperser, for example, through coprophagy. Some chelonian species have been observed acting as potential secondary seed dispersers. For example, giant tortoises frequently eat each other's scat on Aldabra Atoll (WF \& DMH, pers. obs.), and red- and yellow-footed tortoises (Chelonoidis carbonarius and C. denticulatus, respectively) have been observed eating tortoise scat in Brazil (Moskovits and Bjorndal 1990). Also, Young (2003), states that tortoises (without specifying which species) are partial to eating dung from camels, sheep, and goats, who themselves are potential seed dispersers (Kuiters \& Huiskes, 2010; Mancilla-Leytón, Fernández-Alés, \& Vicente, 2011; RootBernstein \& Svenning, 2016). Juvenile Central American river turtles (Dermatemys mawii) eat the scat of adults, presumably to obtain cellulolytic bacteria to aid in digestion of plant foods (Legler \& Vogt, 2013). Forsten's tortoise (Indotestudo forsteni) has been observed eating monkey scat, which contained fruit pulp (Ives et al., 2008), and thus likely also contained seeds. In addition, deer faecal pellets were found in the scat of the box turtle (Terrapene carolina bauri) (Platt et al., 2009). Although it is possible that they secondarily ingested some seeds from the deer scat, 
Falcón et al. Frugivory and seed dispersal by chelonians

the authors stated that the contribution to the overall number of seeds found in the turtle's dung is likely to be minimal. Also, North American box turtles (Terrapene carolina and T. ornata) regularly eat cow dung which often contains seeds (DM, pers. obs.)

Seeds in tortoise scat can also be potentially secondarily dispersed by nonchelonian species. For example, turtle doves (Streptopelia picturata) have been observed eating the contents of giant tortoise scat on Aldabra Atoll (WF, pers. obs). Moreover, dung beetles, which feed on scat and usually bury it, have been recorded amassing and dispersing scat of red-and yellow-footed tortoises in Brazil (Strong \& Fragoso, 2006). In addition, land crabs (Cardisoma carnifex) and coconut crabs (Birgus lastro) have been observed eating giant tortoise scat containing grass and Ficus sp. seeds on Aldabra Atoll (WF, pers. obs.). We are unaware of any studies addressing the effects of secondary seed dispersal by chelonians, or other species consuming chelonian scat, on plant germination and/or recruitment and it thus remains to be seen whether effective secondary seed dispersal occurs in, or is promoted by, chelonians.

\section{Chelonian FSD in a community context}

The interactions between plants and frugivores do not occur in a vacuum, but are embedded in the ecological network of seed dispersal interactions between all plant species and all frugivores in the community (Bascompte \& Jordano, 2007). Therefore, if we truly want to know the role of chelonians as seed dispersers, we must look at their role in a community context. Studies on the role of chelonians as 
Falcón et al. Frugivory and seed dispersal by chelonians

frugivores and seed dispersers at the community level are scarce (we found only four studies, described below) yet they provide valuable insights about their role in relation to other frugivores.

Donatti et al. (2011) studied seed dispersal interactions at the community level in the Brazilian Pantanal using bipartite interaction network analysis. For mutualistic plant-animal interactions, a bipartite network consists of nodes (vertices) and links (edges), which are represented by trophic levels (i.e., frugivores and plants in this case) and the interactions between them (interactions within trophic levels are not possible). The Pantanal seed dispersal network was hyperdiverse, with 46 species of frugivores interacting with 46 species of plants. In the network, the red-footed tortoise (Chelonoidis carbonarius), was the sixth most important frugivore in terms of the number of interactions (Fig. 5a). Given the diversity and the complexity of the network, based on the number of interactions in comparison to other frugivores and the fact that they are capable of dispersing large-seeded plants, red-footed tortoises are probably one of the most important dispersers in the Pantanal community.

Falcón (2018) studied seed dispersal interactions in the smaller plantfrugivore community of Aldabra Atoll (with ten frugivores and 37 plant species), home to Aldabra giant tortoises (Aldabrachelys gigantea). The network was highly generalised, and tortoises were the second most important seed dispersers in terms of the number of interactions. In total, $A$. gigantea dispersed the seeds of at least 20 fleshy-fruited plant species (grasses and sedges were not included; Fig. 5b), including large-seeded ones such as Cordia subcordata (Boraginaceae) and Guettarda speciosa (Rubiaceae). Moreover, he found that the network was most vulnerable to the loss 
Falcón et al. Frugivory and seed dispersal by chelonians

of three particular frugivores, one of them being the giant tortoises. This study

highlighted the importance of tortoises as megafaunal seed dispersers and suggests

that the many recently extinct giant tortoises in the Indian Ocean (see Hansen et al.

2010) had a similarly pivotal role in their communities before being exterminated.

In Galápagos, Heleno et al. (2013) used network analysis to investigate the

impact of alien plants on the seed dispersal networks in two islands, one of which

harboured giant tortoises (Chelonoidis nigrus). They looked at the seed dispersal of

both native and introduced plants by the different island frugivores. Giant tortoises

here were the third most important seed disperser in terms of the number of

interactions; Fig. 5c), and were especially important for fleshy-fruited plants. They

also performed an analysis of the quantitative seed dispersal network, and stated

that tortoises played an important role as seed dispersers based on the strength of

interactions, and that the extirpation of tortoises on other islands in the Galápagos

must have resulted in a negative impact on seed dispersal function at the community

level.

Also in the Galápagos, Nogales et al. (2017) took a step further and studied the direct contributions delivered by different groups of frugivores, including giant tortoises, lizards, and three groups of birds, to the number of seeds dispersed, and the effect on germination. Frequency of occurrence of seeds was the highest in the scats of giant tortoises and medium-sized passerine birds, but the number of seed deposited per unit area was lowest for tortoises and lizards. In terms of seed emergence after gut passage, only a small proportion of seeds from all scat samples germinated (19\%) within the study period, but those that originated from tortoise scat showed the highest emergence frequency compared to seeds dispersed by all 
Falcón et al. Frugivory and seed dispersal by chelonians

the other disperser guilds. Based on the large frequency of occurrence and number of seeds found in the scat, as well as seed germination after gut passage, they concluded that Galápagos giant tortoises play a key role as seed dispersers in the Galápagos Islands.

\section{Chelonians as megafaunal seed dispersers}

On many islands worldwide, large and giant tortoises were present until recently, and were often the largest vertebrates in their respective faunas (Hansen et al., 2010). Giant tortoises on islands function as megafauna, capable of dispersing even very large seeds (Hansen \& Galetti, 2009). Surprisingly, there is evidence that medium-sized tortoises in continental ecosystems can disperse unexpectedly large seeds. In Amazonia, (Jerozolimski et al., 2009) found that yellow-footed tortoises (Chelonoidis denticulatus), a tortoise with a mean length of $40 \mathrm{~cm}$, dispersed seeds of the palm Attalea maripa (Arecaceae) of up to $40 \times 17 \mathrm{~mm}$, and (Mitchell \& Daly, 1998) described how $C$. denticulatus tortoises easily swallowed the 50-60 $\mathrm{mm}$ large fruits of Spondias testudinis (Anacardiaceae), thus presumably capable of dispersing the ca. $40 \times 30 \mathrm{~mm}$ large seeds. The two Brazilian Chelonoidis species may thus act as some of the last surviving heirs to several of the many large-seeded fruits left orphaned by late Pleistocene megafauna extinctions (Guimarães, Galetti, \& Jordano, 2008), and Spondias mombin is thus perhaps not yet entirely "culturally deprived in [mammalian] megafauna-free forest" (sensu Janzen, 1985). 
Falcón et al. Frugivory and seed dispersal by chelonians

\section{Chelonian FSD and conservation/restoration}

Chelonians are the most endangered of the major groups of vertebrates, exceeding birds, mammals, fishes and amphibians (van Dijk et al., 2014). Factors that affect the conservation of chelonians include habitat destruction, exploitation, and climate change. On a more positive note, chelonians have shown themselves to be key players in habitat restoration projects.

\section{(1) Chelonian conservation}

Roll et al. (2017) found that the distributional overlap of the range of chelonians with protected areas is only ca. $10 \%$, which puts them at great risk, especially if they are habitat specialists. For example, the Northern Australian snapping turtle (Elseya dentata) resides in riverine habitats, and their diet consist mainly of fruits of riparian rainforest trees, so they are particularly vulnerable to changes in land management that may have negative effects on riparian forest habitats (Kennett \& Tory, 1996). Thus, habitat modification and destruction not only affect chelonian populations, but can also affect the availability of fruit resources, which can lead to the loss of seed dispersal mutualisms.

Exploitation is another factor threatening the conservation of chelonian species, and the main causes are consumption as food resources, traditional medicine, and the pet trade. Known frugivorous chelonians are not exempt from suffering from exploitation, and for example, species of the turtle genera Trachemys and Pseudemys are the most exported turtles in the USA, with individuals being taken directly from the wild, or taken from the wild and subsequently bred in captivity (Moll \& Moll, 2004; Mali et al., 2014). Similarly, species such as the radiated 
Falcón et al. Frugivory and seed dispersal by chelonians

tortoise (Astrochelys radiata) (Leuteritz, 2003) and the spur-thighed tortoise

(Testudo graeca), are prone to exploitation from their native habitat (Walker \&

Rafeliarisoa, 2012). Exploitation of chelonian populations may have important

implications for seed dispersal as the reduction of frugivore populations can result in the functional extinction of seed dispersal mutualisms, even before the species of frugivore itself goes extinct (e.g., McConkey \& Drake, 2006).

In addition, changes in temperature and precipitation due to anthropogenically-induced climate change are poised to affect many ectothermic species, including chelonians, harder than endothermic ones (Walther et al., 2002; Deutsch et al., 2008; Clusella-Trullas, Blackburn, \& Chown, 2011; Ihlow et al., 2012). For example, turtle and tortoise species may respond strongly to precipitation, and their activity and movements decrease with increasingly dry periods (Luiselli, 2005; Baxter, 2015; Falcón et al., 2018). In addition, increasing droughts can affect the habitats of chelonians (Haverkamp et al., 2017), and potentially reduce shade availability, which is an important resource for thermoregulation (Merton et al., 1976; Moulherat et al., 2014). Moreover, increasing temperatures have been shown to decrease the activity of chelonians, and they may be particularly vulnerable to increases in air temperature in terms of thermoregulation (Lambert, 1981;

McMaster \& Downs, 2013; Falcón et al., 2018). Thus, the magnitude and outcome of chelonian FSD is very likely to be negatively affected by climate change.

\section{(2) Rewilding and restoration}

Overall, because frugivorous chelonians in general are efficient seed dispersers they are ideal candidates for rewilding and restoration efforts that have the resurrection 
Falcón et al. Frugivory and seed dispersal by chelonians

of extinct seed dispersal interactions as a major focus. This is especially the case in island ecosystems, where many of the large-bodied frugivores have gone extinct (Heinen et al., 2017), and where giant tortoises are in general considered to be ecosystem engineers (Hansen et al., 2010). The best-studied example of this is the introduction of Aldabra giant tortoises to islands in the Mascarenes to restore the function left behind by the extinction of the endemic Cylindrapsis giant tortoises (Griffiths et al., 2010; Hansen et al., 2010). Here, they effectively disperse the seeds of several endemic and endangered plant species (Hansen et al., 2008; Griffiths et al., 2010), including the large-seeded Diospyros egrettarum (Ebenaceae) (Griffiths et al., 2011). Moreover, these tortoises have also been shown to have potential as seed dispersers of the huge fruits of Baobab trees (Adansonia rubrostipa, Malvaceae) in Madagascar, where giant tortoises also used to occur (Andriantsaralaza et al., 2013), and may soon find themselves being deployed as ecological restoration agents in Madagascar, too (Pedrono et al., 2017).

The perhaps most 'extreme' functional substitution can be found in Hawai'i, where recently extinct herbivorous and frugivorous giant flightless ducks and geese have been replaced by the large African spurred tortoise (Centrochelys sulcata) in the Makauwahi Cave Reserve on the island of Kauai (Burney et al., 2012). Although neither terrestrial nor fresh water chelonians ever reached Hawai'i by natural means, based on their ecology, the authors posited that the spurred tortoises could act as ecological substitutes for the extinct endemic frugivore-herbivores.

Rewilding with tortoises does not have to be necessarily limited to islands, and according to Sobral-Souza et al. (2017), the continental northern Atlantic Forest of Brazil, which is heavily defaunated and fragmented, and whose fragments are too 
Falcón et al. Frugivory and seed dispersal by chelonians

small to reintroduce large mammalian frugivores, is another potential tortoise rewilding region. Based on studies highlighting the role of yellow- and red-footed tortoises as seed dispersers, especially for large-seeded plants (Chelonoidis denticulatus and C. carbonarius, respectively), and on the success of rewilding efforts with Aldabra giant tortoises, the authors argued that introducing these Chelonoidis spp. in fragments of the northern Atlantic Forest would be a way to mitigate the negative cascading effects of defaunation. To support their argument, they employed niche modelling based on known occurrence of tortoises, and assessed food availability and conservation co-benefits, and found that fragments in the northern Atlantic Forest are suitable for these tortoises.

\section{Conclusions}

(1) Chelonian FSD is geographically and taxonomically widespread. In contrast to other major classes of frugivorous reptiles, chelonian FSD is not mainly restricted to islands. However, and different to patterns of chelonian species richness, most FSD studies in turtles and tortoises come from the south-eastern USA and northern South America. Studies on chelonian FSD in south-east Asia, where chelonian species richness peaks, are notably scarce.

(2) Likewise, chelonian FSD occurs widely across the angiosperm phylogeny, with at least one family represented in the major grades and clades. There is, however, an asymmetry of interactions, in which few plant families amass most of the unique pairwise interactions with chelonians. 
Falcón et al. Frugivory and seed dispersal by chelonians

(3) Based on the studies reviewed here, we expect frugivorous chelonians to be, in most cases, efficient seed dispersers. Not only they can consume large quantities and a high diversity of fruit and/or seed species, but also damage by the mouth parts or after passage is minimal, resulting in many viable seeds. Moreover, compared to controls, passage of seeds through chelonian guts seldom causes negative impacts on seed germination, often resulting in neutral to positive effects, and can result in high seedling vigour.

(4) Seed dispersal interactions do not occur in a vacuum, and the few studies that have investigated the role of chelonians from a community perspective have highlighted their importance in terms of not only the number and strength of interactions, but also the importance of their role as central species amongst frugivores in seed dispersal networks.

(5) Large and giant tortoises (Testudinidae) were present on many islands worldwide, and were often amongst the largest vertebrates. It is in islands, especially, where they are/were prime dispersers of large-seeded plants. Nonetheless, the capacity of large testudinid species in continental ecosystems as megafaunal seed dispersers has also been demonstrated. Therefore, chelonians can act as megafaunal seed dispersers.

(6) Finally, on the one hand, chelonians are amongst the most threatened taxa in the world. Not only they suffer from habitat loss and lack of protection, but they are also heavily exploited, and face an uncertain future due to pressures imposed by climate change. On the other hand, chelonians have a great potential to aid in the conservation of plant-frugivore mutualisms, which have vital implications 
Falcón et al. Frugivory and seed dispersal by chelonians

for ecosystem functioning, and to be used as analogue species to restore lost

interactions and functions.

\section{Acknowledgements}

We thank Dr. Yuval Itescu (Tel Aviv University) for providing us with the data on the global distribution of chelonians. Funding was provided to DMH and WF by the Swiss National Science Foundation (grant number 31003A_143940), and the Zoological Museum and the Department of Evolutionary Biology and Environmental Studies (both at the University of Zurich), for which we are thankful. DM would like to thank Missouri State University, and especially the Biology Department, for financial and other support of research he has participated in related to frugivory and seed dispersal in chelonians.

\section{References}

ALLARD, H.A. (1948) The eastern box turtle and its behavior. Journal of the Tennessee Academy of Science 23, 307-321.

Ammermüller, J., ITZHAKI, A., Weiler, R. \& PerLman, I. (1998) UV-sensitive input to horizontal cells in the turtle retina. European Journal of Neuroscience 10, 15441552.

AmmermülleR, J., MULLER, J.F. \& KolB, H. (1995) The organization of the turtle inner retina. II. Analysis of color-coded and directionally selective cells. Journal of Comparative Neurology 358, 35-62.

AMOROCHO, D.F. \& REINA, R.D. (2008) Intake passage time, digesta composition and digestibility in east Pacific green turtles (Chelonia mydas agassizii) at Gorgona National Park, Colombian Pacific. Journal of Experimental Marine Biology and Ecology 360, 117-124.

Andriantsaralaza, S., Pedrono, M., Tassin, J., Roger, E., Rakouth, B. \& Danthu, P. (2013) The role of extinct giant tortoises in the germination of extant baobab 
Falcón et al. Frugivory and seed dispersal by chelonians

Adansonia rubrostipa seeds in Madagascar. African Journal of Ecology 52, 246249.

ARNOLD, K. \& NeUMEYER, C. (1987) Wavelength discrimination in the turtle Pseudemys scripta elegans. Vision Research 27, 1501-1511.

AUfFENBERG, W. (1965) Sex and species discrimination in two sympatric South American tortoises. Copeia 1965, 335-342.

Barbour, T. \& CARR, A.F. (1940) Antillean terrapins. Mem. Mus. Comp. Zool. 54, 381413.

BASCOMPTE, J. \& JORDANO, P. (2007) Plant-animal mutualistic networks: The architecture of biodiversity. Annual Reviews of Ecology, Evolution and Systematics 38, 567-593.

BAXTER, R.P.H. (2015) Movement and activity drivers of an ecosystem engineer: Aldabrachelys gigantea on Aldabra Atoll. University of Zurich, Faculty of Science, Zurich.

BAYLOR, D.A. \& FETTITPLACE, R. (1975) Light path and photon capture in turtle photoreceptors. Journal of Physiology-London 248, 433-464.

Bells, V.L., Baussart, S., Davenport, J., Shorten, M., O'Riordan, R.M., Renous, S. \& DAVENPORT, J. (2008) Functional evolution of feeding behaviour in turtles. In Biology of turtles: From structures to strategies of life (eds W. J, G. MH \& V. BELS), pp. 189-212.

BIRKHEAD, R.D., GuYER, C. \& HeRmann, S.M. (2005) Patterns of folivory and seed ingestion by gopher tortoises (Gopherus polyphemus) in a southeastern pine savanna. The American Midland Naturalist 154, 143-151.

BJORNDAL, K.A. (1989) Flexibility of digestive responses in two generalist herbivores, the tortoises Geochelone carbonaria and Geochelone denticulata. Oecologia 78, 317-321.

BJORNDAL, K.A. (2012) Fermentation in reptiles and amphibians. In Gastrointestinal microbiology pp. 199-230. Springer Science \& Business Media, Boston.

BJORNDAL, K.A. \& BolTEN, A.B. (1992) Body size and digestive efficiency in a herbivorous freshwater turtle: Advantages of small bite size. Physiological Zoology 65, 1028-1039.

Blake, S., Wikelski, M., Cabrera, F., Guezou, A., Silva, M., Sadeghayobi, E., Yackulic, C.B. \& JARAMILLO, P. (2012) Seed dispersal by Galápagos tortoises. Journal of Biogeography 39, 1961-1972.

Blake, S., Yackulic, C.B., CABrera, F., Tapia, W., GibBS, J.P., Kümmeth, F. \& WikelSkI, M. (2013) Vegetation dynamics drive segregation by body size in Galápagos 
Falcón et al. Frugivory and seed dispersal by chelonians

tortoises migrating across altitudinal gradients. Journal of Animal Ecology 82, 310-321.

Bonin, F., DevauX, B. \& Dupré, A. (2006) Turtles of the world. JHU Press, Baltimore.

Borges, R.M., Ranganathan, Y., Krishnan, A., Ghara, M. \& Pramanik, G. (2011) When should fig fruit produce volatiles? Pattern in a ripening process. Acta Oecologica 37, 611-618.

Boyle, B., Hopkins, N., Lu, Z., Garay, J.A.R., Mozzherin, D., Rees, T., Matasci, N., NarRo, M.L., Piel, W.H., Mckay, S.J., LoWry, S., Freeland, C., Peet, R.K. \& Enquist, B.J. (2013) The taxonomic name resolution service: An online tool for automated standardization of plant names. BMC Bioinformatics 14, 16.

BRADY, C. (1987) Fruit ripening. Annual Review of Plant Physiology and Plant Molecular Biology 38, 155-178.

BRANCH, B. (2008) Tortoises, terrapins and turtles of Africa. Struik Publishers, Pretoria.

BRAUN, J. \& BRooks, G.R., JR (1987) Box turtles (Terrapene carolina) as potential agents for seed dispersal. American Midland Naturalist 117, 312.

BURGIN, S. \& RenSHAW, A. (2008) Epizoochory, algae and the Australian eastern longnecked turtle Chelodina longicollis (Shaw). The American Midland Naturalist 160, 61-68.

BuRneY, D.A., JUVIK, J.O., BuRnEY, L.P. \& DiAGNe, T. (2012) Can unwanted suburban tortoises rescue native Hawaiian plants? The tortoise, 104-115.

Byng, J.W., Smets, E., van Vugt, R., Bidault, E., Davidson, C., Kenicer, G., Chase, M.W. \& CHRISTENHUSZ, M.J.M. (2018) The phylogeny of angiosperms poster. The Global Flora 1, 4-35.

Calviño-Cancela, M., Ayres Fernández, C. \& Cordero Rivera, A. (2007) European pond turtles (Emys orbicularis) as alternative dispersers of 'water-dispersed' waterlily (Nymphaea alba). Ecoscience 14, 529-535.

CAPUTO, F.P. \& VOGT, R.C. (2008) Stomach flushing vs. fecal analysis: The example of Phrynops rufipes (Testudines: Chelidae). Copeia 2008, 301-305.

CARR, A.F. JR. (1952) Handbook of turtles: The turtles of the United States, Canada and Baja California. Comstock Publishing Associates, Cornell University Press, Ithaca.

CLARK, D.B. \& GIBBONS, J.W. (1969) Dietary shift in the turtle Pseudemys scripta (Schoepff) from youth to maturity. Copeia 1969, 704.

Clusella-Trullas, S., BlackBuRn, T.M. \& Chown, S.L. (2011) Climatic predictors of temperature performance curve parameters in ectotherms imply complex responses to climate change. American Naturalist 177, 738-751. 
Falcón et al. Frugivory and seed dispersal by chelonians

Сово, M. \& ANDREU, A.C. (1988) Seed consumption and dispersal by the spur-thighed tortoise Testudo graeca. Oikos 51, 267.

COE, M.J., BOURN, D. \& SWINGLAND, I.R. (1979) The biomass, production and carrying capacity of giant tortoises on Aldabra. Philosophical Transactions of the Royal Society of London. Series B, Biological Sciences 286, 163-176.

CONNEL, J.H. (1971) On the role of natural enemies in preventing competitive exclusion in some marine animals and rain forests trees. In Dynamics of population (eds P.J. DEN BOER \& G.R. GRADWELL), pp. 298-312. Amsterdam.

CRAWLEY, M.J. (2000) Seed predators and plant population dynamics. In Seeds: the ecology of regeneration in plant communities pp. 167-182, 2nd edition. CABI, Wallingford.

DAVENPORT, J., ANTIPAS, S. \& BLAKE, E. (1989) Observations on gut function in young green turtles Chelonia mydas L. Herpetological Journal 1, 336-342.

De LIMA, A.C., Magnusson, W.E. \& dA CostA, V.L. (1997) Diet of the turtle Phrynops rufipes in Central Amazonia. Copeia 1997, 216.

Del Vecchio, S., Burke, R.L., Rugiero, L. \& CAPUla, M. (2011) Seasonal changes in the diet of Testudo hermanni hermanni in Central Italy. Herpetologica 67, 236-249.

Deutsch, C.A., TeWksbury, J.J., Huey, R.B., Sheldon, K.S., Ghalambor, C.K., HaAk, D.C. \& MARTIN, P.R. (2008) Impacts of climate warming on terrestrial ectotherms across latitude. Proceedings of the National Academy of Sciences 105, 6668-6672.

Donatti, C.I., Guimarães, P.R., Galetti, M., Pizo, M.A., Marquittı, F.M.D. \& Dirzo, R. (2011) Analysis of a hyper-diverse seed dispersal network: Modularity and underlying mechanisms. Ecology Letters 14, 773-781.

ELBERS, J.P. \& MOLL, D. (2011) Ingestion by a freshwater turtle alters germination of bottomland hardwood seeds. Wetlands 31, 757-761.

ERNST, C.H. \& LoviCH, J.E. (2009) Turtles of the United States and Canada, 2nd edition. John Hopkins University Press, Baltimore.

EstradA, A. \& FlEMING, T.H. (eds) (1986) Frugivores and seed dispersal. Dr W. Junk Publishers, Dordrecht.

FACHÍN-Terán, A. \& Vogt, R.C. (2014) Alimentación de Podocnemis sextuberculata (Testudines: Podocnemididae) en la Reserva Mamirauá, Amazonas, Brasil. Revista Colombiana de Ciencia Animal - RECIA 6, 285-298.

FACHín-TerÁn, A., Vogt, R.C. \& Gomez, M. (1995) Food habits of an assemblage of five species of turtles in the Rio Guapore, Rondonia, Brazil. Journal of Herpetology 29, 536 . 
Falcón et al. Frugivory and seed dispersal by chelonians

FADOOL, D.A., WACHIOWIAK, M. \& BRANN, J.H. (2001) Patch-clamp analysis of voltageactivated and chemically activated currents in the vomeronasal organ of Sternotherus odoratus (stinkpot/musk turtle). Journal of Experimental Biology 204, 4199-4212.

Falcón, W., Baxter, R.H., Furrer, S., Bauert, M., Hatt, J.-M., Schaepman-Strub, G., Ozgul, A., Bunbury, N., Clauss, M. \& HAnsen, D.M. (2018) Patterns of activity and body temperature of Aldabra giant tortoises in relation to environmental temperatures. Ecology and Evolution 8, 2108-2121.

FALCóN, W. (2018) Frugivory and seed dispersal by chelonians: From individuals to communities. University of Zurich, Faculty of Science. Zurich, Switzerland.

Figuerola, J., Charalambidou, I., SANTAMARiA, L. \& Green, A.J. (2010) Internal dispersal of seeds by waterfowl: Effect of seed size on gut passage time and germination patterns. Naturwissenschaften 97, 555-565.

FITCH, A.V. (1965) Sensory cues in the feeding of the ornate box turtle. Transactions of the Kansas Academy of Science 68, 522-532.

Franz, R. \& Franz, S.E. (2009) A new fossil land tortoise in the genus Chelonoidis (Testudines: Testudinidae) from the Northern Bahamas with an osteological assessment of other Neotropical tortoises. In pp. 1-44. Florida Museum of Natural History.

Franz, R., Hummel, J., Mueller, D.W.H., Bauert, M., Hatt, J.-M. \& Clauss, M. (2011) Herbivorous reptiles and body mass: Effects on food intake, digesta retention, digestibility and gut capacity, and a comparison with mammals. Comparative Biochemistry and Physiology, Part A 158, 94-101.

FUKUI, A. (2003) Relationship between seed retention time in bird's gut and fruit characteristics. Ornithological Science 2, 41-48.

GALEOTTI, P., SACCHI, R., ROSA, D.P. \& FASOLA, M. (2009) Olfactory discrimination of species, sex, and sexual maturity by the Hermann's tortoise Testudo hermanni. Copeia 2007, 980-985.

GEORGES, A. (1982) Diet of the Australian freshwater turtle Emydura krefftii (Chelonia: Chelidae), in an unproductive lentic environment. Copeia 1982, 331-336.

Germano, J., Van Zerr, V.E., Esque, T.C., Nussear, K.E. \& Lamberski, N. (2014) Impacts of upper respiratory tract disease on olfactory behavior of the Mojave desert tortoise. Journal of Wildlife Diseases 50, 354-358.

GoULDING, M. (1980) The Fishes and the forest: Explorations in Amazonian natural history. University of California Press, Berkeley.

GrandA, A.M. \& StIRLING, C.E. (1965) Differential spectral sensitivity in the optic tectum and eye of the turtle. The Journal of General Physiology 48, 901-917. 
Falcón et al. Frugivory and seed dispersal by chelonians

GRANT, C. (1960) Differentiation of the Southwestern tortoises (genus Gopherus), with notes on their habits. Transactions of the San Diego Society of Natural History. 12, 441-448.

GriffithS, C.J., HANSEN, D.M., JONES, C.G., ZUËL, N. \& HARRIS, S. (2011) Resurrecting extinct interactions with extant substitutes. Current Biology 21, 762-765.

Griffiths, C.J., Jones, C.G., Hansen, D.M., Puttoo, M., Tatayah, R.V., Mueller, C.B. \& HARRIS, S. (2010) The use of extant non-indigenous tortoises as a restoration tool to replace extinct ecosystem engineers. Restoration Ecology 18, 1-7.

GUILLON, J.-M., GUERY, L., HULIN, V. \& GIRONDOT, M. (2012) A large phylogeny of turtles (Testudines) using molecular data. Contributions to Zoology 81, 147-158.

GUIMARÃES, P.R., GALETTI, M. \& JORDANO, P. (2008) Seed dispersal anachronisms: Rethinking the fruits extinct megafauna ate. PLOS ONE 3, e1745.

GuZmAN, A. \& SteVEnson, P.R. (2008) Seed dispersal, habitat selection and movement patterns in the Amazonian tortoise, Geochelone denticulata. Amphibia-Reptilia 29, 463-472.

GuZMÁN, A. \& SteVEnSON, P.R. (2008) Seed dispersal, habitat selection and movement patterns in the Amazonian tortoise, Geochelone denticulata. Amphibia-Reptilia $29,463-472$.

GuZMÁN, A. \& SteVENSON, P.R. (2011) A new hypothesis for the importance of seed dispersal in time. Revista de Biología Tropical 59, 1795-1803.

HAILEY, A. (1997) Digestive efficiency and gut morphology of omnivorous and herbivorous African tortoises. Canadian Journal of Zoology 75, 787-794.

HANSEN, D.M. \& GaletTI, M. (2009) The forgotten megafauna. Science 324, 42-43.

Hansen, D.M., Donlan, C.J., Griffiths, C.J. \& CAMPBell, K.J. (2010) Ecological history and latent conservation potential: Large and giant tortoises as a model for taxon substitutions. Ecography 33, 272-284.

HANSEN, D.M., KAISER, C.N. \& MülleR, C.B. (2008) Seed dispersal and establishment of endangered plants on oceanic islands: The Janzen-Connell model, and the use of ecological analogues. PLOS ONE 3, e2111.

Hansen, R.M., Johnson, M.K. \& VAN DeVender, T.R. (1976) Foods of the desert tortoise, Gopherus agassizii, in Arizona and Utah. Herpetologica, 247-251.

Harless, M.L. \& Morlock, H. (1979) Turtles. John Wiley \& Sons, New York.

HART, D.R. (1983) Dietary and habitat shift with size of red-eared turtles (Pseudemys scripta) in a southern Louisiana population. Herpetologica 39, 385-290. 
Falcón et al. Frugivory and seed dispersal by chelonians

Hatt, J.M., Gisler, R., Mayes, R.W., LeChner-Doll, M., Clauss, M., Liesegang, A. \& WANNER, M. (2002) The use of dosed and herbage $n$-alkanes as markers for the determination of intake, digestibility, mean retention time and diet selection in Galapagos tortoises (Geochelone nigra). Herpetological Journal 12, 45-54.

Haverkamp, P.J., Shekeine, J., de Jong, R., Schaepman, M., Turnbull, L.A., Baxter, R., Hansen, D., Bunbury, N., Fleischer Dogley, F. \& Schaepman-Strub, G. (2017) Giant tortoise habitats under increasing drought conditions on Aldabra AtollEcological indicators to monitor rainfall anomalies and related vegetation activity. Ecological Indicators 80, 354-362.

HEINEN, J.H., VAN LOON, E.E., HANSEN, D.M. \& KISSLING, W.D. (2017) Extinction-driven changes in frugivore communities on oceanic islands. Ecography 40, 1-10.

HeISS, E., PLeNK, H.J. \& WeISGRAM, J. (2008) Microanatomy of the palatal mucosa of the semiaquatic Malayan box turtle, Cuora amboinensis, and functional implications. Anatomical Record-Advances in Integrative Anatomy and Evolutionary Biology 291, 876-885.

Heleno, R., Blake, S., Jaramillo, P., Traveset, A., Vargas, P. \& Nogales, M. (2011) Frugivory and seed dispersal in the Galápagos: what is the state of the art? Integrative Zoology 6, 110-129.

Heleno, R.H., Olesen, J.M., Nogales, M., Vargas, P. \& Traveset, A. (2013) Seed dispersal networks in the Galápagos and the consequences of alien plant invasions. Proceedings of the Royal Society B-Biological Sciences 280, 20122112.

HerRera, C.M. (1985) Determinants of plant-animal coevolution: The case of mutualistic dispersal of seeds by vertebrates. Oikos 44, 132 .

HNATIUK, S.H. (1978) Plant dispersal by the Aldabran giant tortoise, Geochelone gigantea (Schweigger). Oecologia 36, 345-350.

Howe, F. \& SMALLWOOD, J. (1982) Ecology of seed dispersal. Annual Review of Ecology and Systematics 13, 201-228.

HUME, J.P. \& WiNTERS, R. (2016) Captive birds on Dutch Mauritius: Bad-tempered parrots, warty pigeons and notes on other native animals. Historical Biology 28, 812-822.

Ihlow, F., Dambach, J., Engler, J.O., Flecks, M., Hartmann, T., Nekum, S., Rajael, H. \& RÖDDER, D. (2012) On the brink of extinction? How climate change may affect global chelonian species richness and distribution. Global Change Biology 18, 1520-1530.

IVERSON, J.B. (1982) Biomass in turtle populations: A neglected subject. Oecologia 55, 69-76.

IVERSON, J.B. (1985) Lizards as Seed Dispersers? Journal of Herpetology 19, 292. 
Falcón et al. Frugivory and seed dispersal by chelonians

IVERSON, J.B. (1987) Tortoises, not dodos, and the Tambalacoque tree. Journal of Herpetology 21, 229-230.

IVES, I.E., PlatT, S.G., TASERIN, J.S., HunOWU, I., Siwu, S. \& RaInWATER, T.R. (2008) Field surveys, natural history observations, and comments on the exploitation and conservation of Indotestudo forstenii, Leucocephalon yuwonoi, and Cuora amboinensis in Sulawesi, Indonesia. Chelonian Conservation and Biology 7, 240248.

JANISCH, J. (2013) How do tortoises know where to go? University of Vienna, Vienna.

JANZEN, D.H. (1970) Herbivores and the number of tree species in tropical forests. The American Naturalist 104, 501-528.

JANZEN, D.H. (1984) Dispersal of small seeds by big herbivores - Foliage is the fruit. American Naturalist 123, 338-353.

JANZEN, D.H. (1985) Spondias mombin is culturally deprived in megafauna-free forest. Journal of Tropical Ecology 1, 131-155.

Jerozolimski, A., Ribeiro, M.B.N. \& Martins, M. (2009) Are tortoises important seed dispersers in Amazonian forests? Oecologia 161, 517-528.

John, E.A., SOldATI, F., BURMAN, O.H.P., Wilkinson, A. \& PIKE, T.W. (2016) Plant ecology meets animal cognition: Impacts of animal memory on seed dispersal. Plant Ecology 217, 1441-1456.

Jordano, P., Garcia, C., Godoy, J.A. \& GarciA-CASTANO, J.L. (2007) Differential contribution of frugivores to complex seed dispersal patterns. Proceedings of the National Academy of Sciences 104, 3278-3282.

JOSSEAUME, B. (2002) Faecal collector for field studies of digestive responses in forest tortoises. Herpetological Journal 12, 169-172.

KABIGUMILA, J. (2001) Sighting frequency and food habits of the leopard tortoise, Geochelone pardalis, in northern Tanzania. African Journal of Ecology 39, 276285.

Kalko, E., HerRe, E.A. \& HANDley, C.O. (1996) Relation of fig fruit characteristics to fruit-eating bats in the New and Old World tropics. Journal of Biogeography 23, 565-576.

KANAGAVEL, A. \& RAGHAVAN, R. (2012) Local ecological knowledge of the threatened Cochin Forest cane turtle Vijayachelys silvatica and Travancore tortoise Indotestudo travancorica from the Anamalai Hills of the Western Ghats, India. Journal of Threatened Taxa 4, 3173-3182.

KENNETT, R. \& RUSSELL-SMITH, J. (1993) Seed dispersal by freshwater turtles in northern Australia. In Herpetology in Australia: A diverse discipline (eds D. LUNNEY \& D. AYERS), pp. 69-70. Transactions of the Royal Zoological Society of NSW, Mosman. 
Falcón et al. Frugivory and seed dispersal by chelonians

KENNETT, R. \& TORY, O. (1996) Diet of two freshwater turtles, Chelodina rugosa and Elseya dentata (Testudines: Chelidae) from the wet-dry tropics of northern Australia. Copeia 1996, 409-419.

KIMmons, J.B. \& MoLL, D. (2010) Seed dispersal by red-eared sliders (Trachemys scripta elegans) and common snapping turtles (Chelydra serpentina). Chelonian Conservation and Biology 9, 289-294.

KING, G. (1996) Reptiles and herbivory. Chapman and Hall, Cape Town.

KUITERS, A.T. \& HUISKES, H.P.J. (2010) Potential of endozoochorous seed dispersal by sheep in calcareous grasslands: Correlations with seed traits. Applied Vegetation Science 13, 163-172.

LAGLER, K.F. (1943) Food habits and economic relations of the turtles of Michigan with special reference to fish management. American Midland Naturalist 29, 257.

LAMBERT, M.R.K. (1981) Temperature, activity and field sighting in the mediterranean spur-thighed or common garden tortoise Testudo graeca L. Biological Conservation 21, 39-54.

LEGLER, J. \& VOGT, R.C. (2013) The turtles of Mexico: Land and freshwater forms. University of California Press, Berkeley.

LEGLER, J.M. (1976) Feeding habits of some Australian short-necked tortoises. The Victorian Naturalist 93, 40-43.

LEGLER, J.M. (1977) Stomach flushing: A technique for chelonian dietary studies. Herpetologica, 281-284.

LEGUAT, F. (1708) A new voyage to the East-Indies by Francis Leguat and his companions. R. Bonwicke, London.

LEUTERITZ, T.E.J. (2003) Observations on diet and drinking behaviour of radiated tortoises (Geochelone radiata) in Southwest Madagascar. African Journal of Herpetology 52, 127-130.

LEVEY, D.J. (1987) Sugar-tasting ability and fFruit selection in tropical fruit-eating birds. Auk 104, 173-179.

LeVEY, D.J., SILVA, W.R. \& GAletTI, M. (eds) (2002) Seed Dispersal and Frugivory, 1st edition. CABI, New York.

LUISELLI, L. (2003) Seasonal activity patterns and diet divergence of three sympatric Afrotropical tortoise species (genus Kinixys). Contributions to Zoology 72, 1-9.

LUISELLI, L. (2005) Aspects of comparative thermal ecology of sympatric hinge-back tortoises (Kinixys homeana and Kinixys erosa) in the Niger Delta, southern Nigeria. African Journal of Ecology 43, 64-69. 
Falcón et al. Frugivory and seed dispersal by chelonians

Macip-Rios, R., Hugo Sustaita-Rodriguez, V., Barrios-Quiroz, G. \& CASAS-Andreu, G. (2010) Alimentary habits of the Mexican mud turtle (Kinosternon integrum) in Tonatico, Estado de México. Chelonian Conservation and Biology 9, 90-97.

Mali, I., VAndeWeGe, M.W., DaVIS, S.K. \& Forstner, M.R.J. (2014) Magnitude of the freshwater turtle exports from the US: Long term trends and early effects of newly implemented harvest management regimes. PLOS ONE 9.

Mancilla-Leytón, J.M., Fernández-AlÉs, R. \& Vicente, A.M. (2011) Plant-ungulate interaction: Goat gut passage effect on survival and germination of Mediterranean shrub seeds. Journal of Vegetation Science 22, 1031-1037.

MANTEIFEL, Y., GonChAROVA, N. \& BoYko, V. (1992) Chemotesting movements and chemosensory sensitivity to amino acids in the European pond turtle, Emys orbicularis L. In Chemical signals in vertebrates pp. 397-401. Springer, Boston.

MARRON, A.O. \& MOORE, J.R. (2013) Evidence of frugivory and seed dispersal in Oligocene tortoises from South Dakota. Geological Magazine 150, 1143-1149.

Mason, M.C., Kerley, G.I.H., Weatherby, C.A. \& Branch, W.R. (2000) Angulate and leopard tortoises in the Thicket Biome, Eastern Cape, South Africa: Populations and biomass estimates. African Journal of Ecology 38, 147-153.

MATHGER, L.M., LITHERLAND, L. \& FRITSCHES, K.A. (2007) An anatomical study of the visual capabilities of the green turtle, Chelonia mydas. Copeia, 169-179.

MCCONKEY, K.R. \& DRAKE, D.R. (2006) Flying foxes cease to function as seed dispersers long before they become rare. Ecology 87, 271-276.

MCMASTER, M.K. \& DoWNS, C.T. (2006) Population structure and density of leopard tortoises (Geochelone pardalis) on farmland in the Nama-Karoo. Journal of Herpetology 40, 495-502.

MCMASTER, M.K. \& DOWNS, C.T. (2013) Seasonal and daily activity patterns of leopard tortoises (Stigmochelys pardalis Bell, 1828) on farmland in the Nama-Karoo, South Africa. African Zoology 48, 72-83.

Meienberger, C., WALLIS, I.R. \& NAGY, K.A. (1993) Food-intake rate and body-mass influence transit-time and digestibility in the desert tortoise (Xerobates agassizii). Physiological Zoology 66, 847-862.

MERTON, L.F.H., BOURN, D.M. \& HNATIUK, R.J. (1976) Giant tortoise and vegetation interactions on Aldabra Atoll-Part 1: Inland. Biological Conservation 9, 293304.

MILTON, S.J. (1992) Plants eaten and dispersed by adult leopard tortoises Geochelone pardalis (Reptilia, Chelonii) in the Southern Karoo. South African Journal of Zoology 27, 45-49. 
Falcón et al. Frugivory and seed dispersal by chelonians

MITCHELL, J.D. \& DALY, D.C. (1998) The 'tortoise's caja' - a new species of Spondias (Anacardiaceae) from southwestern Amazonia. Brittonia 50, 447-451.

MoLL, D. (1976) Food and feeding strategies of the Ouachita map turtle (Graptemys pseudogeographica ouachitensis). American Midland Naturalist 96, 478.

MoLL, D. (1980a) Dirty river turtles. Natural History 89, 42-49.

MoLL, D. (1989) Food and feeding behavior of the turtle, Dermatemys mawei, in Belize. Journal of Herpetology 23, 445-447.

MolL, D. \& JANSEN, K.P. (1995) Evidence for a role in seed dispersal by two tropical herbivorous turtles. Biotropica 27, 121.

MolL, D. \& MolL, E.O. (2004) The ecology, exploitation and conservation of river turtles. Oxford University Press, New York.

MoLL, E.O. (1980b) Tuntong Laut: the river turtle that goes to sea. Nature Malaysiana 5.

MoskoviTs, D. (1985) The behaviour and ecology of the two Amazon tortoise, Geochelone carbonaria and Geochelone denticulata, in northwestern Brazil. Chicago University, Chicago.

MosKoVITS, D.K. \& BJORNDAL, K.A. (1990) Diet and food preferences of the tortoises Geochelone carbonaria and G. denticulata in northwestern Brazil. Herpetologica 46, 207-218.

Mouden, El, E.H., Slimani, T., Ben Kaddour, K., Lagarde, F., Ouhammou, A. \& Bonnet, X. (2006) Testudo graeca graeca feeding ecology in an arid and overgrazed zone in Morocco. Journal of Arid Environments 64, 422-435.

Moulherat, S., Delmas, V., Slimani, T., Mouden, El, E.H., Louzizı, T., Lagarde, F. \& BONNET, X. (2014) How far can a tortoise walk in open habitat before overheating? Implications for conservation. Journal for Nature Conservation 22, 186-192.

MuRPHY, F.A., TUCKER, K. \& FADOOL, D.A. (2001) Sexual dimorphism and developmental expression of signal-transduction machinery in the vomeronasal organ. Journal of Comparative Neurology 432, 61-74.

Murray, K.G., Russel, S., Picone, C.M., Winnett-Murray, K., Sherwood, W. \& KuhlmanN, M.L. (1994) Fruit laxatives and seed passage rates in frugivores: Consequences for plant reproductive success. Ecology 75, 989-994.

Myrrvold, N.P., Baldridge, E., Chan, B., Sivam, D., Freeman, D.L. \& Ernest, S.K.M. (2015) An amniote life-history database to perform comparative analyses with birds, mammals, and reptiles. Ecology 96, 3109-3109. 
Falcón et al. Frugivory and seed dispersal by chelonians

NAITOH, T., HUKUHARA, T. \& KAMEYAMA, H. (1975) Observations on the gastrointestinal movements of the tortoise (Geoclemys reevesii) by means of the abdominalwindow-technique. Japanese Journal of Smooth Muscle Research 11, 39-46.

Natchev, N., Heiss, E., Lemell, P., Stratev, D. \& Weisgram, J. (2009) Analysis of prey capture and food transport kinematics in two Asian box turtles, Cuora amboinensis and Cuora flavomarginata (Chelonia, Geoemydidae), with emphasis on terrestrial feeding patterns. Zoology 112, 113-127.

NatcheV, N., TZAnkov, N., Werneburg, I. \& Heiss, E. (2015) Feeding behaviour in a 'basal' tortoise provides insights on the transitional feeding mode at the dawn of modern land turtle evolution. PeerJ 3, e1172.

NeUmeYer, C. \& JÄGER, J. (1985) Spectral sensitivity of the freshwater turtle Pseudemys scripta elegans: Evidence for the filter-effect of colored oil droplets. Vision Research 25, 833-838.

Nogales, M., González-Castro, A., Rumeu, B., Traveset, A., Vargas, P., Jaramillo, P., OlESEN, J.M. \& HELENO, R.H. (2017) Contribution by vertebrates to seed dispersal effectiveness in the Galápagos Islands: A community-wide approach. Ecology 98, 2049-2058.

OLESEN, J.M. \& VALIDO, A. (2003) Lizards as pollinators and seed dispersers: An island phenomenon. Trends in Ecology \& Evolution 18, 177-181.

PADGETT, D.J., CARBONI, J.J. \& SCHEPIS, D.J. (2010) The dietary composition of Chrysemys picta picta (eastern painted turtles) with special reference to the seeds of aquatic macrophytes. Northeastern Naturalist 17, 305-312.

PAINE, C.E.T. \& HARMS, K.E. (2009) Quantifying the effects of seed arrival and environmental conditions on tropical seedling community structure. Oecologia 160, 139-150.

PAssos, L.F., SANTo Mello, H.E. \& Young, R.J. (2014) Enriching tortoises: Assessing color preference. Journal of Applied Animal Welfare Science 17, 274-281.

Pedrono, M., Andriantsaralaza, S., Griffiths, C.J., Bour, R., Besnard, G. \& Thèves, C. (2017) Ecological restoration with giant tortoises in Madagascar. ResearchGate. Https://www.researchgate.net/project/Ecological-restoration-with-gianttortoises-in-Madagascar

Pellitteri-Rosa, D., Sacchi, R., Galeotti, P., Marchesi, M. \& Fasola, M. (2010) Do Hermann's tortoises (Testudo hermanni) discriminate colours? An experiment with natural and artificial stimuli. Italian Journal of Zoology 77, 481-491.

Pérez-EmÁn, J.L. \& PAOLILlo, A. (1997) Diet of the pelomedusid turtle Peltocephalus dumerilianus in the Venezuelan Amazon. Journal of Herpetology 31, 173. 
Falcón et al. Frugivory and seed dispersal by chelonians

Platt, S.G., Elsey, R.M., Liu, H., Rainwater, T.R., Nifong, J.C., Rosenblatt, A.E., Heithaus, M.R. \& MAZzOTTI, F.J. (2013) Frugivory and seed dispersal by crocodilians: An overlooked form of saurochory? Journal of Zoology 291, 87-99.

PlATT, S.G., HALL, C., LIU, H. \& BORG, C.K. (2009) Wet-season food habits and intersexual dietary overlap of florida box turtles (Terrapene carolina bauri) on National Key Deer Wildlife Refuge, Florida. Southeastern Naturalist 8, 335-346.

Plummer, M.V. \& FARRAR, D.B. (1981) Sexual dietary differences in a population of Trionyx muticus. Journal of Herpetology 15, 175.

Polo-CAVIA, N., LóPEZ, P. \& MARTín, J. (2009) Interspecific differences in chemosensory responses of freshwater turtles: Consequences for competition between native and invasive species. Biological Invasions 11, 431-440.

R CORE TEAM (2017) R: A language and environment for statistical computing. Vienna, Austria. http://www.R-project.org.

Rezende, E.L., Lavabre, J.E., Guimarães, P.R., Jordano, P. \& Bascompte, J. (2007) Nonrandom coextinctions in phylogenetically structured mutualistic networks. Nature 448, 925-928.

RICK, C.M. \& BowmAN, R.I. (1961) Galápagos tomatoes and tortoises. Evolution 15, 407-417.

RIDLEY, H.N. (1930) The Dispersal of Plants Throughout the World. Reeve and Ashford, London.

Rodriguez-de la Rosa, R.A., Cevallos-Ferriz, S. \& Silva-Pineda, A. (1998) Paleobiological implications of Campanian coprolites. Palaeogeography, Palaeoclimatology, Palaeoecology 142, 231-254.

RoHATGI, A. (2017) WebPlotDigitizer. http://arohatgi.info/WebPlotDigitizer. Http://arohatgi.info/WebPlotDigitizer.

Roll, U., Feldman, A., Novosolov, M., Allison, A., Bauer, A.M., Bernard, R., et Al. (2017) The global distribution of tetrapods reveals a need for targeted reptile conservation. Nature Ecology \& Evolution 1, 1677-1682.

RoOt-Bernstein, M. \& SVEnNING, J.-C. (2016) Prospects for rewilding with camelids. Journal of Arid Environments 130, 54-61.

RoWE, J.W. (1992) Dietary habits of the Blanding's turtle (Emydoidea blandingi) in Northeastern Illinois. Journal of Herpetology 26, 111.

ROZYLOWICZ, L. \& POPESCU, V.D. (2013) Habitat selection and movement ecology of eastern Hermann's tortoises in a rural Romanian landscape. European Journal of Wildlife Research 59, 47-55. 
Falcón et al. Frugivory and seed dispersal by chelonians

SAdeghayobI, E., Blake, S., WiKelski, M., GibBS, J., Mackie, R. \& CABrera, F. (2011) Digesta retention time in the Galápagos tortoise (Chelonoidis nigra). Comparative Biochemistry and Physiology, Part A 160, 493-497.

SCHAEfeR, H.M., McGraW, K. \& CATONI, C. (2008a) Birds use fruit colour as honest signal of dietary antioxidant rewards. Functional Ecology 22, 303-310.

SCHAEFER, H.M., SCHMIDT, V. \& WINKLER, H. (2003) Testing the defence trade-off hypothesis: How contents of nutrients and secondary compounds affect fruit removal. Oikos 102, 318-328.

SCHAEFER, H.M., SPITZER, K. \& BAIRLEIN, F. (2008b) Long-term effects of previous experience determine nutrient discrimination abilities in birds. Frontiers in Zoology 5, 4.

SCHLUMPBerger, B.O., CleRY, R.A. \& BARTHLOTT, W. (2006) A unique cactus with scented and possibly bat-dispersed fruits: Rhipsalis juengeri. Plant Biology 8, 265-270.

SCHUPP, E.W. (1993) Quantity, quality and the effectiveness of seed dispersal by animals. In Frugivory and seed dispersal Ecological and evolutionary aspects pp. 15-29. Springer Netherlands, Dordrecht.

SCHUPP, E.W., JORDANO, P. \& GómEZ, J.M. (2010) Seed dispersal effectiveness revisited: A conceptual review. New Phytologist 188, 333-353.

SCHWARTZ, E.A. (1975) Cones excite rods in the retina of the turtle. The Journal of Physiology 246, 639-651.

SHERBURNE, J. (1972) Effects of seasonal changes in he abundance and chemistry of the fleshy fruits of northeastern woody shrubs on patterns of exploitation by frugivorous birds. Faculty of the Graduated School of Cornell University, Ithaca.

Sobral-Souza, T., Lautenschlager, L., Morcatty, T.Q., Bello, C., Hansen, D. \& Galetti, M. (2017) Rewilding defaunated Atlantic Forests with tortoises to restore lost seed dispersal functions. Perspectives in Ecology and Conservation 15, 300-307.

SOLDATI, F. (2015) Animal cognition meets ecosystem ecology: The impact of cognition on seed dispersal. University of Lincoln, Lincoln.

SORENSEN, A.E. (1983) Taste aversion and frugivore preference. Oecologia 56, 117120.

SouZA, F.L. \& ABE, A.S. (2000) Feeding ecology, density and biomass of the freshwater turtle, Phrynops geoffroanus, inhabiting a polluted urban river in south-eastern Brazil. Journal of Zoology 252, 437-446.

Spiezio, C., LeONARDI, C. \& RegaioluI, B. (2017) Assessing colour preference in Aldabra giant tortoises (Geochelone gigantea). Behavioural Processes 145, 60-64. 
Falcón et al. Frugivory and seed dispersal by chelonians

Steadman, D.W., Franz, R., Morgan, G.S., Albury, N.A., Kakuk, B., Broad, K., Franz, S.E., TINKER, K., PATEMAN, M.P., LOTT, T.A., JARZEN, D.M. \& DILCHER, D.L. (2007)

Exceptionally well preserved late Quaternary plant and vertebrate fossils from a blue hole on Abaco, The Bahamas. Proceedings of the National Academy of Sciences of the United States of America 104, 19897-19902.

SteVEns, C.E. \& Hume, I.D. (2004) Comparative Physiology of the Vertebrate Digestive System. Cambridge University Press, Cambridge.

Stone, M.D. \& MolL, D. (2006) Diet-dependent differences in digestive efficiency in two sympatric species of box turtles, Terrapene carolina and Terrapene ornata. Journal of Herpetology 40, 364-371.

StONE, M.D. \& MolL, D. (2009) Abundance and diversity of seeds in digestive tracts of Terrapene carolina and T. ornata in southwestern Missouri. The Southwestern Naturalist 54, 346-350.

StONER, K.E. \& HenRY, M. (2008) Seed dispersal and frugivory in tropical ecosystems. In Tropical biology and conservation management: Ecology (eds K. Del Claro, P.S. Oliveira, and V. Rico-Gray) pp. 176-193. Eolss Publishers Co. Ltd.

Strong, J.N. \& Fragoso, J.M.V. (2006) Seed dispersal by Geochelone carbonaria and Geochelone denticulata in northwestern Brazil. Biotropica 38, 683-686.

SUnG, Y.H., HAU, B.C.H. \& KARRAKER, N.E. (2016) Diet of the endangered big-headed turtle Platysternon megacephalum. PeerJ 2016, 10.

Svenning, J.-C., Pedersen, P.B.M., Donlan, C.J., EjRnaes, R., Faurby, S., Galetti, M., Hansen, D.M., SANDEl, B., SANDOM, C.J., Terborgh, J.W. \& Vera, F.W.M. (2016) Science for a wilder Anthropocene: Synthesis and future directions for trophic rewilding research. Proceedings of the National Academy of Sciences 113, 898906.

The Anglosperm Phylogeny Group (2016) An update of the Angiosperm Phylogeny Group classification for the orders and families of flowering plants: APG IV. Botanical Journal of the Linnean Society 181, 1-20.

TIFFNEY, B.H. (1986) Evolution of seed dispersal syndromes according to the fossil record. In Seed Dispersal (ed D.R. MURRAY), pp. 273-305. Elsevier.

TIFFNEY, B.H. (2004) Vertebrate dispersal of seed plants through time. Annual Review of Ecology, Evolution, and Systematics 35, 1-29. Annual Reviews.

Tol, S.J., JARVIS, J.C., York, P.H., GreCH, A., Congdon, B.C. \& Coles, R.G. (2017) Long distance biotic dispersal of tropical seagrass seeds by marine mega-herbivores. Scientific Reports 7. Nature Publishing Group. 
Falcón et al. Frugivory and seed dispersal by chelonians

TRAVESET, A. (1998) Effect of seed passage through vertebrate frugivores' guts on germination: A review. Perspectives in Plant Ecology, Evolution and Systematics 1, 151-190.

TULIPANI, D.C. \& LIPCIUS, R.N. (2014) Evidence of eelgrass (Zostera marina) seed dispersal by northern diamondback terrapin (Malaclemys terrapin terrapin) in lower Chesapeake Bay. PLOS ONE 9, e103346-11.

Turnibull, L.A., Ozgul, A., Accouche, W., Baxter, R., ChongSeng, L., Currie, J.C., Doak, N., Hansen, D.M., Pistorius, P., Richards, H., CROMmenaCkeR, J., Brandis, R., Fleischer DOGLEY, F. \& BUnBURY, N. (2015) Persistence of distinctive morphotypes in the native range of the CITES-listed Aldabra giant tortoise. Ecology and Evolution 5, 5499-5508.

TWIG, G. \& PERLMAN, I. (2004) Homogeneity and diversity of color-opponent horizontal cells in the turtle retina: Consequences for potential wavelength discrimination. Journal of Vision 4, 403-414.

VALIDO, A. \& OlESEN, J.M. (2007) The importance of lizards as frugivores and seed dispersers. In The importance of lizards as frugivores and seed dispersers pp. 124-147, 1st edition. CABI, Wallingford.

VAN DER PIJL, L. (1969) Principles of dispersal in higher plants. Springer-Verlag Berlin Heidelberg $\mathrm{GmbH}$, Berlin, Heidelberg.

VAN DIJK, P.P., IVERSON, J., RHODIN, A., SHAFFer, B. \& Bour, R. (2014) Turtles of the World, 7th edition: Annotated checklist of taxonomy, synonymy, distribution with maps, and conservation status. In Conservation Biology of Freshwater Turtles and Tortoises pp. 1-151. Chelonian Research Foundation.

VARelA, R.O. \& BuCheR, E.H. (2002) Seed dispersal by Chelonoidis chilensis in the Chaco dry woodland of Argentina. Journal of Herpetology 36, 137-140.

Ventura, D.F., De SouZA, J.M., DeVoe, R.D. \& ZanA, Y. (1999) UV responses in the retina of the turtle. Visual Neuroscience 16, 191-204.

VentuRA, D.F., ZANA, Y., De SOUZA, J.M. \& DeVoe, R.D. (2001) Ultraviolet colour opponency in the turtle retina. Journal of Experimental Biology 204, 2527-2534.

VoGT, R.C. \& GUZMAN, S.G. (1988) Food partitioning in a neotropical freshwater turtle community. Copeia 1988, 37.

WAHAJ, S.A., LeVEY, D.J., SANDERS, A.K. \& CipollinI, M.L. (1998) Control of gut retention time by secondary metabolites in ripe Solanum fruits. Ecology 79, 2309-2319.

Waibel, A., Griffiths, C.J., ZUel, N., SCHMid, B. \& AlBReCht, M. (2013) Does a giant tortoise taxon substitute enhance seed germination of exotic fleshy-fruited plants? Journal of Plant Ecology 6, 57-63. 
Falcón et al. Frugivory and seed dispersal by chelonians

WALKER, R.C.J. \& RAFELIARISOA, T.H. (2012) Distribution of radiated tortoise (Astrochelys radiata) bush meat poaching effort. Chelonian Conservation and Biology 11, 223-226.

Walther, G.R., Post, E., Convey, P., Menzel, A., Parmesan, C., Beebee, T., Fromentin, J.M., HOEGH-GULDBERG, O. \& BAIRLEIN, F. (2002) Ecological responses to recent climate change. Nature 416, 389-395.

Walton, R., Baxter, R., Bunbury, N., Hansen, D., Fleischer-Dogley, F., Greenwood, S. \& SCHAEPMAN-STRUB, G. (In review) In the land of giants: Habitat use and selection of the Aldabra giant tortoise on Aldabra Atoll.

Wang, E., Donatti, C.I., Ferreira, V.L., Raizer, J. \& Himmelstein, J. (2011) Food habits and notes on the biology of Chelonoidis carbonaria (Spix 1824) (Testudinidae, Chelonia) in the southern Pantanal, Brazil. South American Journal of Herpetology 6, 11-19.

WHITAKER, A.H. (2011) The roles of lizards in New Zealand plant reproductive strategies. New Zealand Journal of Botany 25, 315-328.

WICKHAM, H. (2016) ggplot2: Elegant graphics for data analysis. Springer, Houston.

WILLSON, M.F. \& COMET, T.A. (1993) Food choices by northwestern crows -

Experiments with captive, free-ranging and hand-raised birds. Condor 95, 596615.

WILLSON, M.F., GRAFF, D.A. \& WheLAN, C.J. (1990) Color preferences of frugivorous birds in relation to the colors of fleshy fruits. Condor 92, 545-555.

Wocheslander, R., Hilgers, H. \& Weisgram, J. (1999) Feeding mechanism of Testudo hermanni boettgeri (Chelonia, Cryptodira). Netherlands Journal of Zoology 49, 113.

WRIGHT, S.J. (2002) Plant diversity in tropical forests: A review of mechanisms of species coexistence. Oecologia 130, 1-14.

YounG, P. (2003) Tortoise. Reaktion Books Ltd, London.

Zana, Y., Ventura, D.F., De SouzA, J.M. \& DeVoe, R.D. (2001) Tetrachromatic input to turtle horizontal cells. Visual Neuroscience 18, 759-765.

ZWOLAK, R. (2017) How intraspecific variation in seed-dispersing animals matters for plants. Biological Reviews 93, 897-913. 


\section{Falcón et al. Frugivory and seed dispersal by chelonians}

\section{TABLES}

Table 1: Plant families of fruits and/or seeds most commonly eaten by chelonians.

\begin{tabular}{lc}
\hline \hline Family & Plant spp. \\
\hline Poaceae & 88 \\
Moraceae & 80 \\
Fabaceae & 53 \\
Arecaceae & 52 \\
Rubiaceae & 45 \\
Rosaceae & 32 \\
Myrtaceae & 31 \\
Asteraceae & 30 \\
Cyperaceae & 24 \\
Sapotaceae & 23 \\
Annonaceae & 21 \\
Polygonaceae & 20 \\
Malvaceae & 18 \\
Passifloraceae & 17 \\
Anacardiaceae & 14 \\
Cactaceae & 14 \\
Euphorbiaceae & 13 \\
Melastomataceae & 12 \\
Solanaceae & 12 \\
Nymphaceae & 11 \\
Urticaceae & 11 \\
Araceae & \\
\hline
\end{tabular}


Falcón et al. Frugivory and seed dispersal by chelonians

Table 2: Species of chelonians that engage in frugivory and/or seed dispersal.

\begin{tabular}{|c|c|c|}
\hline Family & Genus & Chelonian spp. \\
\hline Carettochelyidae & Carettochelys & 1 \\
\hline Chelidae & Chelodina & 1 \\
\hline Chelidae & Elseya & 2 \\
\hline Chelidae & Emydura & 2 \\
\hline Chelidae & Mesoclemmys & 2 \\
\hline Chelidae & Phrynops & 2 \\
\hline Cheloniidae & Chelonia & 1 \\
\hline Chelydridae & Chelydra & 1 \\
\hline Chelydridae & Macrochelys & 1 \\
\hline Dermatemydidae & Dermatemys & 1 \\
\hline Emydidae & Actinemys & 1 \\
\hline Emydidae & Chrysemys & 1 \\
\hline Emydidae & Emys & 2 \\
\hline Emydidae & Graptemys & 2 \\
\hline Emydidae & Malaclemys & 1 \\
\hline Emydidae & Terrapene & 2 \\
\hline Emydidae & Trachemys & 2 \\
\hline Geoemydidae & Batagur & 2 \\
\hline Geoemydidae & Heosemys & 1 \\
\hline Geoemydidae & Rhinoclemmys & 3 \\
\hline Geoemydidae & Vijayachelys & 1 \\
\hline Kinosternidae & Kinosternon & 5 \\
\hline Kinosternidae & Staurotypus & 1 \\
\hline Kinosternidae & Sternotherus & 1 \\
\hline Platysternidae & Platysternon & 1 \\
\hline Podocnemididae & Peltocephalus & 1 \\
\hline Podocnemididae & Podocnemis & 3 \\
\hline Testudinidae & Aldabrachelys & 1 \\
\hline Testudinidae & Astrochelys & 1 \\
\hline Testudinidae & Chelonoidis & 5 \\
\hline Testudinidae & Chersina & 1 \\
\hline Testudinidae & Gopherus & 3 \\
\hline Testudinidae & Homopus & 1 \\
\hline Testudinidae & Indotestudo & 3 \\
\hline Testudinidae & Kinixys & 1 \\
\hline Testudinidae & Psammobates & 1 \\
\hline Testudinidae & Pyxis & 1 \\
\hline Testudinidae & Stigmochelys & 1 \\
\hline Testudinidae & Testudo & 2 \\
\hline Trionychidae & Apalone & 1 \\
\hline Trionychidae & Trionyx & 1 \\
\hline
\end{tabular}


Falcón et al. Frugivory and seed dispersal by chelonians

Table 3: Effects of chelonian gut passage on the germination percent of different plant species. Effects, compared to controls, can go from positive (+) for enhanced germination, neutral $(0)$ to negative $(-)$. Chelonian species are ordered alphabetically. Treatments are depicted as gut passage (GP) and controls (C). Only control treatments of depulped seeds are considered here. See Supplementary Materials S6 for references.

\begin{tabular}{|c|c|c|c|c|c|}
\hline Chelonian species & Plant species & $\mathrm{C}(\%)$ & $\begin{array}{l}\text { GP } \\
\text { (\%) }\end{array}$ & Effect & Reference \\
\hline \multirow{8}{*}{$\begin{array}{l}\text { Aldabrachelys } \\
\text { gigantea }\end{array}$} & Adonidia merrillii & 92.0 & 94.0 & 0 & {$[1]$} \\
\hline & $\begin{array}{l}\text { Diospyros } \\
\text { egrettarum }\end{array}$ & 11.8 & 29.0 & + & {$[2]$} \\
\hline & & 12.0 & 46.0 & + & [3] \\
\hline & Adansonia fony & 52.0 & 44.3 & 0 & {$[4]$} \\
\hline & $\begin{array}{l}\text { Syzygium } \\
\text { mamillatum }\end{array}$ & 42.0 & 23.7 & - & {$[5]$} \\
\hline & Mimusops coriacea & 22.3 & 65.4 & + & [1] \\
\hline & Wikstroemia indica & 2.2 & 0.5 & 0 & [1] \\
\hline & Lantana camara & 1.9 & 6.5 & + & {$[1]$} \\
\hline \multirow[t]{2}{*}{ Chelonoidis chilensis } & Celtis pallida & 9.6 & 35.0 & + & {$[6]$} \\
\hline & Ziziphus mistol & 6.4 & 5.0 & 0 & {$[6]$} \\
\hline \multirow{6}{*}{$\begin{array}{l}\text { Chelonoidis } \\
\text { denticulata }\end{array}$} & Rauvolfia micrantha & - & - & + & [7] \\
\hline & Brosimum lactescens & - & - & - & [7] \\
\hline & Ficus sp. 1 & - & - & + & [7] \\
\hline & Ficus sp. 2 & - & - & + & [7] \\
\hline & Genipa americana & 68.3 & 62.5 & 0 & [8] \\
\hline & $\begin{array}{l}\text { Cecropia } \\
\text { sciadophylla }\end{array}$ & & & - & [7] \\
\hline \multirow[t]{5}{*}{ Chelonoidis nigra } & Opuntia echios & 2.9 & 4.3 & 0 & [9] \\
\hline & $\begin{array}{l}\text { Hippomane } \\
\text { mancinella }\end{array}$ & 7.5 & 6.0 & - & [9] \\
\hline & $\begin{array}{l}\text { Psidium } \\
\text { galapageium }\end{array}$ & 4.0 & 5.5 & 0 & [9] \\
\hline & Psidium guajava & 4.3 & 2.6 & 0 & [9] \\
\hline & Passiflora edulis & 7.8 & 4.8 & - & [9] \\
\hline Chelonoidis porteri & $\begin{array}{l}\text { Solanum } \\
\text { siparunoides }\end{array}$ & 1.0 & 81.0 & + & {$[10]$} \\
\hline \multirow[t]{3}{*}{ Chelydra serpentina } & Morus sp. & 21.6 & 19.2 & 0 & [11] \\
\hline & $\begin{array}{l}\text { Echinochloa crus- } \\
\text { galli }\end{array}$ & 32.7 & 14.4 & - & {$[11]$} \\
\hline & Rumex crispus & 66.5 & 53.0 & - & [11] \\
\hline Emys orbicularis & Nymphaea alba & 98.1 & 93.2 & 0 & [12] \\
\hline $\begin{array}{l}\text { Gopherus } \\
\text { polyphemus }\end{array}$ & Paspalum setaceum & 17.3 & 10.9 & - & {$[13]$} \\
\hline
\end{tabular}


Falcón et al. Frugivory and seed dispersal by chelonians

\begin{tabular}{|c|c|c|c|c|c|}
\hline \multirow{3}{*}{$\begin{array}{l}\text { Macrochelys } \\
\text { temminckii }\end{array}$} & Nyssa aquatica & 57.3 & 46.3 & - & [14] \\
\hline & Diospyros virginiana & 38.0 & 18.4 & - & [14] \\
\hline & Quercus phellos & 38.0 & 58.3 & + & [14] \\
\hline $\begin{array}{l}\text { Platysternon } \\
\text { megacephalum }\end{array}$ & Machilus sp. & 3.6 & 37.5 & + & [15] \\
\hline $\begin{array}{l}\text { Psammobates } \\
\text { oculifer }\end{array}$ & Grewia flavescens & 11.0 & 16.1 & 0 & [16] \\
\hline \multirow{2}{*}{$\begin{array}{l}\text { Rhinoclemmys } \\
\text { annulata }\end{array}$} & Jacaratia dolichaula & 60.0 & 50.0 & 0 & [17] \\
\hline & Faramea suerrensis & 58.3 & 66.7 & 0 & [17] \\
\hline $\begin{array}{l}\text { Rhinoclemmys } \\
\text { funerea }\end{array}$ & $\begin{array}{l}\text { Solanum } \\
\text { pimpinellifolium }\end{array}$ & 56.0 & 64.0 & 0 & [17] \\
\hline \multirow[t]{16}{*}{ Terrapene carolina } & Arisaema triphyllum & 12.0 & 40.0 & + & [18] \\
\hline & Thrinax morrisii & 19.4 & 11.8 & 0 & [19] \\
\hline & $\begin{array}{l}\text { Podophyllum } \\
\text { peltatum }\end{array}$ & 8.5 & 38.7 & + & [18] \\
\hline & & 48.9 & 87.5 & + & [20] \\
\hline & Gaylussacia baccata & 9.0 & 15.0 & 0 & [18] \\
\hline & Vaccinium vacillans & 32.4 & 37.2 & 0 & [18] \\
\hline & Byrsonima lucida & 32.3 & 14.4 & - & [19] \\
\hline & Morus alba & 92.3 & 78.3 & - & [18] \\
\hline & $\begin{array}{l}\text { Phytolacca } \\
\text { americana }\end{array}$ & 30.7 & 55.4 & + & [18] \\
\hline & Serenoa rapens & 38.9 & 79.2 & + & [19] \\
\hline & Duchesnea indica & 57.1 & 59.5 & 0 & [18] \\
\hline & Fragaria virginiana & 72.0 & 60.5 & 0 & [18] \\
\hline & Prunus serofina & 7.1 & 21.4 & + & [18] \\
\hline & Vitis aestivalis & 0.0 & 15.0 & + & [18] \\
\hline & Vitis vulpina & 6.7 & 18.5 & 0 & [18] \\
\hline & $\begin{array}{l}\text { Sambucus } \\
\text { canadensis }\end{array}$ & 20.0 & 3.4 & 0 & [18] \\
\hline \multirow[t]{5}{*}{ Testudo graeca } & Hypochaeris glabra & 92.0 & 1.0 & - & [21] \\
\hline & Spergula arvensis & 14.0 & 21.0 & + & [21] \\
\hline & Ornithophus sativus & 23.0 & 11.0 & - & [21] \\
\hline & Briza maxima & 93.3 & 82.1 & 0 & [21] \\
\hline & $\begin{array}{l}\text { Rumex } \\
\text { bucephalophorus }\end{array}$ & 55.0 & 15.7 & - & [21] \\
\hline \multirow[t]{3}{*}{ Trachemys scripta } & Morus sp. & 21.6 & 19.9 & 0 & [22] \\
\hline & $\begin{array}{l}\text { Echinochloa crus- } \\
\text { galli }\end{array}$ & 32.7 & 4.1 & - & [22] \\
\hline & Rumex crispus & 66.5 & 81.1 & - & {$[22]$} \\
\hline
\end{tabular}


bioRxiv preprint doi: https://doi org/10.1101/379933; this version posted July 30, 2018. The copyright holder for this preprint (which was not certified by peer review) is the author/funder, who has granted bioRxiv a license to display the preprint in perpetuity. It is made available under aCC-BY-NC-ND 4.0 International license.

Falcón et al. Frugivory and seed dispersal by chelonians

\section{FIGURES}
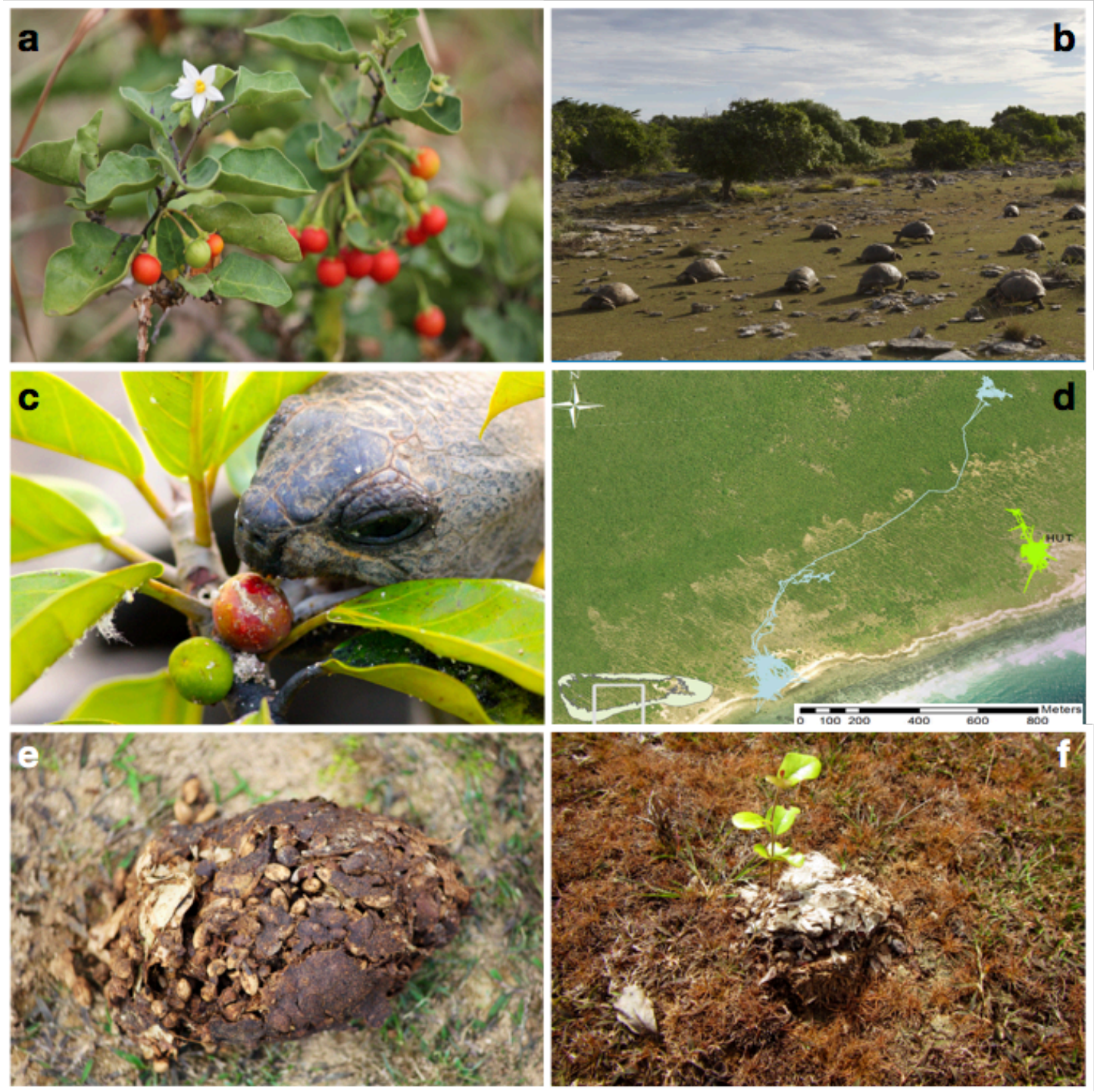

Figure 1: The process and outcome of chelonian-mediated seed dispersal, here exemplified by Aldabra giant tortoises (Aldabrachelys gigantea) on Aldabra Atoll, Seychelles. Fruiting plants like the Aldabra tomato (Solanum aldabrense) attract giant tortoises (a), which occur at high densities on the atoll (b). Fruits are a large component of the diet of giant tortoises, and they have often been observed eating ripe fruits, while ignoring green ones (e.g., of Ficus nautarum; c). After ingestion, seeds are retained for an average of 15 days in the guts of the tortoises; a time period during which tortoises can move considerable distances across the landscape (d; movement paths of two individuals on the south of the atoll). Once defecated, a single scat of giant tortoises can contain over 150 seeds, and often results in germination (e-f; seeds and a seedling of Terminalia bovinii). 


\section{Falcón et al. Frugivory and seed dispersal by chelonians}

a

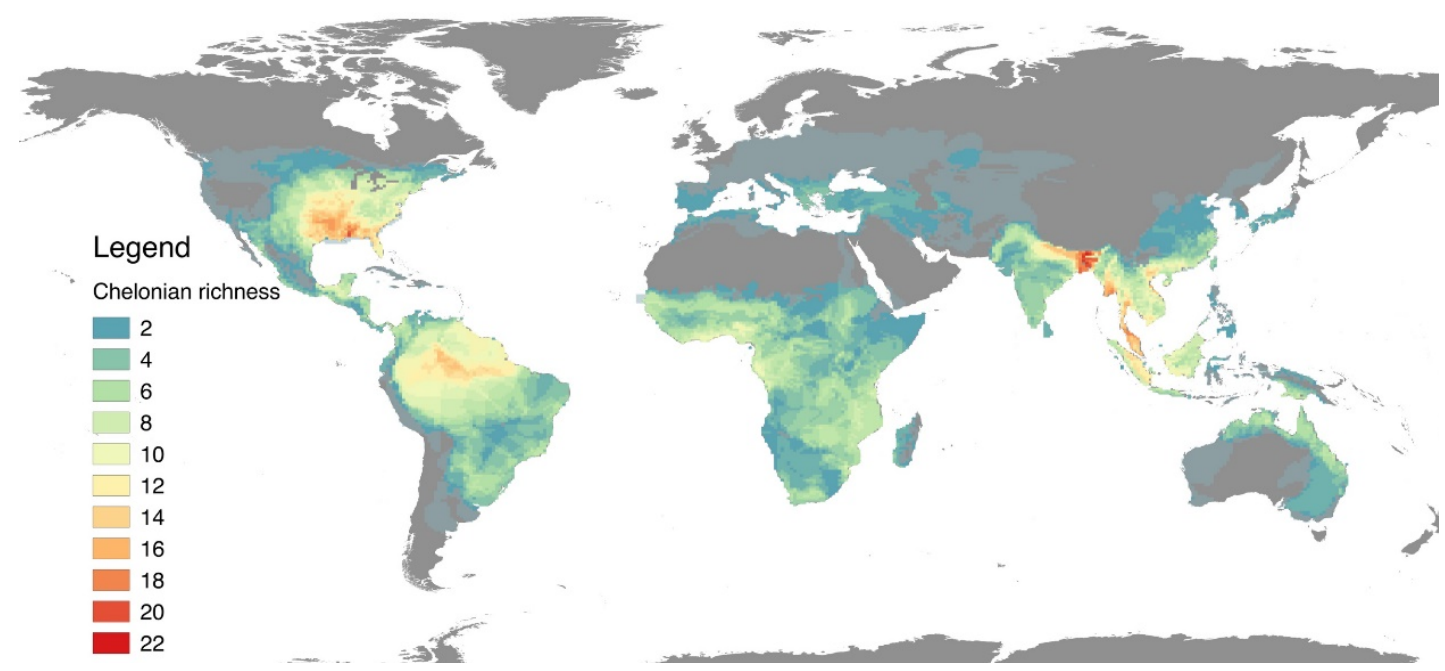

b

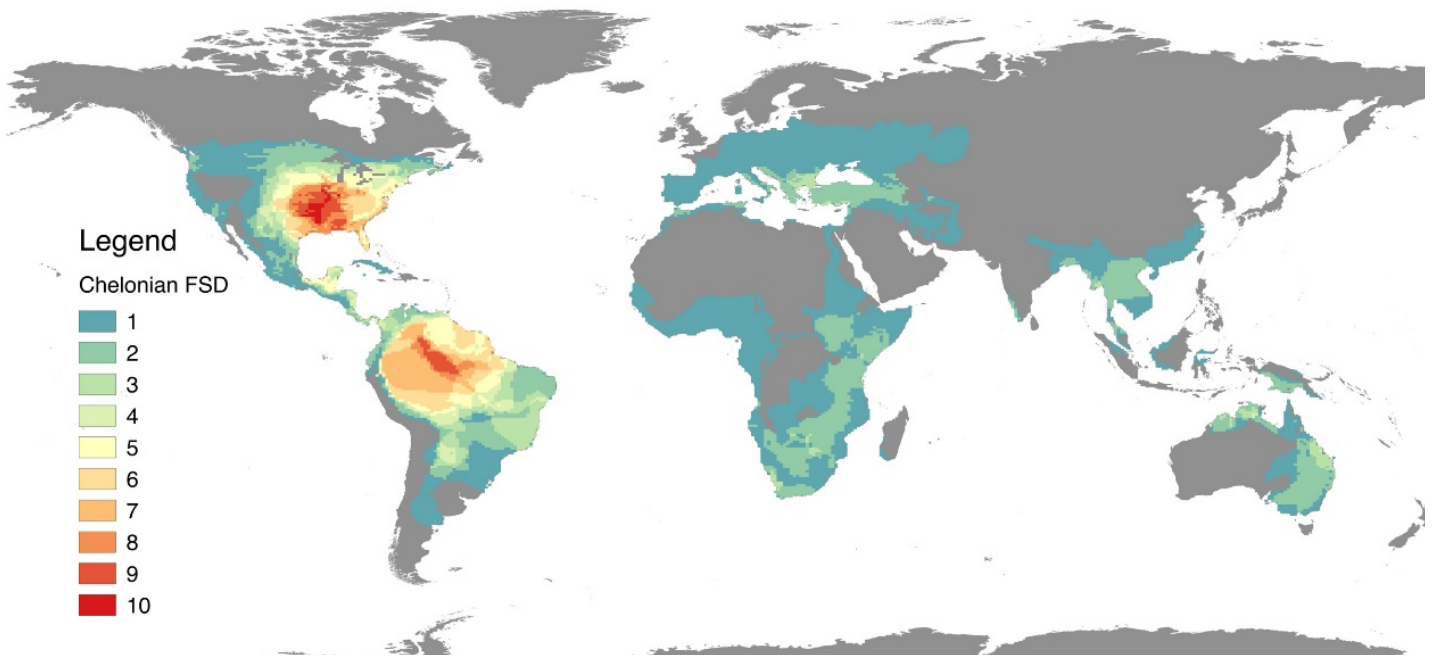

Figure 2: Overall global chelonian species richness (a), and the geographic distribution of chelonians for which we found records of frugivory and/or seed dispersal (b), excluding marine species. Note the difference in magnitude in the colour gradients of the legend. 
bioRxiv preprint doi: https://doi org/101101/379933; this version posted July 30,2018. The copyright holder for this preprint (which was not certified by peer review) is the author/funder, who has granted bioRxiv a license to display the preprint in perpetuity. It is made available under aCC-BY-NC-ND 4.0 International license.

Falcón et al. Frugivory and seed dispersal by chelonians

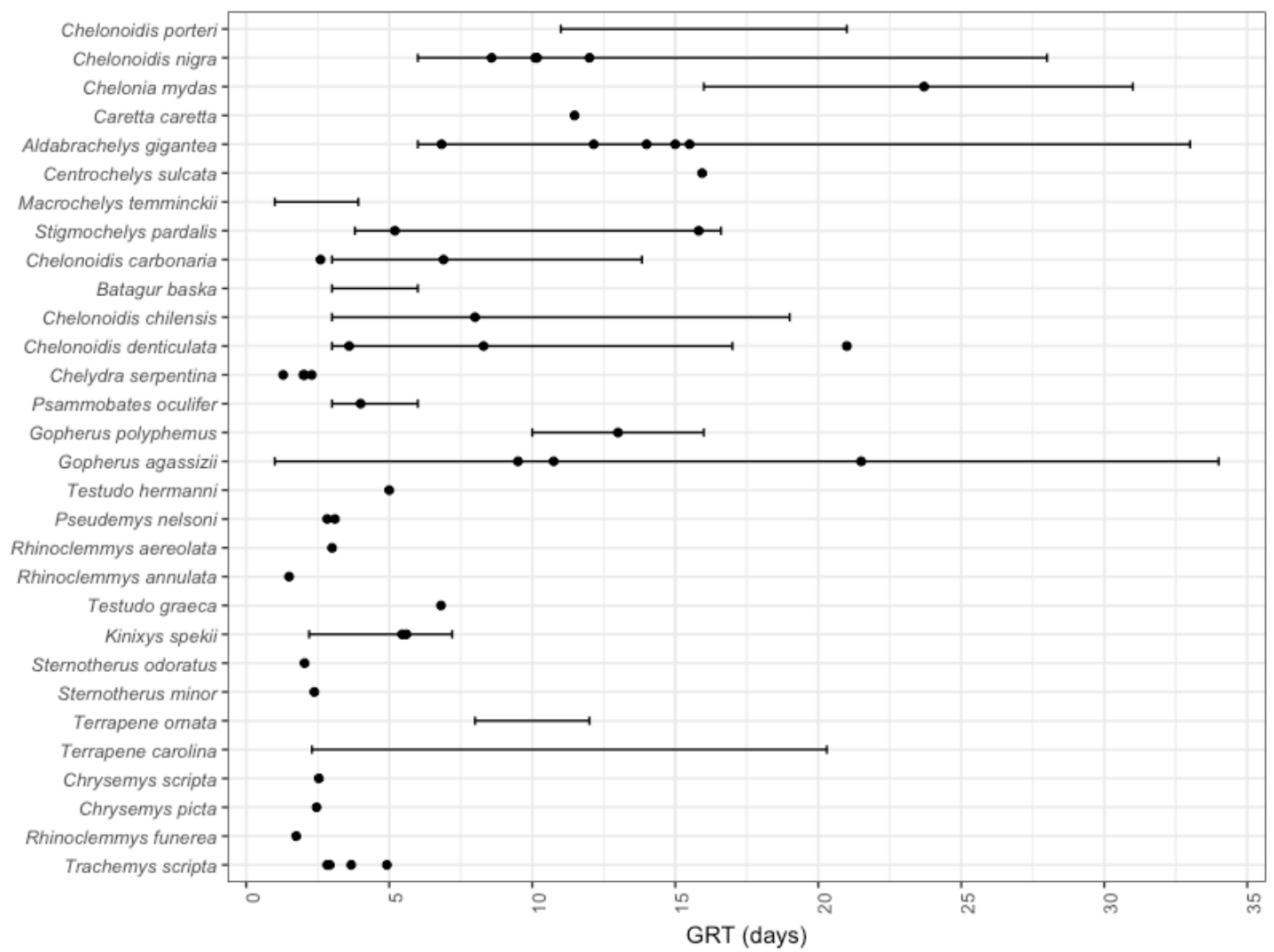

Figure 3: Gut retention times (in days) of 30 species of chelonians. Species are ordered by ascending mean body mass (bottom to top). Points represent the mean gut retention times (GRT) reported for each species by different studies, and bars represent the ranges of GRT reported (minimum and maximum). See Supplementary Materials S3 for references. 
bioRxiv preprint doi: https://doi.org/10.1101/379933; this version posted July 30,2018 . The copyright holder for this preprint (which was not certified by peer review) is the author/funder, who has granted bioRxiv a license to display the preprint in perpetuity. It is made available under aCC-BY-NC-ND 4.0 International license.

Falcón et al. Frugivory and seed dispersal by chelonians

a

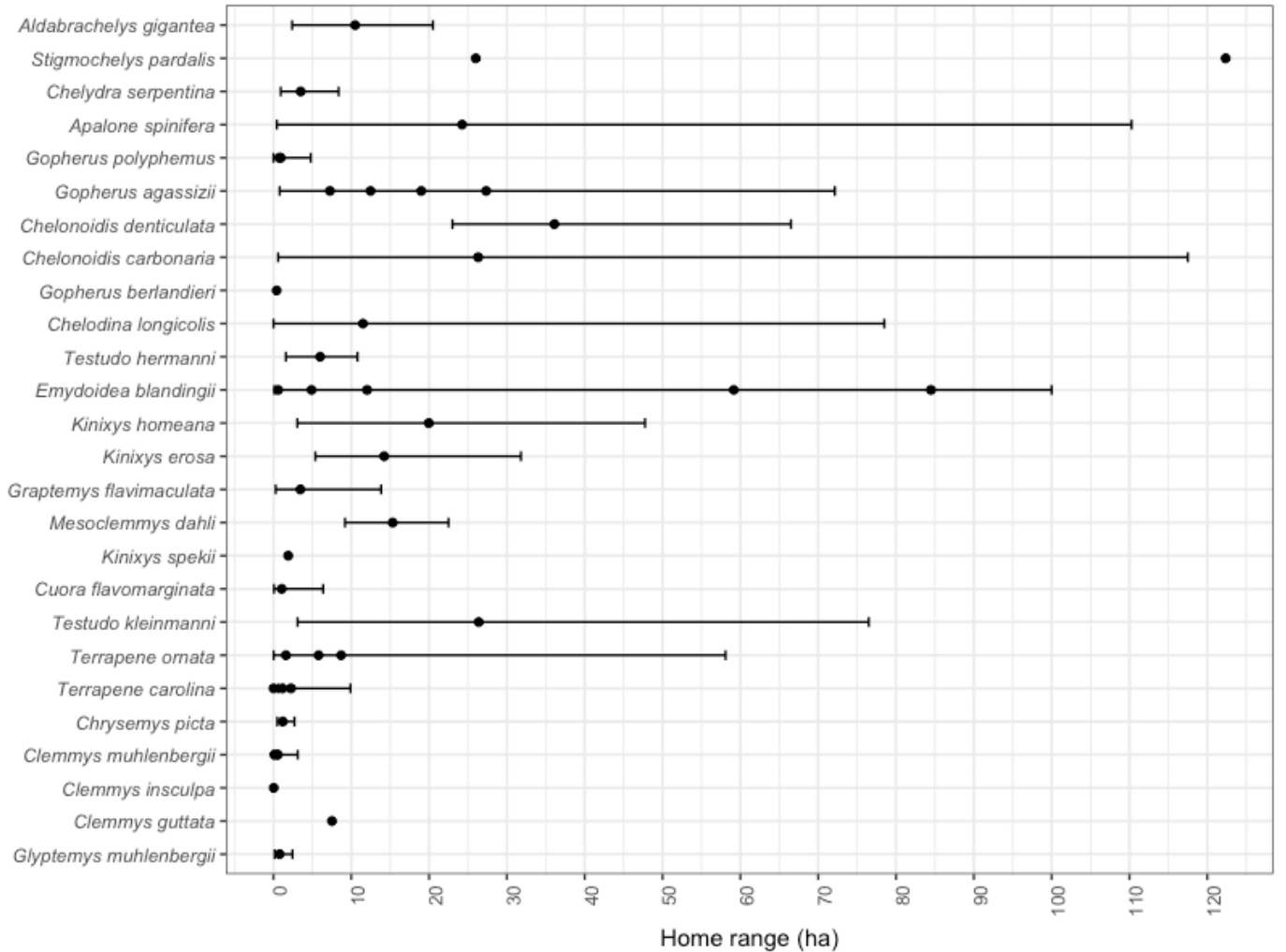

b

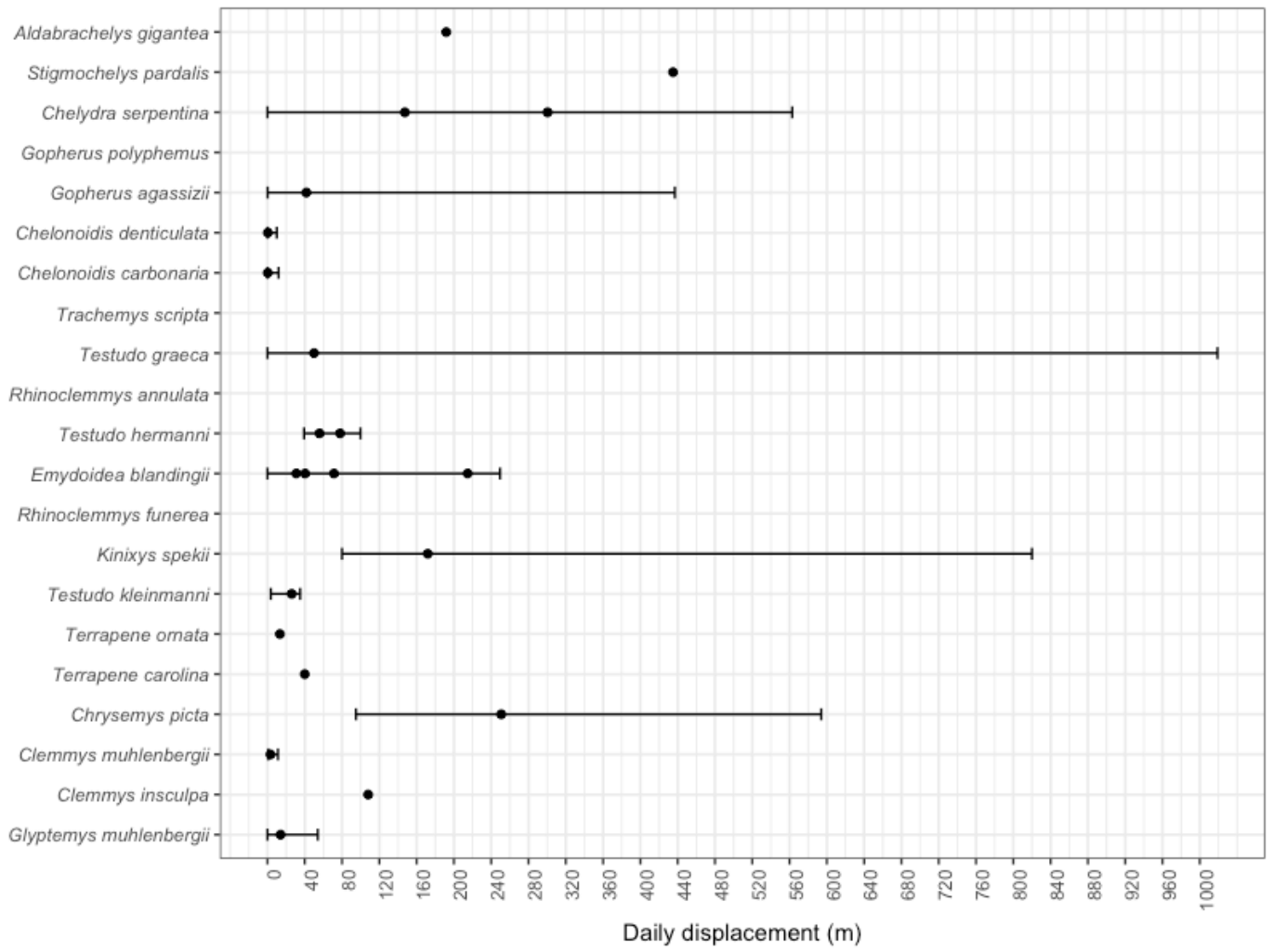

Figure 4: Home ranges (ha) and daily displacement distances ( $m$ day $^{-1}$ ) of certain species of chelonians. Points represent the mean home range and daily displacements reported for each species by different studies, and bars represent the 
bioRxiv preprint doi: https://doi.org/10.1101/379933; this version posted July 30, 2018. The copyright holder for this preprint (which was not certified by peer review) is the author/funder, who has granted bioRxiv a license to display the preprint in perpetuity. It is made available under aCC-BY-NC-ND 4.0 International license.

Falcón et al. Frugivory and seed dispersal by chelonians

reported ranges (minimum and maximum). See supplementary material S4 (a) and S5 (b) for references. 
Falcón et al. Seed dispersal by chelonians
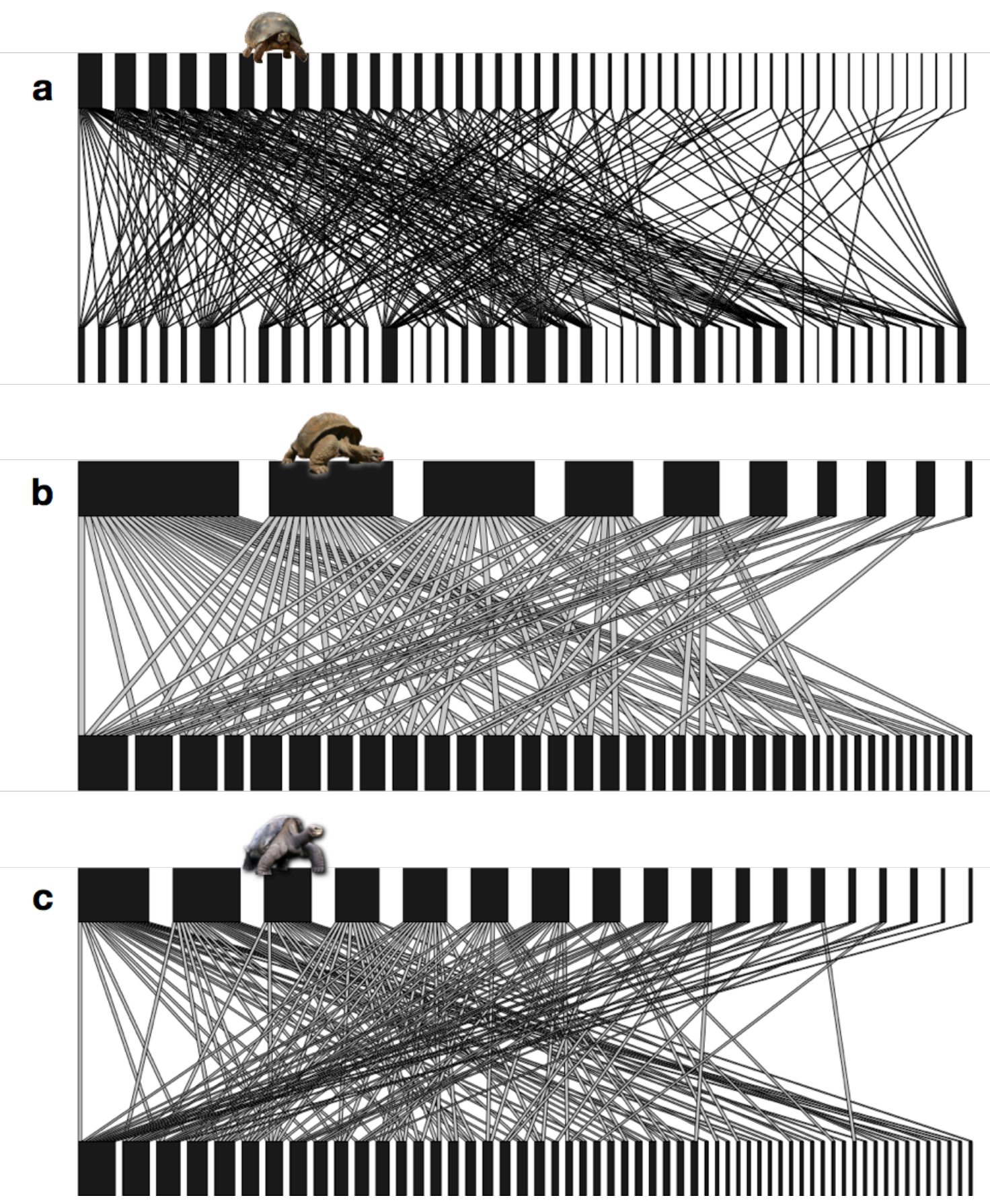

Figure 5: The role of chelonians as frugivores and seed dispersers in a community context, based on the seed dispersal networks of Pantanal (a; Chelonoidis carbonaria), Aldabra Atoll (b; Aldabrachelys gigantea), and Galápagos (c; Chelonoidis nigra). Networks are qualitative (i.e., the strength of the interactions are not considered) and the size of the boxes represent the number of interactions for each frugivore (top; organised from largest to smallest) and each plant (bottom) present in the community. Networks drawn from data available in Donatti et al. (2011; a), Falcón (2018; b), and Heleno et al. (2013; c). 


\section{SUPPLEMENTARY MATERIALS}

S1: Full references for the literature and sources of information related to chelonian frugivory and seed dispersal, gut retention times, home range and movement, and germination success reviewed in this article.

Akani, G.C., D. Capizzi, and L. Luiselli. 2001. Diet of the softshell turtle, Trionys triunguis in an Afrotropical forested region. Chelonian Conservation and Biology 4(1): 200-201

Alvarez del Toro, M. 1960. Los Reptiles de Chiapas. Instituto Zoológico del Estado, Tuxtla Gutierrez, Chiapas, Mexico.

Amorocho, D. F., \& Reina, R. D. 2008. Intake passage time, digesta composition and digestibility in East Pacific green turtles (Chelonia mydas agassizii) at Gorgona National Park, Colombian Pacific. Journal of Experimental Marine Biology and Ecology, 360(2), 117-124. http://doi.org/10.1016/j.jembe.2008.04.009

Andriantsaralaza, S., Pedrono, M., Tassin, J., Roger, E., Rakouth, B., \& Danthu, P. 2013. The role of extinct giant tortoises in the germination of extant baobab Adansonia rubrostipa seeds in Madagascar. African Journal of Ecology, 52(2), 246-249. http://doi.org/10.1111/aje.12101

Aquino Cruz, O. 2003. Hábitos alimentarios de la torguga Kinosternon herrerai Stejneger 1925, en arroyos del sureste del municipio de Xalapa, Veracruz, Mexico. Universidad Veracruzana, Fac. de Biologia-Xalapa, Mexico.

Armstrong, G., \& Booth, D. T. 2005. Dietary ecology of the Australian freshwater turtle (Elseya sp.: Chelonia: Chelidae) in the Burnett River, Queensland. Wildlife Research, 32(4), 349-353. http://doi.org/10.1071/WR04088

Arthur, K. E., M. C. Boyle, and C. J. Limpus. 2008. Ontogenetic changes in diet and habitat use in green sea turtle (Chelonia mydas) life history. Marine Ecology Progress Series 362:303-311.

Auffenberg, W., \& Weaver, W. G. 1969. Gopherus berlandieri in southeastern Texas. Bulletin of the Florida State Museum, 13(3), 141-203.

Ayres Fernández, C., Calviño-Cancela, M., \& Cordero Rivera, A. 2010. Water lilies, Nymphaea alba, in the summer diet of Emys orbicularis in northwestern Spain: Use of emergent resources. Chelonian Conservation and Biology, 9(1), 128-131. http://doi.org/10.2744/CCB-0787.1

Balensiefer, D. C., \& Vogt, R. C. 2006. Diet of Podocnemis unifilis (Testudines, Podocnemididae) during the dry season in the Mamirauá Sustainable Development Reserve, Amazonas, Brazil. Chelonian Conservation and Biology, 5(2), 312-317. http://doi.org/10.2744/10718443(2006)5[312:DOPUTP]2.0.CO;2

Barbour, T., \& Carr, A. F. 1940. Antillean terrapins. Mem. Mus. Comp. Zool., 54(4), 381-413.

Barboza, P. S. 1995. Digesta passage and functional anatomy of the digestive tract in the desert tortoise (Xerobates agassizii). Journal of Comparative Physiology B, 165(3), 193-202. http://doi.org/10.1007/BF00260810

Barret, S. L. 1990. Home range and habitat of the desert tortoise (Xerobates agassizi) in the Picacho Mountains of Arizona. Herpetologica, 46(2), 202206. 
Baxter, R. P. H. 2015. Movement and activity drivers of an ecosystem engineer: Aldabrachelys gigantea on Aldabra Atoll. University of Zurich, Faculty of Science, Zurich, Switzerland.

Bernstein, N. P., Richtsmeier, R. J., Black, R. W., \& Montgomery, B. R. 2007. Home range and philopatry in the ornate box turtle, Terrapene ornata ornata, in lowa. American Midland Naturalist, 157(1), 162-174. http://doi.org/10.1674/0003-0031(2007)157[162:HRAPIT]2.0.CO;2

Bhupathy, S. and V.S. Vijayan. 1993. Aspects of the Feeding ecology of Lissemys punctata (Testudines: Trionychidae) in Keoladeo National Park, Bharatpur, India. Hamadryad 18:13-16.

Birkhead, R. D., Guyer, C., \& Hermann, S. M. 2005. Patterns of folivory and seed ingestion by gopher tortoises (Gopherus polyphemus) in a southeastern pine savanna. The American Midland Naturalist, 154(1), 143-151. http://doi.org/10.1674/0003-0031(2005)154[0143:pofasi]2.0.co;2

Bjorndal, K. A. 1987. Digestive efficiency in a temperate herbivorous reptile, Gopherus polyphemus. Copeia, 1987(3), 714. http://doi.org/10.2307/1445664

Bjorndal, K. A. 1989. Flexibility of digestive responses in two generalist herbivores, the tortoises Geochelone carbonaria and Geochelone denticulata. Oecologia, 78(3), 317-321. http://doi.org/10.1007/BF00379104

Bjorndal, K. A., \& Bolten, A. B. 1990. Digestive processing in a herbivorous freshwater turtle: Consequences of small-intestine fermentation. Physiological Zoology, 63(6), 1232-1247. http://doi.org/10.2307/30152642?ref=search-gateway:729c1c9945761b9b98776c4d84b7846c

Bjorndal, K. A., \& Bolten, A. B. 1993. Digestive efficiencies in herbivorous and omnivorous freshwater turtles on plant diets: Do herbivores have a nutritional advantage? Physiological Zoology, 66(3), 384-395. http://doi.org/10.2307/30163699?ref=searchgateway:06cbfb387c9c49cf77350c9fe67a019c

Blake, S., Guezou, A., Deem, S. L., Yackulic, C. B., \& Cabrera, F. 2015. The dominance of introduced plant species in the diets of migratory Galápagos tortoises increases with elevation on a human-occupied island. Biotropica, 47(2), 246-258. http://doi.org/10.1111/btp.12195

Blake, S., Wikelski, M., Cabrera, F., Guezou, A., Silva, M., Sadeghayobi, E., et al. 2012. Seed dispersal by Galápagos tortoises. Journal of Biogeography, 39(11), 1961-1972. http://doi.org/10.1111/j.1365-2699.2011.02672.x

Braun, J., \& Brooks, G. R., Jr. 1987. Box turtles (Terrapene carolina) as potential agents for seed dispersal. American Midland Naturalist, $117(2), 312$. http://doi.org/10.2307/2425973

Burney, D., L. Pigott Burney, J. Jurik, M. McKenzie and R. O'Brien. 2013. Hawaiian tortoise grazing experiments hope to replicate Round Island native ecosystem restoration success. The Tortoise 1(2):128-129.

Buskirk, J.R. 1993. Yucatan box turtle Terrapene carolina yucatana. Tortuga Gazette 29(5), 1-4.

Cahn, A.R. 1937. The turtles of Illinois. Illinois Biol. Monogr. 35, 1-218.

Calviño-Cancela, M., Ayres Fernández, C., \& Cordero Rivera, A. 2007. European pond turtles (Emys orbicularis) as alternative dispersers of "waterdispersed" waterlily (Nymphaea alba), 14(4), 529-535. 
Caputo, F. P., \& Vogt, R. C. 2008. Stomach flushing vs. fecal analysis: The example of Phrynops rufipes (Testudines: Chelidae. Copeia, 2008(2), 301-305. http://doi.org/10.1643/CH-05-031

Carlson, J. E., \& Menges, E. S. 2003. Seed dispersal by Gopherus polyphemus at Archbold Biological Station, Florida. Florida Scientist, 147-154.

Carr, J., and R. Mast. 1988. Natural history observations of Kinosternon herrerai (Testudines: Kinosternidae. Trianea (Act. Ceint. Yecn. Inderena), 1:8797.

Carter, S. L., Haas, C. A., \& Mitchell, J. C. 1999. Home range and habitat selection of bog turtles in southwestern Virginia. Journal of Wildlife Management, 63(3), 853-860.

Chase, J. D., Dixon, K. R., Gates, J. E., Jacobs, D., \& Taylor, G. J. 1989. Habitat characteristics, population-size, and home range of the bog turtle, Clemmys muhlenbergii, in Maryland. Journal of Herpetology, 23(4), 356-362.

Cobo, M., \& Andreu, A. C. 1988. Seed consumption and dispersal by the spur-thighed tortoise Testudo graeca. Oikos, 51(3), 267. http://doi.org/10.2307/3565307

da Costa, G. 2012. Padrões alimentares durante um período de seca e investigação de endozoocoria por Podocnemis expansa (Testudines: Podocnemididae) na Reserva Biológica do Rio Trombetas, PA, Brasil. Instituto Nacional de Pesquisas Da Amazonia, Manaus.

Davis, S.D. 1996. Reproduction and diet of Kinosternon odoratum inhabiting a cold water reservoir in southwest Missouri, Unpubl. M.S. Thesis. Southest Missouri State University, Springfield

de Lima, A. C., Magnusson, W. E., \& da Costa, V. L. 1997. Diet of the turtle Phrynops rufipes in Central Amazonia. Copeia, $1997(1), 216$. http://doi.org/10.2307/1447862

de Neira, L. E. F., and M. K. Johnson. 1985. Diets of giant tortoises and feral burros on Volcan Alcedo, Galapagos. The Journal of Wildlife Management, 165-169.

Deepak, V. 2011. Ecology and behaviour of travancore tortoise (Indotestudo travancorica) in Anamalai Hills, Western Ghats. Retrieved from http://etheses.saurashtrauniversity.edu/590/1/deepak_v_thesis_wildlife\%20science.pdf

Deepak, V., \& Vasudevan, K. 2012. Feeding ecology of the Travancore tortoise (Indotestudo travancorica) in the Anamalais, Western Ghats, India

Díaz-Paniagua, C., Keller, C., \& Andreu, A. C. 1995. Annual variation of activity and daily distances moved in adult spur-thighed tortoises, Testudo graeca, in southwestern Spain. Herpetologica, 51(2), 225-233. http://doi.org/10.2307/3892590?ref=searchgateway:5163e322701902f21d23da697ad3dba9

Dodd, C.K. 2001. North America Box Turtles: A Natural History. University of Oklahoma Press, Norman. 231 p.

Donaldson, B. M., \& Echternacht, A. C. 2009. Aquatic habitat use relative to home range and seasonal movement of eastern box turtles (Terrapene carolina carolina: Emydidae) in eastern Tennessee. Dx.Doi.org, 39(2), 278-284. http://doi.org/10.1670/00221511(2005)039[0278:AHURTH]2.0.CO;2 
Doroff, A. M., \& Keith, L. B. 1990. Demography and ecology of an ornate box turtle (Terrapene ornata) population in south-central Wisconsin. Copeia, (2), 387-399.

Duda, J. J., Krzysik, A. J., \& Freilich, J. E. 1999. Effects of drought on desert tortoise movement and activity. Journal of Wildlife Management, 63(4), 1181-1192.

Edge, C. B., Steinberg, B. D., Brooks, R. J., \& Litzgus, J. D. 2015. Habitat selection by Blanding's turtles (Emydoidea blandingii) in a relatively pristine landscape. Ecoscience, 17(1), 90-99. http://doi.org/10.2980/17-1-3317

Elbers, J. P., and D. Moll. 2011. Ingestion by a freshwater turtle alters germination of bottomland hardwood seeds. Wetlands 31:757-761.

Elbers, J.P. 2010. Effect of Ingestion by Alligator Snapping Turtles (Macrochelys temminckii) on seeds of riparian vegetation. Unpubl. M.S. Thesis, Missouri State University, Springfield

Ellis-Soto, D., Blake, S., Soultan, A., Guezou, A., Cabrera, F., \& Lötters, S. 2017. Plant species dispersed by Galapagos tortoises surf the wave of habitat suitability under anthropogenic climate change. PLOS ONE, 12(7), e0181333. http://doi.org/10.1371/journal.pone.0181333

Elsey, R. M. 2006. Food Habits of Macrochelys temminckii (Alligator Snapping Turtle) from Arkansas and Louisiana. Southeastern Naturalist 5:443-452. Ernst, C. H., Altenburg, R. G. M., \& Babour, R. W. 1989. Turtles of the World. Washington D.C.: Smithsonian Institute Press.

Ernst, C.H. and J.E. Lovich. 2009. Turtles of the United States and Canada 2nd (Ed.. The Johns Hopkins University Press, Baltimore, 827 p.

Eubanks, J. O., Michener, W. K., \& Guyer, C. 2003. Patterns of movement and burrow use in a population of gopher tortoises (Gopherus polyphemus. Herpetologica, 59(3), 311-321.

Evenden, F. G. 1948. Distribution of the turtles of western Oregon. Herpetologica 4:201-204.

Fachín-Terán, A., \& Vogt, R. C. 2014. Alimentación de Podocnemis sextuberculata (Testudines: Podocnemididae) en la Reserva Mamirauá, Amazonas, Brasil. Revista Colombiana De Ciencia Animal - RECIA, 6(2), 285-298. http://doi.org/10.24188/recia.v6.n2.2014.431

Fachín-Terán, A., Vogt, R. C., \& Gomez, M. 1995. Food habits of an assemblage of five species of turtles in the Rio Guapore, Rondonia, Brazil. Journal of Herpetology, 29(4), 536. http://doi.org/10.2307/1564736

Falcón, W. 2018. Frugivory and seed dispersal by chelonians: From individuals to communities. PhD Thesis, University of Zurich.

Feuer, R.C. 1966. Variation in Snapping Turtles, Chelydra serpentina (linnaeus): A study in Quantitative Systematics. Ph.D. dissertation. Univ. Utah, Salt Lake City.

Figueroa, I. C. F., Fachín-Terán, A., \& Duque, S. R. 2012. Componentes alimenticios de Podocnemis unifilis y P. expansa (Testudines: Podocnemididae) en el resguardo Curare-Los ingleses, Amazonas, Colombia. Revista Colombiana De Ciencia Animal, 4(2), 441-453.

Ford, D. K., \& Moll, D. 2004. Sexual and Seasonal Variation in Foraging Patterns in the Stinkpot, Sternotherus odoratus, in Southwestern Missouri. Journal of Herpetology, 38(2), 296-301. http://doi.org/10.1670/172-03N

Forero-Medina, G., Cárdenas-Arevalo, G., \& Castaño-Mora, O. V. 2012. Abundance, Home Range, and Movement Patterns of the Endemic Species Dahl's Toad-Headed Turtle (Mesoclemmys dahli) in Cesar, Colombia. Dx.Doi.org, 10(2), 228-236. http://doi.org/10.2744/CCB-0929.1 
Franks, B. R., Avery, H. W., \& Spotila, J. R. 2011. Home range and movement of desert tortoises Gopherus agassizii in the Mojave Desert of California, USA. Endangered Species Research, 13(3), 191-201. http://doi.org/10.3354/esr00313

Franz, R., Hummel, J., Mueller, D. W. H., Bauert, M., Hatt, J.-M., \& Clauss, M. 2011. Herbivorous reptiles and body mass: Effects on food intake, digesta retention, digestibility and gut capacity, and a comparison with mammals. Comparative Biochemistry and Physiology, Part A, 158(1), 94-101. http://doi.org/10.1016/j.cbpa.2010.09.007

Freeman, A. 2010. Saving a living fossil: identification and mitigation of threats to the conservation status of the freshwater turtle, Elseya lavarackorum. Department of Environment, Water, Heritage, and the Arts. Canberra.

Freeman, A., Thomason, S., and Cann, J. 2014. Elseya lavarackorum (White and Archer 1994) - Gulf Snapping Turtle, Gulf Snapper, Riversleigh Snapping Turtle, Lavarack's Turtle. In: Rhodin, A.G.J., Pritchard, P.C.H., van Dijk, P.P., Saumure, R.A., Buhlmann, K.A., Iverson, J.B., and Mittermeier, R.A., (Eds.. Conservation Biology of Freshwater Turtles and Tortoises: A Compilation Project of the IUCN/SSC Tortoise and Freshwater Turtle Specialist Group. Chelonian REsearch Monographs 5(7):082.1-10, doi:10.3854/crm.5.082.lavarackorum.v1.2014,http://www.iucntfsg.org/cbftt/.

Galois, P., Leveille, M., Bouthillier, L., Daigle, C., \& Parren, S. 2002. Movement patterns, activity and home range of the eastern spiny softshell turtle (Apalone spinifera) in northern Lake Champlain, Quebec, Vermont. Journal of Herpetology, 36(3), 402-411.

Geffen, E., \& Mendelssohn, H. 1988. Home range use and seasonal movements of the Egyptian tortoise (Testudo kleinmanni) in the northwestern Negev, Israel. Herpetologica, 44(3), 354-359.

Georges, A., \& Kennett, R. 1989. Dry-season distribution and ecology of Carettochelys insculpta (Chelonia: Carettochelydidae) in Kakadu National Park, northern Australia. Australian Wildlife Research.

Georges, A., J. S. Doody, C. Eisemberg, E. Alacs, and M. Rose. 2008. Carettochelys insculpta Ramsay 1886-pig-nosed turtle, Fly River turtle. Chelonian Research Monographs 5:9.1-9.17.

Gibbs, J. P., Marquez, C., \& Sterling, E. J. 2008. The role of endangered species reintroduction in ecosystem restoration: Tortoise-cactus interactions on espanola island, Galapagos. Restoration Ecology, 16(1), 88-93. http://doi.org/10.1111/j.1526-100X.2007.00265.x

Goulding, M. 1980. The fishes and the forest: explorations in Amazonian natural history. Univ of California Press.

Gramentz, D. 2011. Lissemys punctata: The Indian Flap-shelled turtle. Edition Chimaira. Frankfurt am Main. 288 p.

Griffiths, C. J., D. M. Hansen, N. Zuël, C. G. Jones, and S. Harris. 2011. Resurrecting extinct interactions with extant substitutes. Current Biology 21:762765.

Griffiths, C., Z. Ahamud, N. Zuel, C. Jones and S. Harris. 2013. Return of the giant tortoises: Introducting surrogate tortoises to Round Island. The Tortoise 1(28):118-127.

Gundlach, J. 1880. Contribución a la herpetología Cubana. G. Montiel y Ca. Habana, 1-98. 
Guzman, A., and P. R. Stevenson. 2008. Seed dispersal, habitat selection and movement patterns in the Amazonian tortoise, Geochelone denticulata. Amphibia-Reptilia 29:463-472.

Hailey, A. 1989. How far do animals move? Routine movements in a tortoise. Canadian Journal of Zoology, 67(1), 208-215. http://doi.org/10.1139/z89028

Hailey, A. 1997. Digestive efficiency and gut morphology of omnivorous and herbivorous African tortoises. Canadian Journal of Zoology, 75(5), 787794. http://doi.org/10.1139/z97-100

Hailey, A. 1998. The specific dynamic action of the omnivorous tortoise Kinixys spekii in relation to diet, feeding pattern, and gut passage. Physiological Zoology, 71(1), 57-66.

Hailey, A., \& Coulson, I. M. 1996. Differential scaling of home-range area to daily movement distance in two African tortoises. Canadian Journal of Zoology, 74(1), 97-102.

Hamilton, J., \& Coe, M. 1982. Feeding, digestion and assimilation of a population of giant tortoises (Geochelone gigantea) (Schweigger) on Aldabra Atoll. Journal of Arid Environments, 5(2), 127-144.

Hansen, D. M., C. N. Kaiser, and C. B. Müller. 2008. Seed dispersal and establishment of endangered plants on oceanic Islands: The Janzen-Connell model, and the use of ecological analogues. PLoS ONE 3(5): e2111.doi:10.1371/journal.pone.0002111.

Hatt, J. M., Gisler, R., Mayes, R. W., Lechner-Doll, M., Clauss, M., Liesegang, A., \& Wanner, M. 2002. The use of dosed and herbage n-alkanes as markers for the determination of intake, digestibility, mean retention time and diet selection in Galapagos tortoises (Geochelone nigra. Herpetological Journal, 12, 45-54. http://doi.org/10.1017/S0021859600066910

Hnatiuk, S. H. 1978. Plant dispersal by the Aldabran giant tortoise, Geochelone gigantea (Schweigger. Oecologia 36:345-350.

Iftime, A., and O. Iftime. 2012. Long term observations on the alimentation of wild Eastern Greek Tortoises Testudo graeca ibera (Reptilia: Testudines: Testudinidae) in Dobrogea, Romania. Acta Herpetologica 7:105-110.

Innes, R. J., Babbitt, K. J., \& Kanter, J. J. 2008. Home Range and Movement of Blanding's Turtles (Emydoidea blandingii) in New Hampshire. dx.doi.org (Vol. 15, pp. 431-444. Northeastern Naturalist. http://doi.org/10.1656/1092-6194-15.3.431

Iverson, J.B. 1986. Notes on the natural history of the Oaxaca Mud turtle, Kinosternon oaxacae. J. Herp.20(1):119-123.

Iverson, J.B. 1988. Distribution and status of Creaser's mud turtle, Kinosternon creaseri. Herpetol. Jour. 1:285-291

Iverson, J.B. 1989. Natural history of the Alamos mud turtle, Kinosternon alamosae (Kinosternidae. Southwest. Nat. 34:134-142.

Jansen, K.P. 1993. Ecology of the tropical freshwater turtle Rhinoclemmys funerea in Caribbean Costa Rica. Unpubl. M.S. Thesis. Southwest Missouri State University, Springfield.

Jerozolimski, A., M. Ribeiro, and M. Martins. 2009. Are tortoises important seed dispersers in Amazonian forests? Oecologia 161:517-528.

Jones, R. L. 1996. Home range and seasonal movements of the turtle Graptemys flavimaculata. Journal of Herpetology, 30(3), 376-385. 
Jones, S.C., W.J. Jordan, S.J. Meiners, A.N. Miller, and A.S. Methven. 2007. Fungal spore dispersal by the Eastern Box Turtle (Terrapene carolina carolina. Am. Midl. Nat. 157:121-126.

Joshua, Q. I., M. D. Hofmeyr, and B. T. Henen. 2010. Seasonal and Site Variation in Angulate Tortoise Diet and Activity. Journal of Herpetology 44:124134.

Judd, F. W., \& Rose, F. L. 1983. Population-structure, density and movements of the Texas tortoise Gopherus berlandieri. The Southwestern Naturalist, 28(4), 387-398.

Kennett, R., \& Russell-Smith, J. 1993. Seed dispersal by freshwater turtles in northern Australia. Herpetology in Australia-A Diverse Discipline.

Kennett, R., and O. Tory. 1996. Diet of Two Freshwater Turtles, Chelodina rugosa and Elseya dentata (Testudines: Chelidae) from the Wet-Dry Tropics of Northern Australia. Copeia 1996:409-419.

Kimmons, J. B., and D. Moll. 2010. Seed Dispersal by Red-Eared Sliders (Trachemys scripta elegans) and Common Snapping Turtles (Chelydra serpentina. Chelonian Conservation and Biology 9:289-294.

Klimstra, W. D., and F. Newsome. 1960. Some Observations on the Food Coactions of the Common Box Turtle, Terrapene C. Carolina. Ecology 41:639647.

Kuchling, G., and Q. Bloxam. 1988. Field-data on the Madagascan flat tailed tortoise Pyxis (Acinixys) planicauda. Amphibia-Reptilia 9:175-180.

Lagarde, F., X. Bonnet, J. Corbin, B. Henen, K. Nagy, B. Mardonov, and G. Naulleau. 2003. Foraging behaviour and diet of an ectothermic herbivore: Testudo horsfieldi. Ecography 26:236-242.

Lagler, K. F. 1943. Food habits and economic relations of the turtles of Michigan with special reference to fish management. American Midland Naturalist:257-312.

Lambiris, A., J. C. Lambiris, and S.-A. Mather. 1989. Observations on Speke's hinged tortoise, Kinixys spekii Gray (Chelonii: Testudinidae. The Journal of the Herpetological Association of Africa 36:68-71.

Lautenschlager Rodrigues, L. 2016. Frugivoria e dispersão de sementes pelo jabuti-piranga Chelonoidis carbonaria. Universidade Estadual Paulista Júlio de Mesquita Filho, Rio Claro.

Lawson, D. P. 2006. Habitat use, home range, and activity patterns of hingeback tortoises, Kinixys erosa and K. homeana, in southwestern Cameroon. Chelonian Conservation and Biology, 5(1), 48-56.

Legler, J.M. 1960. Natural history of the ornate box turtle, Terrapene ornata ornata Agassiz. Univ. Kansas. Publ. Mus. Nat. History 11:527-669.

Legler, J.M. 1976. Feeding habits of some Australian Short-necked tortoises. Victorian Naturalist. 93:40-43.

Legler, J.M. and R.C. Vogt. 2013. The turtles of Mexico: Land and Freshwater Forms. Univ. California PRess, Berkely. 402 p.

Lickel, L. E. 2010. Intake, apparent digestibility, and digesta passage in leopard tortoises (Geochelone pardalis) fed a complete, extruded feed. California Polytechnic State University, San Luis Obispo.

Limpus, C. J., and D. J. Limpus. 2000. Mangroves in the diet of Chelonia mydas in Queensland, Australia. Marine Turtle Newsletter 89:13-15. 
Lingard. 2003. The role of local taboos in conservation and management of species: The radiated tortoise in southern Madagascar. Conservation and Society 1:223-246.

Litzgus, J. D., \& Mousseau, T. A. 2004. Home range and seasonal activity of southern spotted turtles (Clemmys guttata): Implications for managment. Copeia, (4), 804-817.

Liu, H., S. Platt, and C. Borg. 2004. Seed dispersal by the Florida box turtle (Terrapene carolina bauri) in pine rockland forests of the lower Florida Keys, United States. Oecologia 138:539-546.

Loehr, V. J. T. 2002. Diet of the Namaqualand speckled padloper, Homopus signatus signatus, in early spring. African Journal of Herpetology 51:47-55. Loehr, V. J. T. 2006. Natural Diet of the Namaqualand Speckled Padloper (Homopus signatus signatus. Chelonian Conservation and Biology 5:149-152.

Lopez-Leon, N.P., and R.C. Vogt. 2000. abstract) Digestive efficiency in three species of freshwater turtles: Dermatemys mawi, Rhinoclemmys areolata, and Trachemys scripta venusta. Annual Meeting American Society of Icthyologists and Herpetologists, Universidad Autonoma de Baja California Sur, 2000. La Paz, B.C.S.

Loveridge, A.H. and E.E. Williams. 1957. Revision of the African tortoises and turtles of the suborder Cryptodira. Bull. Mus. Comp. Zool. at Harvard College 115:163-557

Lue, K. Y., \& Chen, T. H. 1999. Activity, movement patterns, and home range of the yellow-margined box turtle (Cuora flavomarginata) in northern Taiwan. Dx.Doi.org, 33(4), 590-600.

Luiselli, L. 2003. Seasonal activity patterns and diet divergence of three sympatric Afrotropical tortoise species (genus Kinixys. Contributions to Zoology 72:211-220.

Macip-Rios, R., V. H. Sustaita-Rodriguez, G. Barrios-Quiroz, and G. Casas-Andreu. 2010. Alimentary Habits of the Mexican Mud Turtle (Kinosternon integrum) in Tonatico, Estado de México. Chelonian Conservation and Biology 9:90-97.

Magnusson, W. E., A. Cardoso de Lima, V. Lopes da Costa, and R.C. Vogt. 1997. Home Range of the turtle, Phrynops rufipes in an isolated reserve in central Amazonia, Brazil. Chelonian Conservation and Biology 2(4):494-499.

Mazzotti, S., Pisapia, A., \& Fasola, M. 2002. Activity and home range of Testudo hermanni in Northern Italy. Amphibia-Reptilia, 23(3), 305-312. http://doi.org/10.1163/15685380260449180

McMaster, M. K., \& Downs, C. T. 2009. Home range and daily movement of leopard tortoises (Stigmochelys pardalis) in the Nama-Karoo, South Africa. Journal of Herpetology, 43(4), 561-569. http://doi.org/10.1670/07-078.1

Millar, C. S., \& Blouin-Demers, G. 2011. Spatial Ecology and Seasonal Activity of Blanding's Turtles (Emydoidea blandingii) in Ontario, Canada. Dx.Doi.org, 45(3), 370-378. http://doi.org/10.1670/10-172.1

Milton, S. J. 1992. Plants Eaten and Dispersed by Adult Leopard Tortoises Geochelone-Pardalis (Reptilia, Chelonii) in the Southern Karoo. South African Journal of Zoology, 27(2), 45-49. 
Moldowan, P. D., Keevil, M. G., Mills, P. B., Brooks, R. J., \& Litzgus, J. D. 2016. Diet and feeding behaviour of Snapping Turtles (Chelydra serpentina) and Midland Painted Turtles (Chrysemys picta marginata) in Algonquin Provincial Park, Ontario. The Canadian Field-Naturalist, 129(4), $403-408$. http://doi.org/10.22621/cfn.v129i4.1764

Moll, D. 1976. Food and Feeding Strategies of the Ouachita Map Turtle (Graptemys pseudogeographica ouachitensis. American Midland Naturalist 96:478-482.

Moll, D. 1989. Food and feeding behavior of the turtle, Dermatemys mawei, in Belize. Journal of Herpetology:445-447.

Moll, D. 2008. Dietary characteristcs and seed germination influences of Desert Tortoises (Gopherus agassizii) in a very wet year (1998) in the northeastern Sonoran Desert. Sonoran Herpetologist 21(8):86-89.

Moll, D. and E. O. Moll. 2004. The ecology, exploitation and conservation of river turtles. Oxford University Press, New York. 393 p.

Moll, D., and K. P. Jansen. 1995. Evidence for a role in seed dispersal by two tropical herbivorous turtles. Biotropica 27:121-127.

Moll, E. O. 1980a. Natural history of the river Terrapin Batagur baska (Gray) in Malaysia (Testudines-Emydidae) Malaysian J. Sci. 6(A):23-62

Moll, E. O. 1980b. Tuntong Laut: The river turtle that goes to sea. Nature Malaysiana 5(2):17-21

Moll, E.O., and J.M. Legler. 1971. The life history of a neotropical slider turtle, Pseudemys scripta (Schoepff), in Panama. Bull. Los Angeles Co. Mus. Nat. Hist. 11:1-102.

Moolna, A. 2008. Preliminary observations indicate that giant tortoise ingestion improves seed germination for an endemic ebony species in Mauritius. African Journal of Ecology 46:217.

Morrow, J. L., Howard, J. H., Smith, S. A., \& Poppel, D. K. 2001. Home range and movements of the bog turtle (Clemmys muhlenbergii) in Maryland. Journal of Herpetology, 35(1), 68-73.

Moskovits, D. K., \& Kiester, A. R. 1987. Activity Levels and Ranging Behaviour of the Two Amazonian Tortoises, Geochelone carbonaria and Geochelone denticulata, in north-Western Brazil. Functional Ecology, 1(3), 203-214. http://doi.org/10.2307/2389422? ref=searchgateway:5163e322701902f21d23da697ad3dba9

Moskovits, D. K., and K. A. Bjorndal. 1990. Diet and food preferences of the tortoises Geochelone carbonaria and Geochelone denticulata in Northwestern Brazil. Herpetologica 46:207-218.

Murray, I. W., \& Wolf, B. O. 2013. Desert Tortoise (Gopherus agassizii) Dietary Specialization Decreases across a Precipitation Gradient. PLoS ONE, 8(6), e66505. http://doi.org/10.1371/journal.pone.0066505

Nieuwolt, P. M. 1996. Movement, activity, and microhabitat selection in the western box turtle, Terrapene ornata luteola, in New Mexico. Herpetologica, 52(4), 487-495.

O'Connor, M. P., Zimmerman, L. C., Ruby, D. E., Bulova, S. J., \& Spotila, J. R. 1994. Home range size and movements by desert tortoises, Gopherus agassizii, in the eastern Mojave Desert. Herpetological Monographs, 8, 60-71. 
Obbard, M. E., \& Brooks, R. J. 1981. A radio-telemetry and mark-recapture study of activity in the common snapping turtle, Chelydra serpentina. Copeia, (3), 630-637.

Padgett, D. J., J. J. Carboni, and D. J. Schepis. 2010. The Dietary Composition of Chrysemys picta picta (Eastern Painted Turtles) with Special Reference to the Seeds of Aquatic Macrophytes. Northeastern Naturalist 17:305-312.

Parmenter, R. R. 1981. Digestive turnover rates in freshwater turtles: The influence of temperature and body size. Comparative Biochemistry and Physiology Part a: Physiology, 70(2), 235-238. http://doi.org/10.1016/0300-9629(81)91451-1

Parmenter, R.R. 1980. Effects of food availability and water temperature on the feeding ecology of pond sliders (Chrysemys s. scripta. Copeia 1980 (3):503-514.

Parmenter, R.R. and H. W. Avery. 1990. The feeding ecology of the slider turtle. pp. 257-266. In: Gibbons, J.W., Life History and Ecology of the Slider Turtle, Smithsonian University Press. Wasington D.C.

Pemberton, J. W., and J. S. Gilchrist. 2009. Foraging Behavior and Diet Preferences of a Released Population of Giant Tortoises in the Seychelles. Chelonian Conservation and Biology 8:57-65.

Perez-Eman, J. L., and A. Paolillo. 1997. Diet of the Pelomedusid Turtle Peltocephalus dumerilianus in the Venezuelan Amazon. Journal of Herpetology 31:173-179.

Platt, K., Platt, S. G., \& Rainwater, T. R. 2014a. First record of the spiny turtle (Heosemys spinosa) in Myanmar. Chelonian Conservation and Biology, 13(2), 257-U165. http://doi.org/10.2744/CCB-1082.1

Platt, S. G., Berezin, A. R., Miller, D. J., \& Rainwater, T. R. 2016. A dietary study of the rough-footed mud turtle (Kinosternon hirtipes) in Texas, USA. Herpetological Conservation and Biology, 11(1), 142-149.

Platt, S. G., Hall, C., Liu, H., \& Borg, C. K. 2009. Wet-season food habits and intersexual dietary overlap of florida box turtles (Terrapene carolina bauri) on National Key Deer Wildlife Refuge, Florida. Southeastern Naturalist, 8(2), 335-346. http://doi.org/10.1656/058.008.0212

Platt, S. G., Myo, K. M., Ko, W. K., Maung, A., \& Rainwater, T. R. 2010. Field Observations and Conservation of Heosemys depressa in the Rakhine Yoma Elephant Range of Western Myanmar. Dx.Doi.org, 9(1), 114-119. http://doi.org/10.2744/CCB-0813.1

Platt, S. G., Platt, K., Khaing, L. L., Yu, T. T., Soe, M. M., Nwe, S. S., et al. 2014b. Heosemys depressa in the Southern Chin Hills of Myanmar: A Significant Range Extension and Traditional Ecological Knowledge. Dx.Doi.org, 13(2), 252-256. http://doi.org/10.2744/CCB-1077.1

Platt, S. G., S. T. Khaing, and W. K. Ko. 2001. A tortoise survey of Shwe Settaw Wildlife Sanctuary, Myanmar, with notes on the ecology of Geochelone platynota and Indotestudo elongata. Chelonian Conservation and Biology 4:172-177.

Plummer, M. V., and D. B. Farrar. 1981. Sexual Dietary Differences in a Population of Trionyx muticus. Journal of Herpetology 15:175-179.

Pritchard, P.C.H. 1989. The Alligator Snapping Turtle: Biology and Conservation. Milwaukee Public Museum 104 p.

Raney, E. C., \& Lachner, E. A. 1942. Summer Food of Chrysemys picta marginata, in Chautauqua Lake, New York. Copeia, 1942(2), 83-85. http://doi.org/10.2307/1439123?ref=search-gateway:933dc26a414881f039e24fab75fa251f 
Rasoma, R. V. J., A. P. Raselimanana, Y. R. Ratovonamana, and J. U. Ganzhorn. 2013. Habitat Use and Diet of Astrochelys radiata in the Subarid Zone of Southern Madagascar. Chelonian Conservation and Biology 12:56-69.

Renvoize, S. A. 1971. The origin and distribution of the flora of Aldabra. Phil. Trans. Roy. Soc. Lond. B. 260:227-236.

Rick, C. M., and R. I. Bowman. 1961. Galápagos tomatoes and tortoises. Evolution 15:407-417.

Roe, J. H., \& Georges, A. 2008. Terrestrial activity, movements and spatial ecology of an Australian freshwater turtle, Chelodina longicollis, in a temporally dynamic wetland system. Austral Ecology, 33(8), 1045-1056. http://doi.org/10.1111/j.1442-9993.2008.01877.x

Rose, F.L. and F. W. Judd. 1982. The biology and status of Berlandier's tortoise (Gopherus berlandieri), p. 57-70. In: R.B. Bury (Ed.), North American tortoises: Conservation and Ecology. U.S. Fish and Wildlife Service Wild. Res. Rept. 12

Ross, D. A., \& Anderson, R. K. 1990. Habitat use, movements, and nesting of Emydoidea blandingi in central Wisconsin. Journal of Herpetology, 24(1), 6-12.

Rouag, R., C. Ferrah, L. Luiselli, G. Tiar, S. Benyacoub, N. Ziane, and E. H. El Mouden. 2008. Food choice of an Algerian population of the spur-thighed tortoise, Testudo graeca. African Journal of Herpetology 57:103-113.

Rowe, J. W. 2003. Activity and movements of midland painted turtles (Chrysemys picta marginata) living in a small marsh system on Beaver Island, Michigan. Dx.Doi.org, 37(2), 342-353.

Rowe, J. W., \& Moll, E. O. 1991. A radiotelemetric study of activity and movements of the Blandings turtle (Emydoidea blandingi) in northeastern Illinois. Journal of Herpetology, 25(2), 178-185.

Rust, R., and R. Roth. 1981. Seed production and seedling establishment in the mayapple, Podophyllum peltatum L. American Midland Naturalist:5160.

Ryan, T. J., Peterman, W. E., Stephens, J. D., \& Sterrett, S. C. 2014. Movement and habitat use of the snapping turtle in an urban landscape. Urban Ecosystems, 17(2), 613-623. http://doi.org/10.1007/s11252-013-0324-1

Sadeghayobi, E., S. Blake, M. Wikelski, J. Gibbs, R. Mackie, and F. Cabrera. 2011. Digesta retention time in the Galápagos tortoise (Chelonoidis nigra. Comparative Biochemistry and Physiology - Part A: Molecular \&amp; Integrative Physiology 160:493-497.

Sammantano, D.V. 1994. Spatial, dietary, and temporal niche parameters of two species of box turtle, (Terrapene) in Microsympatry. Unpubl. M.S. Thesis Southwest Missouri State University, Springfield.

Santos-Júnior, L. B. 2009, August 19. Dieta de Podocnemis erythrocephala (Testudines: Podocnemididae) no Parque Nacional do Jaú, Amazonas, Brasil. Instituto Nacional de Pesquisas da Amazônia, Amazonas.

Seminoff, J. A., Resendiz, A., \& Nichols, W. J. 2002. Home range of green turtles Chelonia mydas at a coastal foraging area in the Gulf of California, Mexico. Marine Ecology Progress Series, 242, 253-265.

Setlalekgomo, M. R., \& Sesinyi, K. 2014. Seed dispersal by serrated tortoises (Psammobates oculiferus) and the effect of their gut passage on seed germination. Scientific Journal of Animal Science, 3(10), 252-257. http://doi.org/10.14196/sjas.v3i10.1720 
Sloan, K.N., K.A. Buhlmann, and J.E. Lovich. 1996. Stomach contents of commercially harvested adult Alligator Snapping Turtles Macroclemmys temminckii. Chelonian Conservation and Biology 2:96-99.

Smith, L. M., \& Cherry, R. P. 2016. Movement, Seasonal Activity, and Home Range of an Isolated Population of Glyptemys muhlenbergii, Bog Turtle, in the Southern Appalachians. Southeastern Naturalist, 15(2), 207-219. http://doi.org/10.1656/058.015.0202

Snider, J. R. 1993. Foraging ecology and sheltersite characteristics of Sonoran Desert tortoises. Pages 82-84 in Proceedings of the Desert Tortoise Council Symposium.

Spencer, R.-J., M. B. Thompson, and I. D. Hume. 1998. The diet and digestive energetics of an Australian short-necked turtle, Emydura macquarii. Comparative Biochemistry and Physiology - Part A: Molecular \&amp; Integrative Physiology 121:341-349.

Stickel, L. F. 1989. Home range behavior among box turtles (Terrapene c. carolina) of a bottomland forest in Maryland. Journal of Herpetology, 23(1), 40-44.

Stone, M. D., and D. Moll. 2009. Abundance and Diversity of Seeds in Digestive Tracts of Terrapene carolina and T. ornata in Southwestern Missouri. The Southwestern Naturalist 54:346-350.

Stone, M. D., and Moll, Don. 2006. Diet-Dependent Differences in Digestive Efficiency in Two Sympatric Species of Box Turtles, Terrapene carolina and Terrapene ornata. Journal of Herpetology 40:364-371.

Strang, C. A. 1983. Spatial and temporal activity patterns in two terrestrial turtles. Journal of Herpetology, 17(1), $43-47$.

Strong, J. N., and J. M. V. Fragoso. 2006. Seed dispersal by Geochelone carbonaria and Geochelone denticulata in Northwestern Brazil. Biotropica 38:683-686.

Sung, Y. H., Hau, B. C. H., \& Karraker, N. E. 2016. Diet of the endangered big-headed turtle Platysternon megacephalum. PeerJ, 2016(12), 10. http://doi.org/10.7717/peerj.2784

Surface, H.A. 1908. First report on the economic features of the turtles of Pennsylviania. Zool. Bull. Div. Zoo. Pennsylvania Dept. Agric. 6:105-196.

Teran, A. F., R. C. Vogt, and M. d. F. S. Gomez. 1995. Food Habits of an Assemblage of Five Species of Turtles in the Rio Guapore, Rondonia, Brazil. Journal of Herpetology 29:536-547.

Tol, S.J., Jarvis, J.C., York, P.H., Grech, A., Congdon, B.C. and Coles, R.G., 2017. Long distance biotic dispersal of tropical seagrass seeds by marine megaherbivores. Scientific Reports, 7(1), p.4458.

Tracy, R. C., Zimmerman, L. C., Tracy, C., Bradley, K. D., \& Castle, K. 2006. Rates of food passage in the digestive tract of young desert tortoises: effects of body size and diet quality. Chelonian Conservation and Biology, 5(2), 269-273. http://doi.org/10.2744/10718443(2006)5[269:ROFPIT]2.0.CO;2

Trembath, D. F. 2005. The Comparative Ecology of Krefft's River Turtle'Emydura Krefftii in Tropical North Queensland. University of Canberra, Applied Ecology Research Unit. 
Tulipani, D. C., and R. N. Lipcius. 2014. Evidence of Eelgrass (Zostera marina) Seed Dispersal by Northern Diamondback Terrapin (Malaclemys terrapin terrapin) in Lower Chesapeake Bay. PLoS ONE 9:e103346.

Turner, F. B., P. A. Medica, and C. L. Lyons. 1984. Reproduction and survival of the desert tortoise (Scaptochelys agassizii) in Ivanpah Valley, California. Copeia:811-820.

Turner, L.K. 1995. Reproduction and diet of Pseudemys concinna inhabiting a cold water reservoir in southwest Missouri. Unpubl. M.S. thesis. Southwest Missouri State University, Springfield

van Dijk, P. P. 1998): The Natural History of the Elongated Tortoise, Indotestudo elongata (Blyth, 1853) in a Hill Forest Mosaic in Western Thailand, With Notes on Sympatric Tur- tle Species. Ph.D Dissertation. National University of Ireland, Galway.

Varela, R. O., and E. H. Bucher. 2002. Seed dispersal by Chelonoidis chilensis in the Chaco dry Woodland of Argentina. Journal of Herpetology 36:137140.

Vijaya, J. 1983. The Travancore tortoise Geochelone travancorica. Hamadrayad 8:11-13.

Vijaya, J. H. 1982. Rediscovery of the forest cane turtle (Heosemys silvatica) of Kerala. Hamadryad, 7(3): 2-3.

Villa R. 2013. Tortuga De La Sierra Madre: My encounter with a cryptic and elusive turtle. The Tortoise 1(2): 150-157.

Vogt, R. C., and S. G. Guzman. 1988. Food Partitioning in a Neotropical Freshwater Turtle Community. Copeia 1988:37-47.

Vogt, R.C., Polisar, J.R., Moll, D., and Gonzalez-Porter, G. 2011. Dermatemys mawii Gray 1847 - Central American River Turtle, Tortuga Blanca, Hickatee. In: Rhodin, A.G.J., Prichard, P.C.H., van Dijk, P.P., Saumure, R.A., Buhlmann, K.A., Iverson, J.B., and Mittermeier, R.A. Eds.. Conservation Biology of Freshwater Turtles and Tortoises: A compilation Project of the IUCN/SSC Tortoise and Freshwater Turtle Specialists Group. Chelonian Research Monographs No. 5, pp. 058.1-058.12, doi:10.3854/crm.5.058.mawii.v1.201,http://www.iucn-tfsg.org/cbftt/.

Vogt, R.C., S.G. Platt, and T.R. Rainwater. 2009. Rhinoclemmys areolata (Dumeril and Bibron 1851) - furrowed wood turtle, black-bellied turtle, mojina. In: A.G.J. Rhodin, P.C.H. Pritchard, P.P. van Dijk, R.A. Saumure, K. A. Buhlmann, J.B. Iverson, and R.A. Mittermeier (Eds.. Chelonian REsearch Monographs No. 5, pp. 022.1-022.7, doi:10.3854/crm.5.022. areolata.v1.2009, http://www.iucn-tftsg.org/cbftt/. Conservation Biology of Freshwater Turtles and Tortoises: A Compilation PRoject of IUCN/SSC Tortoisoe and Freshwater Turtle Specialist Group.

Waller, T., P. Micucchi, and E. Richard. 1989. Preliminary results of the research on biology, ecology and Conservation of the Chelonoidis chilensis (sensu lato)(Gray, 1870) tortoise in Argentina. KZ T., WWF-TRAFFIC Sudamerica and CITES Secretariat publ. 43pp.

Wang, E., C. I. Donatti, V. L. Ferreira, J. Raizer, and J. Himmelstein. 2011. Food habits and notes on the biology of Chelonoidis carbonaria (Spix 1824) (Testudinidae, Chelonia) in the southern Pantanal, Brazil. South American Journal of Herpetology 6:11-19.

Wilson, M., and I. R. Lawler. 2008. Diet and digestive performance of an urban population of the omnivorous freshwater turtle (Emydura krefftii) from Ross River, Queensland. Australian Journal of Zoology 56:151-157.

Winokur, R.M. 1968. The morphology and relationships of the Soft-shelled turtles of the Cuatro Cienegas Basin, Coahuila, Mexico. MSc Thesis, Arizona State University, Tempe. 
bioRxiv preprint doi: https://doi org/10.1101/379933; this version posted July 30,2018. The copyright holder for this preprint (which was not certified by peer review) is the author/funder, who has granted bioRxiv a license to display the preprint in perpetuity. It is made available under aCC-BY-NC-ND 4.0 International license.

Falcón et al. Seed dispersal by chelonians

S2: Chelonian species that engage in frugivory and seed dispersal, and the species of plants that they consumed and/or disperse.

\begin{tabular}{|c|c|c|}
\hline Reference & Chelonian species & Plant species \\
\hline Amorocho and Reina 2008 & Chelonia mydas & Rhizophora mangle \\
\hline Andriantsaralaza et. al. 2013 & Aldabrachelys gigantea & Adansonia fony \\
\hline Armstrong and Booth 2005 & Elseya albagula & Costanospermum australe \\
\hline Arthur et. al. 2008 & Chelonia mydas & Unidentified 'mangrove' \\
\hline Auffenberg and Weaver 1969 & Gopherus berlandieri & Aristida sp. \\
\hline Auffenberg and Weaver 1969 & Gopherus berlandieri & Aster sp. \\
\hline Auffenberg and Weaver 1969 & Gopherus berlandieri & Buchloe sp. \\
\hline Auffenberg and Weaver 1969 & Gopherus berlandieri & Celtis pallida \\
\hline Auffenberg and Weaver 1969 & Gopherus berlandieri & Cenchrus sp. \\
\hline Auffenberg and Weaver 1969 & Gopherus berlandieri & Chloris sp. \\
\hline Auffenberg and Weaver 1969 & Gopherus berlandieri & Citharexylum sp. \\
\hline Auffenberg and Weaver 1969 & Gopherus berlandieri & Plantago sp. \\
\hline Auffenberg and Weaver 1969 & Gopherus berlandieri & Viola sp. \\
\hline Auffenberg and Weaver 1969 & Gopherus berlandieri & Xanthophyllum sp. \\
\hline Auffenberg and Weaver 1969 & Gopherus berlandieri & Cylindropuntia leptocaulis \\
\hline Auffenberg and Weaver 1969 & Gopherus berlandieri & Opuntia engelmannii \\
\hline Ayres et. al. 2010 & Emys orbicularis & Nymphaea alba \\
\hline Balensiefer and Vogt 2006 & Podocnemis unifilis & Eichhornia sp. \\
\hline Balensiefer and Vogt 2006 & Podocnemis unifilis & Pistia sp. \\
\hline Balensiefer and Vogt 2006 & Podocnemis unifilis & Pseudobombax munguba \\
\hline Balensiefer and Vogt 2006 & Podocnemis unifilis & Salvinia sp. \\
\hline Balensiefer and Vogt 2006 & Podocnemis unifilis & Unidentified Sapindaceae \\
\hline Balensiefer and Vogt 2006 & Podocnemis unifilis & Unidentified Poaceae \\
\hline Balensiefer and Vogt 2006 & Podocnemis unifilis & Unidentified Myrtaceae \\
\hline Balensiefer and Vogt 2006 & Podocnemis unifilis & Unidentified Melastomataceae \\
\hline Balensiefer and Vogt 2006 & Podocnemis unifilis & Unidentified Fabaceae \\
\hline Balensiefer and Vogt 2006 & Podocnemis unifilis & Unidentified Fabaceae \\
\hline Balensiefer and Vogt 2006 & Podocnemis unifilis & Unidentified Bombacaceae \\
\hline Birkhead et. al. 2005 & Gopherus polyphemus & Acalypha gracilens \\
\hline Birkhead et. al. 2005 & Gopherus polyphemus & Ambrosia sp. \\
\hline Birkhead et. al. 2005 & Gopherus polyphemus & Asclepias sp. \\
\hline Birkhead et. al. 2005 & Gopherus polyphemus & Commelina erecta \\
\hline Birkhead et. al. 2005 & Gopherus polyphemus & Crataegus sp. \\
\hline Birkhead et. al. 2005 & Gopherus polyphemus & Digitaria sp. \\
\hline Birkhead et. al. 2005 & Gopherus polyphemus & Dyschoriste oblongifolia \\
\hline Birkhead et. al. 2005 & Gopherus polyphemus & Gaillardia aestivalis \\
\hline Birkhead et. al. 2005 & Gopherus polyphemus & Hypericum sp. \\
\hline Birkhead et. al. 2005 & Gopherus polyphemus & Licania michauxii \\
\hline Birkhead et. al. 2005 & Gopherus polyphemus & Mollugo verticillata \\
\hline Birkhead et. al. 2005 & Gopherus polyphemus & Oenothera sp. \\
\hline Birkhead et. al. 2005 & Gopherus polyphemus & Opuntia humifusa \\
\hline Birkhead et. al. 2005 & Gopherus polyphemus & Oxalis sp. \\
\hline Birkhead et. al. 2005 & Gopherus polyphemus & Panicum sp. \\
\hline Birkhead et. al. 2005 & Gopherus polyphemus & Paspalum sp. \\
\hline Birkhead et. al. 2005 & Gopherus polyphemus & Physalis heterophylla \\
\hline
\end{tabular}


bioRxiv preprint doi: https://doi org/10.1101/379933; this version posted July 30,2018 . The copyright holder for this preprint (which was not certified by peer review) is the author/funder, who has granted bioRxiv a license to display the preprint in perpetuity. It is made available under aCC-BY-NC-ND 4.0 International license.

Falcón et al. Seed dispersal by chelonians

Birkhead et. al. 2005

Birkhead et. al. 2005

Birkhead et. al. 2005

Birkhead et. al. 2005

Birkhead et. al. 2005

Birkhead et. al. 2005

Birkhead et. al. 2005

Birkhead et. al. 2005

Birkhead et. al. 2005

Birkhead et. al. 2005

Birkhead et. al. 2005

Birkhead et. al. 2005

Birkhead et. al. 2005

Birkhead et. al. 2005

Birkhead et. al. 2005

Birkhead et. al. 2005

Birkhead et. al. 2005

Birkhead et. al. 2005

Birkhead et. al. 2005

Birkhead et. al. 2005

Birkhead et. al. 2005

Birkhead et. al. 2005

Blake et. al. 2012

Blake et. al. 2012

Blake et. al. 2012

Blake et. al. 2012

Blake et. al. 2012

Blake et. al. 2012

Blake et. al. 2012

Blake et. al. 2012

Blake et. al. 2012

Blake et. al. 2012

Blake et. al. 2012

Blake et. al. 2012

Blake et. al. 2012

Blake et. al. 2012

Blake et. al. 2012

Blake et. al. 2012

Blake et. al. 2012

Blake et. al. 2012

Blake et. al. 2012

Blake et. al. 2012

Blake et. al. 2012

Blake et. al. 2012

Blake et. al. 2012

Blake et. al. 2012

Blake et. al. 2012

Blake et. al. 2012

Blake et. al. 2012
Gopherus polyphemus

Gopherus polyphemus

Gopherus polyphemus

Gopherus polyphemus

Gopherus polyphemus

Gopherus polyphemus

Gopherus polyphemus

Gopherus polyphemus

Gopherus polyphemus

Gopherus polyphemus

Gopherus polyphemus

Gopherus polyphemus

Gopherus polyphemus

Gopherus polyphemus

Gopherus polyphemus

Gopherus polyphemus

Gopherus polyphemus

Gopherus polyphemus

Gopherus polyphemus

Gopherus polyphemus

Gopherus polyphemus

Gopherus polyphemus

Chelonoidis nigra

Chelonoidis nigra

Chelonoidis nigra

Chelonoidis nigra

Chelonoidis nigra

Chelonoidis nigra

Chelonoidis nigra

Chelonoidis nigra

Chelonoidis nigra

Chelonoidis nigra

Chelonoidis nigra

Chelonoidis nigra

Chelonoidis nigra

Chelonoidis nigra

Chelonoidis nigra

Chelonoidis nigra

Chelonoidis nigra

Chelonoidis nigra

Chelonoidis nigra

Chelonoidis nigra

Chelonoidis nigra

Chelonoidis nigra

Chelonoidis nigra

Chelonoidis nigra

Chelonoidis nigra

Chelonoidis nigra

Chelonoidis nigra

\section{Plantago sp.}

Polygala sp.

Polygonum sp.

Prunus angustifolia

Prunus sp.

Rhynchospora sp.

Rubus sp.

Rumex sp.

Sclerodactylon macrostachyum

Stellaria media

Tradescantia ohiensis

Tragia urens

Veronica hederifolia

Zornia bracteata

Ipomoea sp.

Stylosanthes biflora

Asimina angustifolia

Passiflora edulis

Piriqueta cistoides

Mimosa quadrivalvis

Diodia sp.

Richardia sp.

Anthephora hermaphrodita

Blainvillea dichotoma

Brickellia diffusa

Cenchrus platyacanthus

Commelina diffusa

Cordia lutea

Crotalaria pumila

Cynodon dactylon

Cyperus ligularis

Desmodium incanum

Digitaria setigera

Eleocharis maculosa

Eleusine indica

Eriochloa pacifica

Hippomane mancinella

Ipomoea triloba

Kyllinga brevifolia

Opuntia echios

Panicum dichotomiflorum

Panicum maximum

Paspalum conjugatum

Passiflora edulis

Physalis pubescens

Pisonia floribunda

Polygonum opelousanum

Portulaca oleracea

Psidium galapageium 
bioRxiv preprint doi: https://doi. org/10.1101/379933; this version posted July 30, 2018. The copyright holder for this preprint (which was not certified by peer review) is the author/funder, who has granted bioRxiv a license to display the preprint in perpetuity. It is made available under aCC-BY-NC-ND 4.0 International license.

Falcón et al. Seed dispersal by chelonians

\begin{tabular}{|c|c|c|}
\hline Blake et. al. 2012 & Chelonoidis nigra & Psidium guajava \\
\hline Blake et. al. 2012 & Chelonoidis nigra & Rubus niveus \\
\hline Blake et. al. 2012 & Chelonoidis nigra & Scleria distans \\
\hline Blake et. al. 2012 & Chelonoidis nigra & Scleria hirtella \\
\hline Blake et. al. 2012 & Chelonoidis nigra & Sida rhombifolia \\
\hline Blake et. al. 2012 & Chelonoidis nigra & Sida spinosa \\
\hline Blake et. al. 2012 & Chelonoidis nigra & Sida spinosa \\
\hline Blake et. al. 2012 & Chelonoidis nigra & Solanum americanum \\
\hline Blake et. al. 2012 & Chelonoidis nigra & Stachytarpheta cayennensis \\
\hline Blake et. al. 2012 & Chelonoidis nigra & Synedrella nodiflora \\
\hline Blake et. al. 2012 & Chelonoidis nigra & Tradescantia fluminensis \\
\hline Blake et. al. 2012 & Chelonoidis nigra & Zanthoxylum fagara \\
\hline Blake et. al. 2012 & Chelonoidis nigra & Acacia rorudia \\
\hline Blake et. al. 2012 & Chelonoidis nigra & Bidens sp. \\
\hline Blake et. al. 2012 & Chelonoidis nigra & Galactia striata \\
\hline Blake et. al. 2012 & Chelonoidis nigra & Clerodendrum villosum \\
\hline Blake et. al. 2012 & Chelonoidis nigra & Brachiaria multiculma \\
\hline Blake et. al. 2012 & Chelonoidis nigra & Brachiaria mutica \\
\hline Blake et. al. 2012 & Chelonoidis nigra & Hippomane mancinella \\
\hline Blake et. al. 2012 & Chelonoidis nigra & Opuntia echios \\
\hline Blake et. al. 2012 & Chelonoidis nigra & Passiflora edulis \\
\hline Blake et. al. 2012 & Chelonoidis nigra & Psidium galapageium \\
\hline Blake et. al. 2012 & Chelonoidis nigra & Psidium guajava \\
\hline Blake et. al. 2015 & Chelonoidis nigra & Anthephora hermaphrodita \\
\hline Blake et. al. 2015 & Chelonoidis nigra & Axonopus micay \\
\hline Blake et. al. 2015 & Chelonoidis nigra & Blainvillea dichotoma \\
\hline Blake et. al. 2015 & Chelonoidis nigra & Brickellia diffusa \\
\hline Blake et. al. 2015 & Chelonoidis nigra & Cenchrus platyacanthus \\
\hline Blake et. al. 2015 & Chelonoidis nigra & Cordia lutea \\
\hline Blake et. al. 2015 & Chelonoidis nigra & Cyperus ligularis \\
\hline Blake et. al. 2015 & Chelonoidis nigra & Desmodium glabrum \\
\hline Blake et. al. 2015 & Chelonoidis nigra & Desmodium incanum \\
\hline Blake et. al. 2015 & Chelonoidis nigra & Digitaria setigera \\
\hline Blake et. al. 2015 & Chelonoidis nigra & Eleocharis maculosa \\
\hline Blake et. al. 2015 & Chelonoidis nigra & Eleusine indica \\
\hline Blake et. al. 2015 & Chelonoidis nigra & Eragrostis cilianensis \\
\hline Blake et. al. 2015 & Chelonoidis nigra & Eriochloa pacifica \\
\hline Blake et. al. 2015 & Chelonoidis nigra & Hippomane mancinella \\
\hline Blake et. al. 2015 & Chelonoidis nigra & Ipomoea triloba \\
\hline Blake et. al. 2015 & Chelonoidis nigra & Opuntia echios \\
\hline Blake et. al. 2015 & Chelonoidis nigra & Panicum dichotomiflorum \\
\hline Blake et. al. 2015 & Chelonoidis nigra & Panicum maximum \\
\hline Blake et. al. 2015 & Chelonoidis nigra & Paspalum conjugatum \\
\hline Blake et. al. 2015 & Chelonoidis nigra & Passiflora edulis \\
\hline Blake et. al. 2015 & Chelonoidis nigra & Pennisetum purpureum \\
\hline Blake et. al. 2015 & Chelonoidis nigra & Physalis pubescens \\
\hline Blake et. al. 2015 & Chelonoidis nigra & Pisonia floribunda \\
\hline Blake et. al. 2015 & Chelonoidis nigra & Polygonum opelousanum \\
\hline Blake et. al. 2015 & Chelonoidis nigra & Portulaca oleracea \\
\hline
\end{tabular}


bioRxiv preprint doi: https://doi. org/10.1101/379933; this version posted July 30,2018 . The copyright holder for this preprint (which was not certified by peer review) is the author/funder, who has granted bioRxiv a license to display the preprint in perpetuity. It is made available under aCC-BY-NC-ND 4.0 International license.

Falcón et al. Seed dispersal by chelonians

\begin{tabular}{|c|c|c|}
\hline Blake et. al. 2015 & Chelonoidis nigra & Psidium galapageium \\
\hline Blake et. al. 2015 & Chelonoidis nigra & Psidium guajava \\
\hline Blake et. al. 2015 & Chelonoidis nigra & Rubus niveus \\
\hline Blake et. al. 2015 & Chelonoidis nigra & Scleria distans \\
\hline Blake et. al. 2015 & Chelonoidis nigra & Scleria hirtella \\
\hline Blake et. al. 2015 & Chelonoidis nigra & Sida rhombifolia \\
\hline Blake et. al. 2015 & Chelonoidis nigra & Sida salviifolia \\
\hline Blake et. al. 2015 & Chelonoidis nigra & Silene dichotoma \\
\hline Blake et. al. 2015 & Chelonoidis nigra & Solanum ochraceo-ferrugineum \\
\hline Blake et. al. 2015 & Chelonoidis nigra & Stachytarpheta cayennensis \\
\hline Blake et. al. 2015 & Chelonoidis nigra & Synedrella nodiflora \\
\hline Blake et. al. 2015 & Chelonoidis nigra & Tradescantia fluminensis \\
\hline Blake et. al. 2015 & Chelonoidis nigra & Zanthoxylum fagara \\
\hline Blake et. al. 2015 & Chelonoidis nigra & Acacia rorudia \\
\hline Blake et. al. 2015 & Chelonoidis nigra & Bidens sp. \\
\hline Blake et. al. 2015 & Chelonoidis nigra & Clerodendrum villosum \\
\hline Bonin et. al. 2006 & Batagur baska & Sorocea sp. \\
\hline Bonin et. al. 2006 & Batagur borneonensis & Unidentified 'mangrove' \\
\hline Bonin et. al. 2006 & Carettochelys insculpta & Pandanus aquaticus \\
\hline Bonin et. al. 2006 & Carettochelys insculpta & Syzygium forte \\
\hline Bonin et. al. 2006 & Chelonoidis denticulata & Jacaratia spinosa \\
\hline Bonin et. al. 2006 & Kinosternon baurii & Unidentified Arecaceae \\
\hline Bonin et. al. 2006 & Kinosternon scorpioides & Unidentified Arecaceae \\
\hline Bonin et. al. 2006 & Macrochelys temminckii & Quercus sp. \\
\hline Bonin et. al. 2006 & Mesoclemmys nasuta & Philodendron sp. \\
\hline Bonin et. al. 2006 & Trionyx triunguis & Phoenix sp. \\
\hline Bonin et. al. 2006 & Emydura subglobosa & Pandanus sp. \\
\hline Braun and Brooks 1987 & Terrapene carolina & Podophyllum peltatum \\
\hline Braun and Brooks 1987 & Terrapene carolina & Podophyllum peltatum \\
\hline Braun and Brooks 1987 & Terrapene carolina & Rubus sp. \\
\hline Braun and Brooks 1987 & Terrapene carolina & Vaccinium sp. \\
\hline Braun and Brooks 1987 & Terrapene carolina & Viburnum sp. \\
\hline Braun and Brooks 1987 & Terrapene carolina & Vitis rotundifolia \\
\hline Braun and Brooks 1987 & Terrapene carolina & Arisaema triphyllum \\
\hline Braun and Brooks 1987 & Terrapene carolina & Duchesnea indica \\
\hline Braun and Brooks 1987 & Terrapene carolina & Fragaria virginiana \\
\hline Braun and Brooks 1987 & Terrapene carolina & Gaylussacia baccata \\
\hline Braun and Brooks 1987 & Terrapene carolina & Morus alba \\
\hline Braun and Brooks 1987 & Terrapene carolina & Phytolacca americana \\
\hline Braun and Brooks 1987 & Terrapene carolina & Podophyllum peltatum \\
\hline Braun and Brooks 1987 & Terrapene carolina & Podophyllum peltatum \\
\hline Braun and Brooks 1987 & Terrapene carolina & Prunus sp. \\
\hline Braun and Brooks 1987 & Terrapene carolina & Rosa multiflora \\
\hline Braun and Brooks 1987 & Terrapene carolina & Rubus phoenicolasius \\
\hline Braun and Brooks 1987 & Terrapene carolina & Rubus sp. \\
\hline Braun and Brooks 1987 & Terrapene carolina & Vaccinium vacillans \\
\hline Braun and Brooks 1987 & Terrapene carolina & Vitis aestivalis \\
\hline Braun and Brooks 1987 & Terrapene carolina & Vitis rotundifolia \\
\hline Braun and Brooks 1987 & Terrapene carolina & Vitis vulpina \\
\hline
\end{tabular}


bioRxiv preprint doi: https://doi org/10.1101/379933; this version posted July 30,2018 . The copyright holder for this preprint (which was not certified by peer review) is the author/funder, who has granted bioRxiv a license to display the preprint in perpetuity. It is made available under aCC-BY-NC-ND 4.0 International license.

Falcón et al. Seed dispersal by chelonians

\begin{tabular}{|c|c|c|}
\hline Braun and Brooks 1987 & Terrapene carolina & Passiflora edulis \\
\hline Burgin and Renshaw 2008 & Chelodina longicollis & Eleocharis acuta \\
\hline Burgin and Renshaw 2008 & Chelodina longicollis & Eleocharis sp. \\
\hline Burgin and Renshaw 2008 & Chelodina longicollis & Gahnia sp. \\
\hline Burgin and Renshaw 2008 & Chelodina longicollis & Juncus sp. \\
\hline Burgin and Renshaw 2008 & Chelodina longicollis & Paspalum dilatatum \\
\hline Burgin and Renshaw 2008 & Chelodina longicollis & Polygonum sp. \\
\hline Burgin and Renshaw 2008 & Chelodina longicollis & Potamogeton sp. \\
\hline Burgin and Renshaw 2008 & Chelodina longicollis & Sagittaria graminea \\
\hline Burgin and Renshaw 2008 & Chelodina longicollis & Scirpus sp. \\
\hline Calviño-Cancela et. al. 2007 & Emys orbicularis & Nymphaea alba \\
\hline Caputo and Vogt 2008 & Phrynops rufipes & Bactris sp. \\
\hline Caputo and Vogt 2008 & Phrynops rufipes & Iriartella setigera \\
\hline Caputo and Vogt 2008 & Phrynops rufipes & Mauritia flexuosa \\
\hline Caputo and Vogt 2008 & Phrynops rufipes & Mauritia flexuosa \\
\hline Caputo and Vogt 2008 & Phrynops rufipes & Oenocarpus bataua \\
\hline Caputo and Vogt 2008 & Phrynops rufipes & Socratea exorrhiza \\
\hline Caputo and Vogt 2008 & Phrynops rufipes & Socratea exorrhiza \\
\hline Caputo and Vogt 2008 & Phrynops rufipes & Unidentified Sapotaceae \\
\hline Caputo and Vogt 2008 & Phrynops rufipes & Unidentified Rubiaceae \\
\hline Caputo and Vogt 2008 & Phrynops rufipes & Unidentified Malvaceae \\
\hline Caputo and Vogt 2008 & Phrynops rufipes & Unidentified Fabaceae \\
\hline Caputo and Vogt 2008 & Phrynops rufipes & Unidentified Clusiaceae \\
\hline Caputo and Vogt 2008 & Phrynops rufipes & Unidentified Arecaceae \\
\hline Caputo and Vogt 2008 & Phrynops rufipes & Euterpe precatoria \\
\hline Carlson et. al. 2003 & Gopherus polyphemus & Digitaria $s p$ \\
\hline Carlson et. al. 2003 & Gopherus polyphemus & Diodella teres \\
\hline Carlson et. al. 2003 & Gopherus polyphemus & Euphorbia maculata \\
\hline Carlson et. al. 2003 & Gopherus polyphemus & Licania michauxii \\
\hline Carlson et. al. 2003 & Gopherus polyphemus & Paspalum notatum \\
\hline Carlson et. al. 2003 & Gopherus polyphemus & Paspalum setaceum \\
\hline Carlson et. al. 2003 & Gopherus polyphemus & Quercus geminata \\
\hline Carlson et. al. 2003 & Gopherus polyphemus & Paspalum notatum \\
\hline Carlson et. al. 2003 & Gopherus polyphemus & Paspalum setaceum \\
\hline Cobo and Reu 1988 & Testudo graeca & Agrostis sp. \\
\hline Cobo and Reu 1988 & Testudo graeca & Anthoxanthum ovatum \\
\hline Cobo and Reu 1988 & Testudo graeca & Briza maxima \\
\hline Cobo and Reu 1988 & Testudo graeca & Briza minor \\
\hline Cobo and Reu 1988 & Testudo graeca & Carduus meonanthus \\
\hline Cobo and Reu 1988 & Testudo graeca & Carduus sp. \\
\hline Cobo and Reu 1988 & Testudo graeca & Cerastium glomeratum \\
\hline Cobo and Reu 1988 & Testudo graeca & Corynephorus sp. \\
\hline Cobo and Reu 1988 & Testudo graeca & Cynodon dactylon \\
\hline Cobo and Reu 1988 & Testudo graeca & Erodium sp. \\
\hline Cobo and Reu 1988 & Testudo graeca & Halimium halimifolium \\
\hline Cobo and Reu 1988 & Testudo graeca & Hypochaeris glabra \\
\hline Cobo and Reu 1988 & Testudo graeca & Isolepis sp. \\
\hline Cobo and Reu 1988 & Testudo graeca & Juncus sp. \\
\hline Cobo and Reu 1988 & Testudo graeca & Leontodon taraxacoides \\
\hline
\end{tabular}


bioRxiv preprint doi: https://doi org/10.1101/379933; this version posted July 30,2018 . The copyright holder for this preprint (which was not certified by peer review) is the author/funder, who has granted bioRxiv a license to display the preprint in perpetuity. It is made available under aCC-BY-NC-ND 4.0 International license.

Falcón et al. Seed dispersal by chelonians

\begin{tabular}{|c|c|c|}
\hline Cobo and Reu 1988 & Testudo graeca & Malcolmia lacera \\
\hline Cobo and Reu 1988 & Testudo graeca & Moenchia erecta \\
\hline Cobo and Reu 1988 & Testudo graeca & Ononis sp. \\
\hline Cobo and Reu 1988 & Testudo graeca & Panicum repens \\
\hline Cobo and Reu 1988 & Testudo graeca & Paspalum sp. \\
\hline Cobo and Reu 1988 & Testudo graeca & Polypogon maritimus \\
\hline Cobo and Reu 1988 & Testudo graeca & Ranunculus sardous \\
\hline Cobo and Reu 1988 & Testudo graeca & Ranunculus sp. \\
\hline Cobo and Reu 1988 & Testudo graeca & Reseda media \\
\hline Cobo and Reu 1988 & Testudo graeca & Rubus ulmifolius \\
\hline Cobo and Reu 1988 & Testudo graeca & Rumex bucephalophorus \\
\hline Cobo and Reu 1988 & Testudo graeca & Simaba sp. \\
\hline Cobo and Reu 1988 & Testudo graeca & Spergula arvensis \\
\hline Cobo and Reu 1988 & Testudo graeca & Sporobolus sp. \\
\hline Cobo and Reu 1988 & Testudo graeca & Vulpia sp. \\
\hline Cobo and Reu 1988 & Testudo graeca & Lotus subbiflorus \\
\hline Cobo and Reu 1988 & Testudo graeca & Ornithophus sativus \\
\hline Cobo and Reu 1988 & Testudo graeca & Astragalus pelecinus \\
\hline Cobo and Reu 1988 & Testudo graeca & Bromus rigidus \\
\hline Cobo and Reu 1988 & Testudo graeca & Briza maxima \\
\hline Cobo and Reu 1988 & testudo graeca & Hypochaeris glabra \\
\hline Cobo and Reu 1988 & Testudo graeca & Rumex bucephalophorus \\
\hline Cobo and Reu 1988 & Testudo graeca & Spergula arvensis \\
\hline Cobo and Reu 1988 & Testudo graeca & Anagallis arvensis \\
\hline da Costa 2012 & Podocnemis expansa & Pouteria elegans \\
\hline da Costa 2012 & Podocnemis expansa & Psidium sp. \\
\hline da Costa 2012 & Podocnemis expansa & Oryza sp. \\
\hline da Costa 2012 & Podocnemis expansa & Duroia sp. \\
\hline da Costa 2012 & Podocnemis expansa & Unidentified \\
\hline da Costa 2012 & Podocnemis expansa & Unidentified \\
\hline da Costa 2012 & Podocnemis expansa & Unidentified \\
\hline Deepak 2011 & Indotestudo travancorica & Artocarpus sp. \\
\hline Deepak 2011 & Indotestudo travancorica & Dillenia pentagyna \\
\hline Deepak 2011 & Indotestudo travancorica & Dillenia pentagyna \\
\hline Deepak 2011 & Indotestudo travancorica & Ficus virens \\
\hline Deepak 2011 & Indotestudo travancorica & Gomphandra sp. \\
\hline Deepak 2011 & Indotestudo travancorica & Grewia tiliifolia \\
\hline Deepak 2011 & Indotestudo travancorica & Lantana camara \\
\hline de Lima et. al. 1997 & Phrynops rufipes & Euterpe precatoria \\
\hline de Lima et. al. 1997 & Phrynops rufipes & Iriartella sp. \\
\hline de Lima et. al. 1997 & Phrynops rufipes & Oenocarpus bacaba \\
\hline de Lima et. al. 1997 & Phrynops rufipes & "Munbaca" sp. \\
\hline de Lima et. al. 1997 & Phrynops rufipes & "Pupunharana" sp. \\
\hline de Lima et. al. 1997 & Phrynops rufipes & Socratea exorrhiza \\
\hline de Lima et. al. 1997 & Phrynops rufipes & Oenocarpus bataua \\
\hline de Lima et. al. 1997 & Phrynops rufipes & Unidentified Humiriaceae \\
\hline de Lima et. al. 1997 & Phrynops rufipes & Unidentified Fabaceae \\
\hline de Lima et. al. 1997 & Phrynops rufipes & Unidentified Euphorbiaceae \\
\hline de Lima et. al. 1997 & Phrynops rufipes & Unidentified [Annonaceae \\
\hline
\end{tabular}


bioRxiv preprint doi: https://doi org/10.1101/379933; this version posted July 30,2018 . The copyright holder for this preprint (which was not certified by peer review) is the author/funder, who has granted bioRxiv a license to display the preprint in perpetuity. It is made available under aCC-BY-NC-ND 4.0 International license.

Falcón et al. Seed dispersal by chelonians

\begin{tabular}{|c|c|c|}
\hline del Vecchio et. al. 2011 & Testudo hermanni & Carduus pycnocephalus \\
\hline del Vecchio et. al. 2011 & Testudo hermanni & Hedera helix \\
\hline del Vecchio et. al. 2011 & Testudo hermanni & Rubus ulmifolius \\
\hline del Vecchio et. al. 2011 & Testudo hermanni & Ruscus aculeatus \\
\hline del Vecchio et. al. 2011 & Testudo hermanni & Unidentified Fabaceae \\
\hline de Neira and Johnson 1985 & Chelonoidis nigra & Psidium galapageium \\
\hline Elbers and Moll 2011 & Macrochelys temminckii & Diospyros virginiana \\
\hline Elbers and Moll 2011 & Macrochelys temminckii & Nyssa aquatica \\
\hline Elbers and Moll 2011 & Macrochelys temminckii & Quercus phellos \\
\hline Ellis-Soto et. al. 2017 & Chelonoidis donfaustoi & Passiflora edulis \\
\hline Ellis-Soto et. al. 2017 & Chelonoidis donfaustoi & Psidium guajava \\
\hline Ellis-Soto et. al. 2017 & Chelonoidis porteri & Passiflora edulis \\
\hline Ellis-Soto et. al. 2017 & Chelonoidis porteri & Psidium guajava \\
\hline Elsey 2006 & Macrochelys temminckii & Quercus sp. \\
\hline Evenden 1948 & Actinemys marmorata & Nuphar polysepala \\
\hline Fachín-Terán 1995 et. al. & Mesoclemmys raniceps & Unidentified Fabaceae \\
\hline Fachín-Terán 1995 et. al. & Mesoclemmys raniceps & Unidentified Myrtaceae \\
\hline Fachín-Terán 1995 et. al. & Mesoclemmys raniceps & Unidentified Sapotaceae \\
\hline Fachín-Terán 1995 et. al. & Podocnemis unifilis & Diospyros sp. \\
\hline Fachín-Terán 1995 et. al. & Podocnemis unifilis & Margaritaria sp. \\
\hline Fachín-Terán 1995 et. al. & Podocnemis unifilis & Maripa sp. \\
\hline Fachín-Terán 1995 et. al. & Podocnemis unifilis & Pouteria sp. \\
\hline Fachín-Terán 1995 et. al. & Podocnemis unifilis & Unidentified Fabaceae \\
\hline Falcón 2018 & Aldabrachelys gigantea & Allophylus aldabricus \\
\hline Falcón 2018 & Aldabrachelys gigantea & Apodytes dimidiata \\
\hline Falcón 2018 & Aldabrachelys gigantea & Azima tetracantha \\
\hline Falcón 2018 & Aldabrachelys gigantea & Capparis cartilaginea \\
\hline Falcón 2018 & Aldabrachelys gigantea & Volkameria glabra \\
\hline Falcón 2018 & Aldabrachelys gigantea & Cordia subcordata \\
\hline Falcón 2018 & Aldabrachelys gigantea & Ehretia cymosa \\
\hline Falcón 2018 & Aldabrachelys gigantea & Ficus sundaica \\
\hline Falcón 2018 & Aldabrachelys gigantea & Ficus lutea \\
\hline Falcón 2018 & Aldabrachelys gigantea & Ficus reflexa \\
\hline Falcón 2018 & Aldabrachelys gigantea & Flacourtia ratmonchii \\
\hline Falcón 2018 & Aldabrachelys gigantea & Guettarda speciosa \\
\hline Falcón 2018 & Aldabrachelys gigantea & Aloe aldabrensis \\
\hline Falcón 2018 & Aldabrachelys gigantea & Cassine aethiopica \\
\hline Falcón 2018 & Aldabrachelys gigantea & Ochna ciliata \\
\hline Falcón 2018 & Aldabrachelys gigantea & Pandanus tectorius \\
\hline Falcón 2018 & Aldabrachelys gigantea & Scaevola taccada \\
\hline Falcón 2018 & Aldabrachelys gigantea & Solanum aldabrensis \\
\hline Falcón 2018 & Aldabrachelys gigantea & Terminalia boivinii \\
\hline Falcón 2018 & Aldabrachelys gigantea & Thespesia populnea \\
\hline Falcón 2018 & Aldabrachelys gigantea & Thespesia populneides \\
\hline Falcón 2018 & Aldabrachelys gigantea & Colubrina asiatica \\
\hline Falcón 2018 & Aldabrachelys gigantea & Pemphis acidula \\
\hline Falcón 2018 & Aldabrachelys gigantea & Casuarina equisetifolia \\
\hline Falcón 2018 & Aldabrachelys gigantea & Tournefortia argentata \\
\hline Falcón 2018 & Aldabrachelys gigantea & Abrus prectorius \\
\hline
\end{tabular}


bioRxiv preprint doi: https://doi.org/10.1101/379933; this version posted July 30, 2018. The copyright holder for this preprint (which was not certified by peer review) is the author/funder, who has granted bioRxiv a license to display the preprint in perpetuity. It is made available under aCC-BY-NC-ND 4.0 International license.

Falcón et al. Seed dispersal by chelonians

\begin{tabular}{|c|c|c|}
\hline Falcón 2018 & Aldabrachelys gigantea & Acalypha claoxyoides \\
\hline Figueroa et. al. 2012 & Podocnemis expansa & Erythrina sp. \\
\hline Figueroa et. al. 2012 & Podocnemis expansa & Ficus sp. \\
\hline Figueroa et. al. 2012 & Podocnemis expansa & Macrolobium acaciifolium \\
\hline Ford and Moll 2004 & Sternotherus odoratus & Ludwigia peploides \\
\hline Freeman 2010 & Elseya lavarackorum & Ficus racemosa \\
\hline Freeman 2010 & Elseya lavarackorum & Livistona rigida \\
\hline Freeman 2010 & Elseya lavarackorum & Nauclea orientalis \\
\hline Freeman 2010 & Elseya lavarackorum & Pandanus aquaticus \\
\hline Freeman 2010 & Elseya lavarackorum & Passiflora foetida \\
\hline Georges and Kennet 1989 & Carettochelys insculpta & Ficus racemosa \\
\hline Georges and Kennet 1989 & Carettochelys insculpta & Pandanus aquaticus \\
\hline Georges and Kennet 1989 & Carettochelys insculpta & Syzygium forte \\
\hline Georges et. al. 2008 & Carettochelys insculpta & Artocarpus altilis \\
\hline Georges et. al. 2008 & Carettochelys insculpta & Canarium indicum \\
\hline Georges et. al. 2008 & Carettochelys insculpta & Ficus racemosa \\
\hline Georges et. al. 2008 & Carettochelys insculpta & Nypa sp. \\
\hline Georges et. al. 2008 & Carettochelys insculpta & Pandanus aquaticus \\
\hline Georges et. al. 2008 & Carettochelys insculpta & Saccharum robustum \\
\hline Georges et. al. 2008 & Carettochelys insculpta & Syzygium forte \\
\hline Georges et. al. 2008 & Carettochelys insculpta & Xylocarpus sp. \\
\hline Gibbs et. al. 2008 & Chelonoidis nigra & Opuntia megasperma \\
\hline Goulding 1980 & Podocnemis expansa & Hevea spruceana \\
\hline Goulding 1980 & Podocnemis expansa & Macrolobium acaciifolium \\
\hline Griffiths et. al. 2011 & Aldabrachelys gigantea & Diospyros egrettarum \\
\hline Gundlach 1880 & Trachemys decussata & Annona glabra \\
\hline Gundlach 1880 & Trachemys decussata & Spondias mombin \\
\hline Guzmán and Stevenson 2008 & Chelonoidis denticulata & Annona sp. \\
\hline Guzmán and Stevenson 2008 & Chelonoidis denticulata & Astrocaryum murumuru \\
\hline Guzmán and Stevenson 2008 & Chelonoidis denticulata & Casearia macrocarpa \\
\hline Guzmán and Stevenson 2008 & Chelonoidis denticulata & Cayaponia ophthalmica \\
\hline Guzmán and Stevenson 2008 & Chelonoidis denticulata & Cecropia membranacea \\
\hline Guzmán and Stevenson 2008 & Chelonoidis denticulata & Clarisia racemosa \\
\hline Guzmán and Stevenson 2008 & Chelonoidis denticulata & Combretum sp. \\
\hline Guzmán and Stevenson 2008 & Chelonoidis denticulata & Coussapoa sp. \\
\hline Guzmán and Stevenson 2008 & Chelonoidis denticulata & Duguetia sp. \\
\hline Guzmán and Stevenson 2008 & Chelonoidis denticulata & Ficus sp. \\
\hline Guzmán and Stevenson 2008 & Chelonoidis denticulata & Ficus insipida \\
\hline Guzmán and Stevenson 2008 & Chelonoidis denticulata & Ficus maxima \\
\hline Guzmán and Stevenson 2008 & Chelonoidis denticulata & Ficus sp. \\
\hline Guzmán and Stevenson 2008 & Chelonoidis denticulata & Genipa americana \\
\hline Guzmán and Stevenson 2008 & Chelonoidis denticulata & Geophila repens \\
\hline Guzmán and Stevenson 2008 & Chelonoidis denticulata & Guatteria sp. \\
\hline Guzmán and Stevenson 2008 & Chelonoidis denticulata & Helicostylis tomentosa \\
\hline Guzmán and Stevenson 2008 & Chelonoidis denticulata & Inga sp. \\
\hline Guzmán and Stevenson 2008 & Chelonoidis denticulata & Iriartea deltoidea \\
\hline Guzmán and Stevenson 2008 & Chelonoidis denticulata & Jacaratia digitata \\
\hline Guzmán and Stevenson 2008 & Chelonoidis denticulata & Lecointea amazonica \\
\hline Guzmán and Stevenson 2008 & Chelonoidis denticulata & Loreya strigosa \\
\hline
\end{tabular}


bioRxiv preprint doi: https://doi org/10.1101/379933; this version posted July 30, 2018. The copyright holder for this preprint (which was not certified by peer review) is the author/funder, who has granted bioRxiv a license to display the preprint in perpetuity. It is made available under aCC-BY-NC-ND 4.0 International license.

Falcón et al. Seed dispersal by chelonians

\begin{tabular}{|c|c|c|}
\hline Guzmán and Stevenson 2008 & Chelonoidis denticulata & Miconia sp. \\
\hline Guzmán and Stevenson 2008 & Chelonoidis denticulata & Pourouma cecropiifolia \\
\hline Guzmán and Stevenson 2008 & Chelonoidis denticulata & Pourouma minor \\
\hline Guzmán and Stevenson 2008 & Chelonoidis denticulata & Pourouma sp. \\
\hline Guzmán and Stevenson 2008 & Chelonoidis denticulata & Pouteria sp. \\
\hline Guzmán and Stevenson 2008 & Chelonoidis denticulata & Pseudolmedia laevis \\
\hline Guzmán and Stevenson 2008 & Chelonoidis denticulata & Quiina peruviana \\
\hline Guzmán and Stevenson 2008 & Chelonoidis denticulata & Rollinia sp. \\
\hline Guzmán and Stevenson 2008 & Chelonoidis denticulata & Salacia gigantea \\
\hline Guzmán and Stevenson 2008 & Chelonoidis denticulata & Salacia sp. \\
\hline Guzmán and Stevenson 2008 & Chelonoidis denticulata & Sorocea sp. \\
\hline Guzmán and Stevenson 2008 & Chelonoidis denticulata & Spondias mombin \\
\hline Guzmán and Stevenson 2008 & Chelonoidis denticulata & Strychnos sp. \\
\hline Guzmán and Stevenson 2008 & Chelonoidis denticulata & Tetragastris sp. \\
\hline Guzmán and Stevenson 2008 & Chelonoidis denticulata & Virola surinamensis \\
\hline Guzmán and Stevenson 2008 & Chelonoidis denticulata & Mendoncia bivalvis \\
\hline Guzmán and Stevenson 2008 & Chelonoidis denticulata & Unidentified Poaceae 1 \\
\hline Guzmán and Stevenson 2008 & Chelonoidis denticulata & Unidentified Poaceae 2 \\
\hline Guzmán and Stevenson 2008 & Chelonoidis denticulata & Brosimum lactescens \\
\hline Guzmán and Stevenson 2008 & Chelonoidis denticulata & Cecropia sciadophylla \\
\hline Guzmán and Stevenson 2008 & Chelonoidis denticulata & Ficus sp1. \\
\hline Guzmán and Stevenson 2008 & Chelonoidis denticulata & Ficus sp 2. \\
\hline Hansen et. al. 2008 & Aldabrachelys gigantea & Rauvolfia micrantha \\
\hline Hnatiuk 1978 & Aldabrachelys gigantea & Syzygium mamillatum \\
\hline Hnatiuk 1978 & Aldabrachelys gigantea & Bulbostylis basalis \\
\hline Hnatiuk 1978 & Aldabrachelys gigantea & Colubrina asiatica \\
\hline Hnatiuk 1978 & Aldabrachelys gigantea & Cyperus ligularis \\
\hline Hnatiuk 1978 & Aldabrachelys gigantea & Dactyloctenium ctenoides \\
\hline Hnatiuk 1978 & Aldabrachelys gigantea & Eragrostis decumbens \\
\hline Hnatiuk 1978 & Aldabrachelys gigantea & Eragrostis subaequiglumis \\
\hline Hnatiuk 1978 & Aldabrachelys gigantea & Euphorbia sp. \\
\hline Hnatiuk 1978 & Aldabrachelys gigantea & Fimbristylis ferruginea \\
\hline Hnatiuk 1978 & Aldabrachelys gigantea & Guettarda speciosa \\
\hline Hnatiuk 1978 & Aldabrachelys gigantea & Lepturus repens \\
\hline Hnatiuk 1978 & Aldabrachelys gigantea & Ochna ciliata \\
\hline Hnatiuk 1978 & Aldabrachelys gigantea & Phyllanthus maderaspatensis \\
\hline Hnatiuk 1978 & Aldabrachelys gigantea & Portulaca mauritiensis \\
\hline Hnatiuk 1978 & Aldabrachelys gigantea & Scaevola taccada \\
\hline Hnatiuk 1978 & Aldabrachelys gigantea & Serenoa repens \\
\hline Hnatiuk 1978 & Aldabrachelys gigantea & Solanum americanum \\
\hline Hnatiuk 1978 & Aldabrachelys gigantea & Sporobolus testudinum \\
\hline Hnatiuk 1978 & Aldabrachelys gigantea & Sporobolus virginicus \\
\hline Hnatiuk 1978 & Aldabrachelys gigantea & Stachytarpheta jamaicensis \\
\hline Hnatiuk 1978 & Aldabrachelys gigantea & Terminalia boivinii \\
\hline Hnatiuk 1978 & Aldabrachelys gigantea & Thespesia populnea \\
\hline Hnatiuk 1978 & Aldabrachelys gigantea & Dactyloctenium pilosum \\
\hline Hnatiuk 1978 & Aldabrachelys gigantea & Hedyotis prolifera \\
\hline Hnatiuk 1978 & Aldabrachelys gigantea & Pycreus pumilus \\
\hline Hnatiuk 1978 & Aldabrachelys gigantea & Ficus sundaica \\
\hline
\end{tabular}


bioRxiv preprint doi: https://doi.org/10.1101/379933; this version posted July 30, 2018. The copyright holder for this preprint (which was not certified by peer review) is the author/funder, who has granted bioRxiv a license to display the preprint in perpetuity. It is made available under aCC-BY-NC-ND 4.0 International license.

Falcón et al. Seed dispersal by chelonians

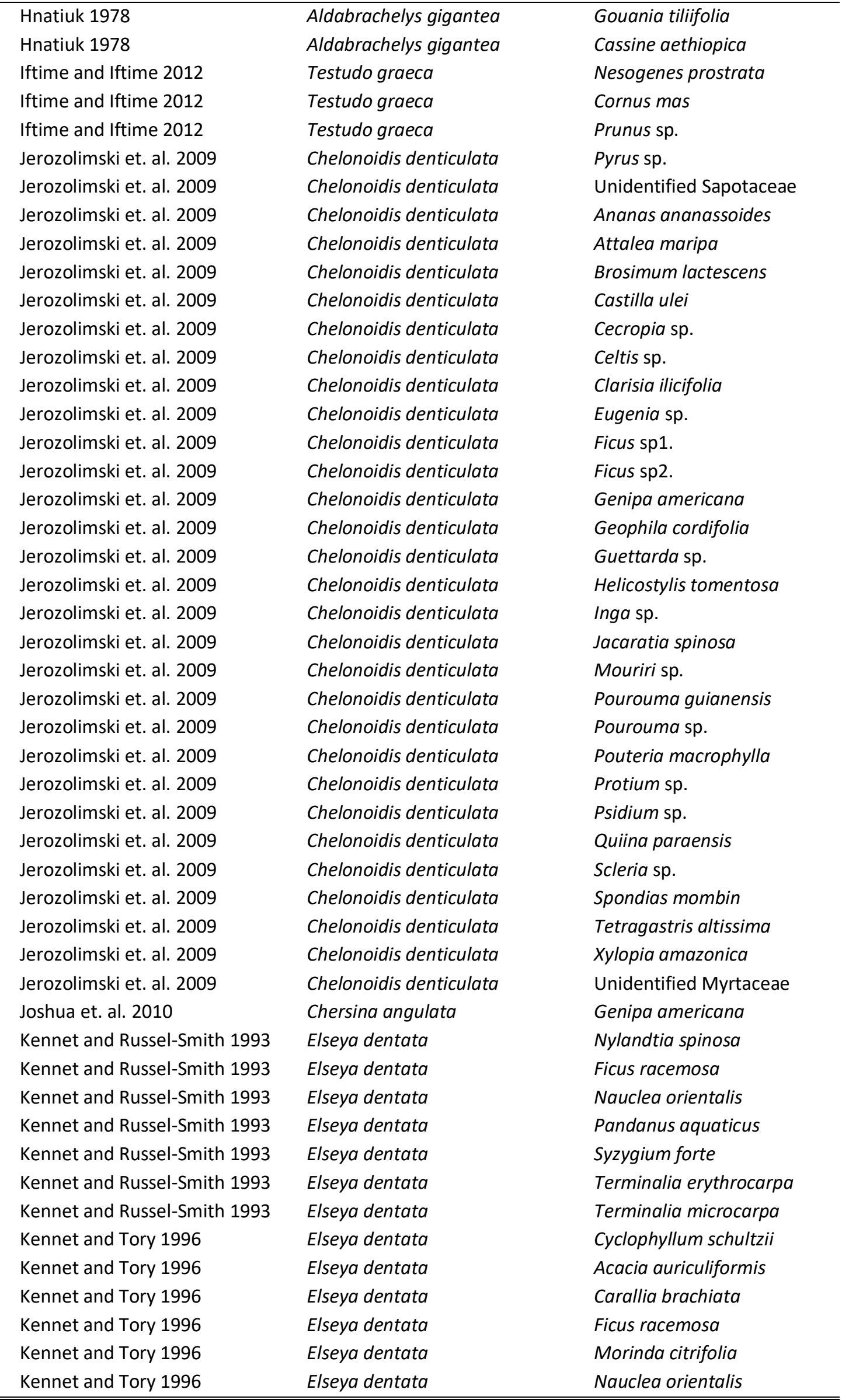


bioRxiv preprint doi: https://doi org/10.1101/379933; this version posted July 30,2018. The copyright holder for this preprint (which was not certified by peer review) is the author/funder, who has granted bioRxiv a license to display the preprint in perpetuity. It is made available under aCC-BY-NC-ND 4.0 International license.

Falcón et al. Seed dispersal by chelonians

\begin{tabular}{|c|c|c|}
\hline Kennet and Tory 1996 & Elseya dentata & Pandanus aquaticus \\
\hline Kennet and Tory 1996 & Elseya dentata & Terminalia erythrocarpa \\
\hline Kimmons and Moll 2010 & Chelydra serpentina & Ambrosia sp. \\
\hline Kimmons and Moll 2010 & Chelydra serpentina & Echinochloa crus-galli \\
\hline Kimmons and Moll 2010 & Chelydra serpentina & Elymus repens \\
\hline Kimmons and Moll 2010 & Chelydra serpentina & Morus sp. \\
\hline Kimmons and Moll 2010 & Chelydra serpentina & Panicum sp. \\
\hline Kimmons and Moll 2010 & Chelydra serpentina & Polygonum sp. \\
\hline Kimmons and Moll 2010 & Chelydra serpentina & Ranunculus sceleratus \\
\hline Kimmons and Moll 2010 & Trachemys scripta & Rumex crispus \\
\hline Kimmons and Moll 2010 & Trachemys scripta & Echinochloa crus-galli \\
\hline Kimmons and Moll 2010 & Trachemys scripta & Morus sp. \\
\hline Kimmons and Moll 2010 & Trachemys scripta & Polygonum sp. \\
\hline Kimmons and Moll 2010 & Trachemys scripta & Ranunculus sceleratus \\
\hline Kimmons and Moll 2010 & Trachemys scripta & Rumex crispus \\
\hline Kimmons and Moll 2010 & Trachemys scripta & Rumex obtusifolius \\
\hline Kimmons and Moll 2010 & Trachemys scripta & Setaria verticillata \\
\hline Kimmons and Moll 2010 & Chelydra serpentina & Silene nocturna \\
\hline Kimmons and Moll 2010 & Chelydra serpentina & Echinochloa crus-galli \\
\hline Kimmons and Moll 2010 & Chelydra serpentina & Morus sp. \\
\hline Kimmons and Moll 2010 & Trachemys scripta & Rumex crispus \\
\hline Kimmons and Moll 2010 & Trachemys scripta & Echinochloa crus-galli \\
\hline Kimmons and Moll 2010 & Trachemys scripta & Morus sp. \\
\hline Klimstra and Newsome 1960 & Terrapene carolina & Rumex crispus \\
\hline Klimstra and Newsome 1960 & Terrapene carolina & Hordeum sp. \\
\hline Klimstra and Newsome 1960 & Terrapene carolina & Bromus sp. \\
\hline Klimstra and Newsome 1960 & Terrapene carolina & Paspalum sp. \\
\hline Klimstra and Newsome 1960 & Terrapene carolina & Rubus sp. \\
\hline Klimstra and Newsome 1960 & Terrapene carolina & Prunus sp. \\
\hline Klimstra and Newsome 1960 & Terrapene carolina & Fragaria sp. \\
\hline Klimstra and Newsome 1960 & Terrapene carolina & Diospyros virginiana \\
\hline Klimstra and Newsome 1960 & Terrapene carolina & Morus rubra \\
\hline Klimstra and Newsome 1960 & Terrapene carolina & Polygonum sp. \\
\hline Klimstra and Newsome 1960 & Terrapene carolina & Unidentified Caryophillaceae \\
\hline Klimstra and Newsome 1960 & Terrapene carolina & Galium sp. \\
\hline Klimstra and Newsome 1960 & Terrapene carolina & Ambrosia sp. \\
\hline Klimstra and Newsome 1960 & Terrapene carolina & Unidentified Chenopodiaceae \\
\hline Klimstra and Newsome 1960 & Terrapene carolina & Unidentified Cyperaceae \\
\hline Klimstra and Newsome 1960 & Terrapene carolina & Vitis sp. \\
\hline Kuchling and Bloxam 1988 & Pyxis planicauda & Breonia perrieri \\
\hline Kuchling and Bloxam 1988 & Pyxis planicauda & Broussonetia greveana \\
\hline Lagler 1943 & Chelydra serpentina & Nymphaea odorata \\
\hline Lagler 1943 & Chelydra serpentina & Bidens sp. \\
\hline Lagler 1943 & Chrysemys picta & Nymphaea odorata \\
\hline Lagler 1943 & Chrysemys picta & Triticum sp. \\
\hline Lagler 1943 & Chrysemys picta & Zea mays \\
\hline Lagler 1943 & Emys blandingii & Cornus amomum \\
\hline Lagler 1943 & Emys blandingii & Bidens sp. \\
\hline Lagler 1943 & Graptemys geographica & Potamogeton sp. \\
\hline
\end{tabular}


bioRxiv preprint doi: https://doi.org/10.1101/379933; this version posted July 30, 2018. The copyright holder for this preprint (which was not certified by peer review) is the author/funder, who has granted bioRxiv a license to display the preprint in perpetuity. It is made available under aCC-BY-NC-ND 4.0 International license.

Falcón et al. Seed dispersal by chelonians

\begin{tabular}{|c|c|c|}
\hline Lagler 1943 & Sternotherus odoratus & Cornus amomum \\
\hline Lagler 1943 & Sternotherus odoratus & Nuphar sp. \\
\hline Lagler 1943 & Sternotherus odoratus & Nymphaea odorata \\
\hline Lagler 1943 & Sternotherus odoratus & Bidens sp. \\
\hline Lambiris et. al. 1989 & Kinixys spekii & Uapaca kirkiana \\
\hline Lautenschlager-Rodrigues 2016 & Chelonoidis carbonaria & Abuta selloana \\
\hline Lautenschlager-Rodrigues 2016 & Chelonoidis carbonaria & Acrocomia aculeata \\
\hline Lautenschlager-Rodrigues 2016 & Chelonoidis carbonaria & Archontophoenix cunninghamiana \\
\hline Lautenschlager-Rodrigues 2016 & Chelonoidis carbonaria & Artocarpus heterophyllus \\
\hline Lautenschlager-Rodrigues 2016 & Chelonoidis carbonaria & Casearia sylvestris \\
\hline Lautenschlager-Rodrigues 2016 & Chelonoidis carbonaria & Cecropia pachystachya \\
\hline Lautenschlager-Rodrigues 2016 & Chelonoidis carbonaria & Clusia criuva \\
\hline Lautenschlager-Rodrigues 2016 & Chelonoidis carbonaria & Cordia ecalyculata \\
\hline Lautenschlager-Rodrigues 2016 & Chelonoidis carbonaria & Cryptocarya mandioccana \\
\hline Lautenschlager-Rodrigues 2016 & Chelonoidis carbonaria & Eriobotrya japonica \\
\hline Lautenschlager-Rodrigues 2016 & Chelonoidis carbonaria & Eugenia uniflora \\
\hline Lautenschlager-Rodrigues 2016 & Chelonoidis carbonaria & Euterpe edulis \\
\hline Lautenschlager-Rodrigues 2016 & Chelonoidis carbonaria & Genipa americana \\
\hline Lautenschlager-Rodrigues 2016 & Chelonoidis carbonaria & Hymenaea courbaril \\
\hline Lautenschlager-Rodrigues 2016 & Chelonoidis carbonaria & Inga sp. \\
\hline Lautenschlager-Rodrigues 2016 & Chelonoidis carbonaria & Jacaratia spinosa \\
\hline Lautenschlager-Rodrigues 2016 & Chelonoidis carbonaria & Licuala grandis \\
\hline Lautenschlager-Rodrigues 2016 & Chelonoidis carbonaria & Litchi chinensis \\
\hline Lautenschlager-Rodrigues 2016 & Chelonoidis carbonaria & Malpighia sp. \\
\hline Lautenschlager-Rodrigues 2016 & Chelonoidis carbonaria & Melia azedarach \\
\hline Lautenschlager-Rodrigues 2016 & Chelonoidis carbonaria & Ocotea catharinensis \\
\hline Lautenschlager-Rodrigues 2016 & Chelonoidis carbonaria & Philodendron bipinnatifidum \\
\hline Lautenschlager-Rodrigues 2016 & Chelonoidis carbonaria & Plinia cauliflora \\
\hline Lautenschlager-Rodrigues 2016 & Chelonoidis carbonaria & Psidium cattleianum \\
\hline Lautenschlager-Rodrigues 2016 & Chelonoidis carbonaria & Quiina glaziovii \\
\hline Lautenschlager-Rodrigues 2016 & Chelonoidis carbonaria & Sabal maritima \\
\hline Lautenschlager-Rodrigues 2016 & Chelonoidis carbonaria & Spondias purpurea \\
\hline Lautenschlager-Rodrigues 2016 & Chelonoidis carbonaria & Syagrus oleracea \\
\hline Lautenschlager-Rodrigues 2016 & Chelonoidis carbonaria & Syagrus romanzoffiana \\
\hline Lautenschlager-Rodrigues 2016 & Chelonoidis carbonaria & Syzygium cumini \\
\hline Lautenschlager-Rodrigues 2016 & Chelonoidis carbonaria & Talisia esculenta \\
\hline Lautenschlager-Rodrigues 2016 & Chelonoidis carbonaria & Hyophorbe indica \\
\hline Lautenschlager-Rodrigues 2016 & Chelonoidis carbonaria & Cordia africana \\
\hline Leuteritz 2003 & Astrochelys radiata & Clerodendrum perrieri \\
\hline Leuteritz 2003 & Astrochelys radiata & Diospyros myriophylla \\
\hline Leuteritz 2003 & Astrochelys radiata & Operculicarya pachypus \\
\hline Leuteritz 2003 & Astrochelys radiata & Opuntia sp. \\
\hline Leuteritz 2003 & Astrochelys radiata & Lycium acutifolium \\
\hline Leuteritz 2003 & Astrochelys radiata & Sclerocarya birrea \\
\hline Leuteritz 2003 & Astrochelys radiata & Tetraena madagascariensis \\
\hline Limpus and Limpus 2000 & Chelonia mydas & Avicennia marina \\
\hline Limpus and Limpus 2000 & Chelonia mydas & Rhizophora sp. \\
\hline Lingard et. al. 2003 & Astrochelys radiata & Operculicarya decaryi \\
\hline Lingard et. al. 2003 & Astrochelys radiata & Opuntia ficus-indica \\
\hline
\end{tabular}


bioRxiv preprint doi: https://doi org/10.1101/379933; this version posted July 30,2018 . The copyright holder for this preprint (which was not certified by peer review) is the author/funder, who has granted bioRxiv a license to display the preprint in perpetuity. It is made available under aCC-BY-NC-ND 4.0 International license.

Falcón et al. Seed dispersal by chelonians

\begin{tabular}{|c|c|c|}
\hline Lingard et. al. 2003 & Astrochelys radiata & Opuntia monacantha \\
\hline Liu et. al. 2004 & Terrapene carolina & Annona glabra \\
\hline Liu et. al. 2004 & Terrapene carolina & Coccoloba uvifera \\
\hline Liu et. al. 2004 & Terrapene carolina & Coccothrinax argentata \\
\hline Liu et. al. 2004 & Terrapene carolina & Ficus sp. \\
\hline Liu et. al. 2004 & Terrapene carolina & Manilkara zapota \\
\hline Liu et. al. 2004 & Terrapene carolina & Morinda royoc \\
\hline Liu et. al. 2004 & Terrapene carolina & Mosiera longipes \\
\hline Liu et. al. 2004 & Terrapene carolina & Paspalum sp. \\
\hline Liu et. al. 2004 & Terrapene carolina & Smilax havanensis \\
\hline Liu et. al. 2004 & Terrapene carolina & Unidentified Fabaceae \\
\hline Liu et. al. 2004 & Terrapene carolina & Byrsonima lucida \\
\hline Liu et. al. 2004 & Terrapene carolina & Leucothrinax morrisii \\
\hline Liu et. al. 2004 & Terrapene carolina & Setaria sp. \\
\hline Loehr 2002 & Homopus signatus & Antizoma sp. \\
\hline Loehr 2002 & Homopus signatus & Crassula thunbergiana \\
\hline Loehr 2002 & Homopus signatus & Grielum humifusum \\
\hline Loehr 2002 & Homopus signatus & Heliophila variabilis \\
\hline Loehr 2002 & Homopus signatus & Oxalis sp. \\
\hline Macip-Rios et. al. 2010 & Kinosternon integrum & Argemone ochroleuca \\
\hline Macip-Rios et. al. 2010 & Kinosternon integrum & Lemna sp. \\
\hline Macip-Rios et. al. 2010 & Kinosternon integrum & Psidium sp. \\
\hline Macip-Rios et. al. 2010 & Kinosternon integrum & Unidentified Poaceae \\
\hline Milton 1992 & Stigmochelys pardalis & Amaranthus sp. \\
\hline Milton 1992 & Stigmochelys pardalis & Aptosimum indivisum \\
\hline Milton 1992 & Stigmochelys pardalis & Argemone mexicana \\
\hline Milton 1992 & Stigmochelys pardalis & Aristida sp. \\
\hline Milton 1992 & Stigmochelys pardalis & Atriplex lindleyi \\
\hline Milton 1992 & Stigmochelys pardalis & Atriplex semibaccata \\
\hline Milton 1992 & Stigmochelys pardalis & Chamaesyce inequilatera \\
\hline Milton 1992 & Stigmochelys pardalis & Chenopodium sp. \\
\hline Milton 1992 & Stigmochelys pardalis & Chrysocoma ciliata \\
\hline Milton 1992 & Stigmochelys pardalis & Crassula subaphylla \\
\hline Milton 1992 & Stigmochelys pardalis & Cuspidia cernua \\
\hline Milton 1992 & Stigmochelys pardalis & Enneapogon desvauxii \\
\hline Milton 1992 & Stigmochelys pardalis & Enneapogon scaber \\
\hline Milton 1992 & Stigmochelys pardalis & Eragrostis obtusa \\
\hline Milton 1992 & Stigmochelys pardalis & Euphorbia sp. \\
\hline Milton 1992 & Stigmochelys pardalis & Galenia papulosa \\
\hline Milton 1992 & Stigmochelys pardalis & Heliophila sp. \\
\hline Milton 1992 & Stigmochelys pardalis & Hermannia sp. \\
\hline Milton 1992 & Stigmochelys pardalis & Hypertelis salsoloides \\
\hline Milton 1992 & Stigmochelys pardalis & Lepidium sp. \\
\hline Milton 1992 & Stigmochelys pardalis & Lessertia annularis \\
\hline Milton 1992 & Stigmochelys pardalis & Leysera tenella \\
\hline Milton 1992 & Stigmochelys pardalis & Limeum aethiopicum \\
\hline Milton 1992 & Stigmochelys pardalis & Lolium sp. \\
\hline Milton 1992 & Stigmochelys pardalis & Lotononis sp. \\
\hline Milton 1992 & Stigmochelys pardalis & Malva parviflora \\
\hline
\end{tabular}


bioRxiv preprint doi: https://doi.org/10.1101/379933; this version posted July 30, 2018. The copyright holder for this preprint (which was not certified by peer review) is the author/funder, who has granted bioRxiv a license to display the preprint in perpetuity. It is made available under aCC-BY-NC-ND 4.0 International license.

Falcón et al. Seed dispersal by chelonians

\begin{tabular}{|c|c|c|}
\hline Milton 1992 & Stigmochelys pardalis & Medicago polymorpha \\
\hline Milton 1992 & Stigmochelys pardalis & Nemesia sp. \\
\hline Milton 1992 & Stigmochelys pardalis & Osteospermum calendulaceum \\
\hline Milton 1992 & Stigmochelys pardalis & Pleiospilos compactus \\
\hline Milton 1992 & Stigmochelys pardalis & Polygonum sp. \\
\hline Milton 1992 & Stigmochelys pardalis & Sida hederifolia \\
\hline Milton 1992 & Stigmochelys pardalis & Tetragonia echinata \\
\hline Milton 1992 & Stigmochelys pardalis & Tetragonia spicata \\
\hline Milton 1992 & Stigmochelys pardalis & Thesium lineatum \\
\hline Milton 1992 & Stigmochelys pardalis & Tragus sp. \\
\hline Milton 1992 & Stigmochelys pardalis & Trianthema triquetra \\
\hline Milton 1992 & Stigmochelys pardalis & Tribulus terrestris \\
\hline Milton 1992 & Stigmochelys pardalis & Walafrida sp. \\
\hline Milton 1992 & Stigmochelys pardalis & Eriocephalus sp. \\
\hline Milton 1992 & Stigmochelys pardalis & Ursinia sp. \\
\hline Milton 1992 & Stigmochelys pardalis & Tribolium purpureum \\
\hline Milton 1992 & Stigmochelys pardalis & Unidentified Cyperaceae \\
\hline Moldowan et. al. 2016 & Chelydra serpentina & Nuphar variegata \\
\hline Moll 1976 & Graptemys ouachitensis & Ulmus americana \\
\hline Moll 1989 & Dermatemys mawii & Ficus sp. \\
\hline Moll 1989 & Dermatemys mawii & Ficus obtusiuscula \\
\hline Moll and Jansen 1995 & Rhinoclemmys annulata & Astrocaryum alatum \\
\hline Moll and Jansen 1995 & Rhinoclemmys annulata & Faramea suerrensis \\
\hline Moll and Jansen 1995 & Rhinoclemmys annulata & Jacaratia dolichaula \\
\hline Moll and Jansen 1995 & Rhinoclemmys annulata & Solanum siparunoides \\
\hline Moll and Jansen 1995 & Rhinoclemmys funerea & Artocarpus altilis \\
\hline Moll and Jansen 1995 & Rhinoclemmys funerea & Eichhornia crassipes \\
\hline Moll and Jansen 1995 & Rhinoclemmys funerea & Ficus sp. \\
\hline Moll and Jansen 1995 & Rhinoclemmys funerea & Miconia sp. \\
\hline Moll and Jansen 1995 & Rhinoclemmys funerea & Passiflora foetida \\
\hline Moll and Jansen 1995 & Rhinoclemmys annulata & Faramea suerrensis \\
\hline Moll and Jansen 1995 & Rhinoclemmys annulata & Ficus sp. \\
\hline Moll and Jansen 1995 & Rhinoclemmys annulata & Jacaratia dolichaula \\
\hline Moll and Jansen 1995 & Rhinoclemmys annulata & Miconia affinis \\
\hline Moll and Jansen 1995 & Rhinoclemmys annulata & Sonneratia sp. \\
\hline Moll and Jansen 1995 & Rhinoclemmys funerea & Cecropia sp. \\
\hline Moll and Jansen 1995 & Rhinoclemmys funerea & Dieffenbachia longispatha \\
\hline Moll and Jansen 1995 & Rhinoclemmys funerea & Ficus insipida \\
\hline Moll and Jansen 1995 & Rhinoclemmys funerea & Ipomoea trifida \\
\hline Moll and Jansen 1995 & Rhinoclemmys funerea & Solanum pimpinellifolium \\
\hline Moll and Jansen 1995 & Rhinoclemmys funerea & Spondias mombin \\
\hline Moolna 2007 & Aldabrachelys gigantea & Diospyros egrettarum \\
\hline Moskovits and Bjorndal 1990 & Chelonoidis carbonaria & Annona sp1. \\
\hline Moskovits and Bjorndal 1990 & Chelonoidis carbonaria & Annona sp2. \\
\hline Moskovits and Bjorndal 1990 & Chelonoidis carbonaria & Bagassa guianensis \\
\hline Moskovits and Bjorndal 1990 & Chelonoidis carbonaria & Duguetia surinamensis \\
\hline Moskovits and Bjorndal 1990 & Chelonoidis carbonaria & Ecclinusa guianensis \\
\hline Moskovits and Bjorndal 1990 & Chelonoidis carbonaria & Ficus sp. \\
\hline Moskovits and Bjorndal 1990 & Chelonoidis carbonaria & Genipa americana \\
\hline
\end{tabular}


bioRxiv preprint doi: https://doi.org/10.1101/379933; this version posted July 30, 2018. The copyright holder for this preprint (which was not certified by peer review) is the author/funder, who has granted bioRxiv a license to display the preprint in perpetuity. It is made available under aCC-BY-NC-ND 4.0 International license.

Falcón et al. Seed dispersal by chelonians

Moskovits and Bjorndal 1990

Moskovits and Bjorndal 1990

Moskovits and Bjorndal 1990

Moskovits and Bjorndal 1990

Moskovits and Bjorndal 1990

Moskovits and Bjorndal 1990

Moskovits and Bjorndal 1990

Moskovits and Bjorndal 1990

Moskovits and Bjorndal 1990

Moskovits and Bjorndal 1990

Moskovits and Bjorndal 1990

Moskovits and Bjorndal 1990

Moskovits and Bjorndal 1990

Moskovits and Bjorndal 1990

Moskovits and Bjorndal 1990

Moskovits and Bjorndal 1990

Moskovits and Bjorndal 1990

Moskovits and Bjorndal 1990

Moskovits and Bjorndal 1990

Moskovits and Bjorndal 1990

Moskovits and Bjorndal 1990

Moskovits and Bjorndal 1990

Moskovits and Bjorndal 1990

Moskovits and Bjorndal 1990

Moskovits and Bjorndal 1990

Moskovits and Bjorndal 1990

Moskovits and Bjorndal 1990

Moskovits and Bjorndal 1990

Moskovits and Bjorndal 1990

Moskovits and Bjorndal 1990

Moskovits and Bjorndal 1990

Moskovits and Bjorndal 1990

Moskovits and Bjorndal 1990

Moskovits and Bjorndal 1990

Moskovits and Bjorndal 1990

Moskovits and Bjorndal 1990

Moskovits and Bjorndal 1990

Moskovits and Bjorndal 1990

Moskovits and Bjorndal 1990

Moskovits and Bjorndal 1990

Moskovits and Bjorndal 1990

Moskovits and Bjorndal 1990

Moskovits and Bjorndal 1990

Moskovits and Bjorndal 1990

Moskovits and Bjorndal 1990

Moskovits and Bjorndal 1990

Moskovits and Bjorndal 1990

Moskovits and Bjorndal 1990

Moskovits and Bjorndal 1990
Chelonoidis carbonaria

Chelonoidis carbonaria

Chelonoidis carbonaria

Chelonoidis carbonaria

Chelonoidis carbonaria

Chelonoidis carbonaria

Chelonoidis carbonaria

Chelonoidis carbonaria

Chelonoidis carbonaria

Chelonoidis carbonaria

Chelonoidis carbonaria

Chelonoidis carbonaria

Chelonoidis carbonaria

Chelonoidis carbonaria

Chelonoidis carbonaria

Chelonoidis carbonaria

Chelonoidis carbonaria

Chelonoidis carbonaria

Chelonoidis carbonaria

Chelonoidis carbonaria

Chelonoidis carbonaria

Chelonoidis carbonaria

Chelonoidis carbonaria

Chelonoidis carbonaria

Chelonoidis carbonaria

Chelonoidis carbonaria

Chelonoidis carbonaria

Chelonoidis carbonaria

Chelonoidis carbonaria

Chelonoidis carbonaria

Chelonoidis carbonaria

Chelonoidis denticulata

Chelonoidis denticulata

Chelonoidis denticulata

Chelonoidis denticulata

Chelonoidis denticulata

Chelonoidis denticulata

Chelonoidis denticulata

Chelonoidis denticulata

Chelonoidis denticulata

Chelonoidis denticulata

Chelonoidis denticulata

Chelonoidis denticulata

Chelonoidis denticulata

Chelonoidis denticulata

Chelonoidis denticulata

Chelonoidis denticulata

Chelonoidis denticulata

Chelonoidis denticulata
Geophila repens

Guettarda argentea

Mauritia flexuosa

Myriaspora egensis

Passiflora sp.

Philodendron sp.

Spondias mombin

Trattinnickia ravifolia

Anacardium giganteum

Bagassa guianensis

Bromelia sp.

Brosimum potabile

Clavija sp.

Desmoncus polyacanthos

Duguetia surinamensis

Duroia eriopila

Ficus sp.

Guettarda argentea

Licania kunthiana

Mauritia flexuosa

Myriaspora egensis

Passiflora coccinea

Passiflora vespertilio

Philodendron sp.

Posoqueria sp.

Pouteria sp.

Pradosia sp.

Spondias mombin

Richardela sp.

Ecclinusa guianensis

Unidentified Lecythidaceae

Annona sp1.

Annona sp2.

Bagassa guianensis

Duguetia surinamensis

Ecclinusa guianensis

Ficus sp.

Genipa americana

Geophila repens

Guettarda argentea

Mauritia flexuosa

Myriaspora egensis

Passiflora sp.

Philodendron sp.

Spondias mombin

Trattinnickia sp.

Anacardium giganteum

Bagassa guianensis

Bromelia sp. 
bioRxiv preprint doi: https://doi.org/10.1101/379933; this version posted July 30, 2018. The copyright holder for this preprint (which was not certified by peer review) is the author/funder, who has granted bioRxiv a license to display the preprint in perpetuity. It is made available under aCC-BY-NC-ND 4.0 International license.

Falcón et al. Seed dispersal by chelonians

\begin{tabular}{|c|c|c|}
\hline Moskovits and Bjorndal 1990 & Chelonoidis denticulata & Brosimum potabile \\
\hline Moskovits and Bjorndal 1990 & Chelonoidis denticulata & Clavija sp. \\
\hline Moskovits and Bjorndal 1990 & Chelonoidis denticulata & Desmoncus polyacanthos \\
\hline Moskovits and Bjorndal 1990 & Chelonoidis denticulata & Duguetia surinamensis \\
\hline Moskovits and Bjorndal 1990 & Chelonoidis denticulata & Duroia eriopila \\
\hline Moskovits and Bjorndal 1990 & Chelonoidis denticulata & Ficus sp. \\
\hline Moskovits and Bjorndal 1990 & Chelonoidis denticulata & Guettarda argentea \\
\hline Moskovits and Bjorndal 1990 & Chelonoidis denticulata & Licania kunthiana \\
\hline Moskovits and Bjorndal 1990 & Chelonoidis denticulata & Mauritia flexuosa \\
\hline Moskovits and Bjorndal 1990 & Chelonoidis denticulata & Myriaspora egensis \\
\hline Moskovits and Bjorndal 1990 & Chelonoidis denticulata & Passiflora coccinea \\
\hline Moskovits and Bjorndal 1990 & Chelonoidis denticulata & Passiflora vespertilio \\
\hline Moskovits and Bjorndal 1990 & Chelonoidis denticulata & Philodendron sp. \\
\hline Moskovits and Bjorndal 1990 & Chelonoidis denticulata & Posoqueria sp. \\
\hline Moskovits and Bjorndal 1990 & Chelonoidis denticulata & Pouteria sp. \\
\hline Moskovits and Bjorndal 1990 & Chelonoidis denticulata & Pradosia sp. \\
\hline Moskovits and Bjorndal 1990 & Chelonoidis denticulata & Spondias mombin \\
\hline Moskovits and Bjorndal 1990 & Chelonoidis denticulata & Richardella sp. \\
\hline Moskovits and Bjorndal 1990 & Chelonoidis denticulata & Ecclinusa guianensis \\
\hline Moskovits and Bjorndal 1990 & Chelonoidis denticulata & Unidentified Lecythidaceae \\
\hline Murray and Wolf 2013 & Gopherus agassizii & Opuntia sp. \\
\hline Padgett et. al. 2012 & Chrysemys picta & Carex sp. \\
\hline Padgett et. al. 2012 & Chrysemys picta & Decodon verticillatus \\
\hline Padgett et. al. 2012 & Chrysemys picta & Najas flexilis \\
\hline Padgett et. al. 2012 & Chrysemys picta & Nuphar variegata \\
\hline Padgett et. al. 2012 & Chrysemys picta & Nymphaea odorata \\
\hline Padgett et. al. 2012 & Chrysemys picta & Potamogeton sp. \\
\hline Padgett et. al. 2012 & Chrysemys picta & Bidens sp. \\
\hline Padgett et. al. 2012 & Chrysemys picta & Unidentified Poaceae \\
\hline Pemberton and Gilchrist 2009 & Aldabrachelys gigantea & Artocarpus altilis \\
\hline Pemberton and Gilchrist 2009 & Aldabrachelys gigantea & Xylocarpus moluccensis \\
\hline Perez-Eman and Paolillo 1997 & Peltocephalus dumerilianus & Annona glabra \\
\hline Perez-Eman and Paolillo 1997 & Peltocephalus dumerilianus & Combretum laxum \\
\hline Perez-Eman and Paolillo 1997 & Peltocephalus dumerilianus & Eperua purpurea \\
\hline Perez-Eman and Paolillo 1997 & Peltocephalus dumerilianus & Hevea benthamiana \\
\hline Perez-Eman and Paolillo 1997 & Peltocephalus dumerilianus & Leopoldinia piassaba \\
\hline Perez-Eman and Paolillo 1997 & Peltocephalus dumerilianus & Leopoldinia pulchra \\
\hline Perez-Eman and Paolillo 1997 & Peltocephalus dumerilianus & Macrolobium multijugum \\
\hline Perez-Eman and Paolillo 1997 & Peltocephalus dumerilianus & Macrolobium sp. \\
\hline Perez-Eman and Paolillo 1997 & Peltocephalus dumerilianus & Maripa paniculata \\
\hline Perez-Eman and Paolillo 1997 & Peltocephalus dumerilianus & Mauritia flexuosa \\
\hline Perez-Eman and Paolillo 1997 & Peltocephalus dumerilianus & Mauritiella aculeata \\
\hline Perez-Eman and Paolillo 1997 & Peltocephalus dumerilianus & Parahancornia negroensis \\
\hline Perez-Eman and Paolillo 1997 & Peltocephalus dumerilianus & Parinari campestris \\
\hline Perez-Eman and Paolillo 1997 & Peltocephalus dumerilianus & Rauvolfia polyphylla \\
\hline Perez-Eman and Paolillo 1997 & Peltocephalus dumerilianus & Swartzia sericea \\
\hline Perez-Eman and Paolillo 1997 & Peltocephalus dumerilianus & Compsiandra comosa \\
\hline Perez-Eman and Paolillo 1997 & Peltocephalus dumerilianus & Macrolobium angustifolium \\
\hline Perez-Eman and Paolillo 1997 & Peltocephalus dumerilianus & Unidentified Lauraceae \\
\hline
\end{tabular}


bioRxiv preprint doi: https://doi.org/10.1101/379933; this version posted July 30,2018. The copyright holder for this preprint (which was not certified by peer review) is the author/funder, who has granted bioRxiv a license to display the preprint in perpetuity. It is made available under aCC-BY-NC-ND 4.0 International license.

Falcón et al. Seed dispersal by chelonians

Platt et. al. 2009

Platt et. al. 2009

Platt et. al. 2009

Platt et. al. 2009

Platt et. al. 2009

Platt et. al. 2009

Platt et. al. 2009

Platt et. al. 2009

Platt et. al. 2009

Platt et. al. 2009

Platt et. al. 2010

Platt et. al. 2010

Platt et. al. 2010

Platt et. al. 2014a

Platt et. al. 2014a

Platt et. al. 2014b

Platt et. al. 2016

Platt et. al. 2016

Plummer and Farrar 1981

Plummer and Farrar 1981

Plummer and Farrar 1981

Plummer and Farrar 1981

Raney and Rachner 1942

Rasoma et. al. 2013

Rasoma et. al. 2013

Rasoma et. al. 2013

Rasoma et. al. 2013

Rasoma et. al. 2013

Renvoize 1971

Rick and Bowman 1961

Rouag et. al. 2008

Rouag et. al. 2008

Rouag et. al. 2008

Rouag et. al. 2008

Rust and Roth 1981

Santos-Júnior 2009

Santos-Júnior 2009

Santos-Júnior 2009

Santos-Júnior 2009

Santos-Júnior 2009

Setlalekgomo and Sesiny 2014

Setlalekgomo and Sesinyi 2014

Snider 1993

Stone and Moll 2006

Stone and Moll 2006

Stone and Moll 2006

Stone and Moll 2006

Stone and Moll 2006

Stone and Moll 2006
Terrapene carolina bauri

Terrapene carolina bauri

Terrapene carolina bauri

Terrapene carolina bauri

Terrapene carolina bauri

Terrapene carolina bauri

Terrapene carolina bauri

Terrapene carolina bauri

Terrapene carolina bauri

Terrapene carolina bauri

Heosemys depressa

Heosemys depressa

Heosemys depressa

Vijayachelys silvatica

Vijayachelys silvatica

Heosemys depressa

Kinosternon hirtipes

Kinosternon hirtipes

Apalone mutica

Apalone mutica

Apalone mutica

Apalone mutica

Chrysemys picta

Astrochelys radiata

Astrochelys radiata

Astrochelys radiata

Astrochelys radiata

Astrochelys radiata

Aldabrachelys gigantea

Chelonoidis porteri

Testudo graeca

Testudo graeca

Testudo graeca

Testudo graeca

Terrapene carolina

Podocnemis erythrocephala

Podocnemis erythrocephala

Podocnemis erythrocephala

Podocnemis erythrocephala

Podocnemis erythrocephala

Psammobates oculifer

Psammobates oculifer

Gopherus agassizii

Terrapene carolina

Terrapene carolina

Terrapene carolina

Terrapene ornata

Terrapene ornata

Terrapene ornata

\section{Annona glabra}

Byrsonima lucida

Coccoloba uvifera

Coccothrinax argentata

Ficus sp.

Morinda royoc

Mosiera longipes

Socratea exorrhiza

Leucothrinax morrisii

Unidentified Fabaceae

Ficus hispida

Erythrina suberosa

Grewia nervosa

Dillenia pentagyna

Salacca sp.

Dillenia pentagyna

Paspalum distichum

Prosopis glandulosa

Morus sp.

Populus deltoides

Morus sp.

Populus sp.

Nuphar variegata

Gyrocarpus americanus

Paederia grandidieri

Radamaea montana

Salvadora angustifolia

Olax dissitiflora

Pandanus tectorius

Solanum siparunoides

Anagallis minima

Linaria pinifolia

Tuberaria guttata

Coronilla scorpioides

Podophyllum peltatum

Pouteria sp.

Posoqueria sp.

Smilax coriacea

Unidentified Fabaceae

Unidentified Poaceae

Grewia flavescens

Unidentified

Opuntia engelmannii

Fragaria sp.

Podophyllum peltatum

Rubus allegheniensis

Fragaria sp.

Podophyllum peltatum

Rubus allegheniensis 
bioRxiv preprint doi: https://doi org/10.1101/379933; this version posted July 30,2018 . The copyright holder for this preprint (which was not certified by peer review) is the author/funder, who has granted bioRxiv a license to display the preprint in perpetuity. It is made available under aCC-BY-NC-ND 4.0 International license.

Falcón et al. Seed dispersal by chelonians

\begin{tabular}{|c|c|c|}
\hline Stone and Moll 2009 & Terrapene carolina & Ambrosia artemisiifolia \\
\hline Stone and Moll 2009 & Terrapene carolina & Celtis sp. \\
\hline Stone and Moll 2009 & Terrapene carolina & Cornus sp. \\
\hline Stone and Moll 2009 & Terrapene carolina & Fragaria virginiana \\
\hline Stone and Moll 2009 & Terrapene carolina & Morus sp. \\
\hline Stone and Moll 2009 & Terrapene carolina & Passiflora sp. \\
\hline Stone and Moll 2009 & Terrapene carolina & Phytolacca americana \\
\hline Stone and Moll 2009 & Terrapene carolina & Platanus occidentalis \\
\hline Stone and Moll 2009 & Terrapene carolina & Podophyllum peltatum \\
\hline Stone and Moll 2009 & Terrapene carolina & Rubus sp. \\
\hline Stone and Moll 2009 & Terrapene carolina & Vaccinium sp. \\
\hline Stone and Moll 2009 & Terrapene carolina & Vitis sp. \\
\hline Stone and Moll 2009 & Terrapene carolina & Unidentified Polygonaceae \\
\hline Stone and Moll 2009 & Terrapene carolina & Unidentified \\
\hline Stone and Moll 2009 & Terrapene ornata & Fragaria virginiana \\
\hline Stone and Moll 2009 & Terrapene ornata & Galium sp. \\
\hline Stone and Moll 2009 & Terrapene ornata & Morus sp. \\
\hline Stone and Moll 2009 & Terrapene ornata & Prunus sp. \\
\hline Stone and Moll 2009 & Terrapene ornata & Rubus sp. \\
\hline Stone and Moll 2009 & Terrapene ornata & Unidentified Polygonaceae \\
\hline Stone and Moll 2009 & Terrapene ornata & Unidentified Poaceae \\
\hline Stone and Moll 2009 & Terrapene ornata & Unidentified Cyperaceae \\
\hline Strong and Fragoso 2006 & Chelonoidis carbonaria & Aechmea sp. \\
\hline Strong and Fragoso 2006 & Chelonoidis carbonaria & Ficus sp. \\
\hline Strong and Fragoso 2006 & Chelonoidis carbonaria & Genipa americana \\
\hline Strong and Fragoso 2006 & Chelonoidis denticulata & Aechmea sp. \\
\hline Strong and Fragoso 2006 & Chelonoidis denticulata & Ficus sp. \\
\hline Strong and Fragoso 2006 & Chelonoidis denticulata & Genipa americana \\
\hline Sung et. al. 2016 & Platysternon megacephalum & Ficus sp. \\
\hline Sung et. al. 2016 & Platysternon megacephalum & Machilus breviflora \\
\hline Sung et. al. 2016 & Platysternon megacephalum & Machilus thunbergii \\
\hline Sung et. al. 2016 & Platysternon megacephalum & Turpinia arguta \\
\hline Teran et. al. 1995 & Phrynops geoffroanus & Diospyros sp. \\
\hline Teran et. al. 1995 & Phrynops geoffroanus & Margaritaria nobilis \\
\hline Teran et. al. 1995 & Phrynops geoffroanus & Maripa sp. \\
\hline Teran et. al. 1995 & Phrynops geoffroanus & Pouteria sp. \\
\hline Teran et. al. 1995 & Phrynops geoffroanus & Unidentified Fabaceae \\
\hline Tol et. al. 2017 & Chelonia mydas & Halodule uninervis \\
\hline Tol et. al. 2017 & Chelonia mydas & Halophila decipiens \\
\hline Tol et. al. 2017 & Chelonia mydas & Zostera muelleri \\
\hline Tulipani and Lipcius 2014 & Malaclemys terrapin & Zostera marina \\
\hline Turner et. al. 1984 & Gopherus agassizii & Opuntia sp. \\
\hline van Dijk 1998 & Indotestudo elongata & Cyanotis cristata \\
\hline van Dijk 1998 & Indotestudo elongata & Dillenia sp. \\
\hline van Dijk 1998 & Indotestudo elongata & Ficus racemosa \\
\hline van Dijk 1998 & Indotestudo elongata & Olax scandens \\
\hline Varela and Bucher 2002 & Chelonoidis chilensis & Celtis pallida \\
\hline Varela and Bucher 2002 & Chelonoidis chilensis & Prosopis elata \\
\hline Varela and Bucher 2002 & Chelonoidis chilensis & Prosopis nigra \\
\hline
\end{tabular}


bioRxiv preprint doi: https://doi org/10.1101/379933; this version posted July 30,2018. The copyright holder for this preprint (which was not certified by peer review) is the author/funder, who has granted bioRxiv a license to display the preprint in perpetuity. It is made available under aCC-BY-NC-ND 4.0 International license.

Falcón et al. Seed dispersal by chelonians

\begin{tabular}{|c|c|c|}
\hline Varela and Bucher 2002 & Chelonoidis chilensis & Prosopis torquata \\
\hline Varela and Bucher 2002 & Chelonoidis chilensis & Ziziphus mistol \\
\hline Varela and Bucher 2002 & Chelonoidis chilensis & Celtis pallida \\
\hline Varela and Bucher 2002 & Chelonoidis chilensis & Ziziphus mistol \\
\hline Veerappan and Vasudevan 2012 & Indotestudo travancorica & Dillenia pentagyna \\
\hline Vijaya 1982 & Indotestudo forsteni & Artocarpus heterophyllus \\
\hline Vijaya 1982 & Vijayachelys silvatica & Artocarpus heterophyllus \\
\hline Vijaya 1982 & Vijayachelys silvatica & Dillenia pentagyna \\
\hline Vijaya 1982 & Vijayachelys silvatica & Cordia peruviana \\
\hline Vijaya 1983 & Indotestudo travancorica & Artocarpus heterophyllus \\
\hline Vijaya 1983 & Indotestudo travancorica & Dillenia pentagyna \\
\hline Vogt and Guzmán 1988 & Kinosternon leucostomum & Ficus sp. \\
\hline Vogt and Guzmán 1988 & Kinosternon leucostomum & Piper sp. \\
\hline Vogt and Guzmán 1988 & Kinosternon leucostomum & Pulcheni armata \\
\hline Vogt and Guzmán 1988 & Staurotypus triporcatus & Diospyros nigra \\
\hline Vogt et. al. 2009 & Rhinoclemmys aerolata & Byrsonima crassifolia \\
\hline Vogt et. al. 2009 & Rhinoclemmys aerolata & Eugenia sp. \\
\hline Vogt et. al. 2009 & Rhinoclemmys aerolata & Miconia sp. \\
\hline Waibel et. al. 2012 & Aldabrachelys gigantea & Lantana camara \\
\hline Waibel et. al. 2012 & Aldabrachelys gigantea & Mimusops coriacea \\
\hline Waibel et. al. 2012 & Aldabrachelys gigantea & Wikstroemia indica \\
\hline Waibel et. al. 2012 & Aldabrachelys gigantea & Adonidia merrillii \\
\hline Waller at. al. 1989 & Chelonoidis chilensis & Goldmanceggea glauca \\
\hline Waller et. al. 1989 & Chelonoidis chilensis & Cereus aethiops \\
\hline Waller et. al. 1989 & Chelonoidis chilensis & Daucus pusillus \\
\hline Waller et. al. 1989 & Chelonoidis chilensis & Geoffroea decorticans \\
\hline Waller et. al. 1989 & Chelonoidis chilensis & Monttea aphylla \\
\hline Waller et. al. 1989 & Chelonoidis chilensis & Plantago patagonica \\
\hline Waller et. al. 1989 & Chelonoidis chilensis & Prosopis alpataco \\
\hline Waller et. al. 1989 & Chelonoidis chilensis & Schismus barbatus \\
\hline Wang et. al. 2011 & Chelonoidis carbonaria & Acrocomia aculeata \\
\hline Wang et. al. 2011 & Chelonoidis carbonaria & Agonandra brasiliensis \\
\hline Wang et. al. 2011 & Chelonoidis carbonaria & Annona cornifolia \\
\hline Wang et. al. 2011 & Chelonoidis carbonaria & Annona dioica \\
\hline Wang et. al. 2011 & Chelonoidis carbonaria & Ficus sp. \\
\hline Wang et. al. 2011 & Chelonoidis carbonaria & Genipa americana \\
\hline Wang et. al. 2011 & Chelonoidis carbonaria & Hancornia speciosa \\
\hline Wang et. al. 2011 & Chelonoidis carbonaria & Mouriri elliptica \\
\hline Wang et. al. 2011 & Chelonoidis carbonaria & Pouteria gardneri \\
\hline Wang et. al. 2011 & Chelonoidis carbonaria & Protium heptaphyllum \\
\hline Wang et. al. 2011 & Chelonoidis carbonaria & Psidium nutans \\
\hline Wang et. al. 2011 & Chelonoidis carbonaria & Psidium guajava \\
\hline Wang et. al. 2011 & Chelonoidis carbonaria & Syagrus flexuosa \\
\hline Wang et. al. 2011 & Chelonoidis carbonaria & Syzygium cumini \\
\hline Wang et. al. 2011 & Chelonoidis carbonaria & Vitex cymosa \\
\hline Wang et. al. 2011 & Chelonoidis carbonaria & Cordiera sessilis \\
\hline Wang et. al. 2011 & Chelonoidis carbonaria & Byrsonima cydoniifolia \\
\hline Whitaker 2009 & Vijayachelys silvatica & Ficus pertusa \\
\hline Wilson and Lawler 2008 & Emydura macquarii krefftii & Ficus sp. \\
\hline
\end{tabular}


bioRxiv preprint doi: https://doi.org/10,1101/379933; this version posted July 30, 2018. The copyright holder for this preprint (which was not certified by peer review) is the author/funder, who has granted bioRxiv a license to display the preprint in perpetuity. It is made available under aCC-BY-NC-ND 4.0 International license.

Falcón et al. Seed dispersal by chelonians 
Falcón et al. Seed dispersal by chelonians

S3: Studies from which data on the gut retention times (GRT) of chelonians were extracted, and chelonian mean GRT and mass. ' $N A$ ' indicates that the mean GRT was not available (only the range; see Fig. 6).

\begin{tabular}{|c|c|c|c|}
\hline Reference & Chelonian species & Mean GRT (d) & Mass (kg) \\
\hline Amorocho \& Reina 2008 & Chelonia mydas & 23.7 & 160.0 \\
\hline Andriantsaralaza et al. 2013 & Aldabrachelys gigantea & $N A$ & 117.2 \\
\hline Barboza 1995 & Gopherus agassizii & 10.8 & 2.8 \\
\hline Bjorndal 1987 & Gopherus polyphemus & 13.0 & 4.1 \\
\hline Bjorndal 1989 & Chelonoidis carbonaria & 2.6 & 2.0 \\
\hline Bjorndal 1989 & Chelonoidis denticulata & 3.6 & 2.0 \\
\hline Bjorndal 1990 & Pseudemys nelsoni & 2.8 & 3.8 \\
\hline Bjorndal and Bolten 1993 & Pseudemys nelsoni & 3.1 & 3.8 \\
\hline Bjorndal and Bolten 1993 & Trachemys scripta & 4.9 & 1.9 \\
\hline Blake et al. 2012 & Chelonoidis nigra & 12.0 & 175.0 \\
\hline Braun \& Brooks 1987 & Terrapene carolina & $N A$ & 0.4 \\
\hline Davenport et al. 1992 & Batagur baska & NA & 17.9 \\
\hline Elbers 2010 & Macrochelys temminckii & $N A$ & 78.9 \\
\hline Falcón et al. unpubl. & Aldabrachelys gigantea & 15.0 & 117.2 \\
\hline Franz et al. 2011 & Aldabrachelys gigantea & 6.8 & 117.2 \\
\hline Franz et al. 2011 & Centrochelys sulcata & 15.9 & 43.0 \\
\hline Franz et al. 2011 & Chelonoidis nigra & 8.6 & 175.0 \\
\hline Franz et al. 2011 & Testudo graeca & 6.8 & 1.4 \\
\hline Franz et al. 2011 & Testudo hermanni & 5.0 & 1.3 \\
\hline Guzmán \& Stevenson 2008 & Chelonoidis denticulata & 21.0 & 2.0 \\
\hline Hailey 1997 & Kinixys spekii & 5.6 & 0.6 \\
\hline Hailey 1997 & Stigmochelys pardalis & 5.2 & 20.0 \\
\hline Hailey 1998 & Kinixys spekii & 5.5 & 0.6 \\
\hline Hamilton and Coe 1982 & Aldabrachelys gigantea & 12.2 & 117.2 \\
\hline Hansen et al. 2008 & Aldabrachelys gigantea & 14.0 & 117.2 \\
\hline Hatt et al. 2002 & Chelonoidis nigra & 10.2 & 175.0 \\
\hline Jansen \& Moll 1995 & Rhinoclemmys annulata & 1.5 & 1.4 \\
\hline Jansen \& Moll 1995 & Rhinoclemmys funerea & 1.8 & 0.9 \\
\hline Jerozolimski et al. 2009 & Chelonoidis denticulata & 8.3 & 2.0 \\
\hline Kimmons \& Moll 2010 & Chelydra serpentina & 2.0 & 5.2 \\
\hline Kimmons \& Moll 2010 & Chelydra serpentina & 2.0 & 5.2 \\
\hline Kimmons \& Moll 2010 & Chelydra serpentina & 2.3 & 5.2 \\
\hline Kimmons \& Moll 2010 & Trachemys scripta & 2.8 & 1.9 \\
\hline Kimmons \& Moll 2010 & Trachemys scripta & 2.9 & 1.9 \\
\hline Kimmons \& Moll 2010 & Trachemys scripta & 3.7 & 1.9 \\
\hline Lautenschlager-Rodrigues 2016 & Chelonoidis carbonaria & 6.9 & 2.0 \\
\hline Legler \& Vogt 2013 & Rhinoclemmys aereolata & 3.0 & 0.7 \\
\hline Lickel 2010 & Stigmochelys pardalis & 15.8 & 20.0 \\
\hline Meienberger et al. 1993 & Gopherus agassizii & 21.5 & 2.8 \\
\hline Parmenter 1981 & Chelydra serpentina & 1.3 & 5.2 \\
\hline Parmenter 1981 & Chrysemys picta & 2.5 & 0.4 \\
\hline Parmenter 1981 & Chrysemys scripta & 2.5 & 0.4 \\
\hline Parmenter 1981 & Sternotherus minor & 2.4 & 0.2 \\
\hline Parmenter 1981 & Sternotherus odoratus & 2.0 & 0.1 \\
\hline
\end{tabular}


Falcón et al. Seed dispersal by chelonians

\begin{tabular}{llll}
\hline Rick \& Bowman 1961 & Chelonoidis porteri & NA & 175.0 \\
Sadeghayobi et al. 2011 & Chelonoidis nigra & 10.1 & 175.0 \\
Setlalekgomo \& Sesiny 2014 & Psammobates oculifer & NA & 0.3 \\
Setlalekgomo and Sesinyi 2014 & Psammobates oculifer & 4.0 & 0.3 \\
Stone \& Moll 2006 & Terrapene carolina & NA & 0.4 \\
Stone \& Moll 2006 & Terrapene ornata & NA & 0.4 \\
Tracy et al. 2006 & Gopherus agassizii & 9.5 & 2.8 \\
Valente et al. 2008 & Caretta caretta & 11.5 & 109.2 \\
Varela \& Bucher 2002 & Chelonoidis chilensis & 8.0 & 3.2 \\
Waibel et al. 2012 & Aldabrachelys gigantea & 15.5 & 117.2 \\
\hline \hline
\end{tabular}

S4: Studies from which data on the home range size of chelonians were extracted, and chelonian mean home range and mass. See Figure 7a for ranges (minimum and maximum home range size).

\begin{tabular}{llll}
\hline \hline Reference & Chelonian species & Home range (ha) & Mass (kg) \\
\hline Barret 1990 & Gopherus agassizii & 19.0 & 2.8 \\
Baxter 2015 & Aldabrachelys gigantea & 10.5 & 117.2 \\
Bernstein et al. 2007 & Terrapene ornata & 5.8 & 0.4 \\
Bridget and Echternacht 2009 & Terrapene carolina & 2.3 & 0.4 \\
Carter et al. 1999 & Clemmys muhlenbergii & 0.5 & 0.2 \\
Chase et al. 1989 & Clemmys muhlenbergii & 0.1 & 0.2 \\
Diemer 1992 & Gopherus polyphemus & 0.9 & 4.1 \\
Doroff and Keith 1990 & Terrapene ornata & 8.7 & 0.4 \\
Duda et al. 1999 & Gopherus agassizii & 12.5 & 2.8 \\
Edge et al. 2015 & Emydoidea blandingii & 59.2 & 1.2 \\
Eubanks et al. 2003 & Gopherus polyphemus & 0.8 & 4.1 \\
Forero-Medina et al. 2012 & Mesoclemmys dahli & 15.3 & 0.8 \\
Franks et al. 2011 & Gopherus agassizii & 7.3 & 2.8 \\
Galois et al. 2002 & Apalone spinifera & 24.2 & 4.8 \\
Geffen and Mendelssohn 1988 & Testudo kleinmanni & 26.4 & 0.4 \\
Hailey and Coulson 1996 & Kinixys spekii & 1.9 & 0.6 \\
Hailey and Coulson 1996 & Stigmochelys pardalis & 26.0 & 20.0 \\
Innes et al. 2008 & Emydoidea blandingii & 4.9 & 1.2 \\
Jones 1996 & Graptemys flavimaculata & 3.5 & 0.9 \\
Judd and Rose 1983 & Gopherus berlandieri & 0.4 & 1.8 \\
Lawson 2006 & Kinixys erosa & 14.2 & 1.1 \\
Lawson 2006 & Kinixys homeana & 20.0 & 1.1 \\
Litzgus and Mousseau 2004 & Clemmys guttata & 7.5 & 0.2 \\
Lue and Chen 1999 & Cuora flavomarginata & 1.1 & 0.5 \\
Mazzotti et al. 2002 & Testudo hermanni & 6.0 & 1.3 \\
McMaster and Downs 2009 & Stigmochelys pardalis & 122.4 & 20.0 \\
Millar and Blouin-Demers 2011 & Emydoidea blandingii & 12.0 & 1.2 \\
Morrow et al. 2001 & Clemmys muhlenbergii & 0.6 & 0.2 \\
Moskovits and Kiester 1987 & Chelonoidis carbonaria & 26.3 & 2.0 \\
Moskovits and Kiester 1987 & Chelonoidis denticulata & 36.1 & 2.0 \\
Nieuwot 1996 & Terrapene ornata & 1.6 & 0.4 \\
O'connor et al. 1994 & Gopherus agassizii & 27.3 & 2.8 \\
Obbard and Brooks 1981 & Chelydra serpentina & 3.5 & 5.2 \\
Roe and Arthur 2008 & Chelodina longicolis & 11.5 & 1.3 \\
\hline \hline
\end{tabular}


bioRxiv preprint doi: https://doi org/101101/379933; this version posted July 30,2018. The copyright holder for this preprint (which was not certified by peer review) is the author/funder, who has granted bioRxiv a license to display the preprint in perpetuity. It is made available under aCC-BY-NC-ND 4.0 International license.

Falcón et al. Seed dispersal by chelonians

\begin{tabular}{llll} 
Ross and Anderson 1990 & Emydoidea blandingii & 0.6 & 1.2 \\
Rowe 2003 & Chrysemys picta & 1.2 & 0.4 \\
Rowe and Moll 1991 & Emydoidea blandingii & 84.5 & 1.2 \\
Seminoff et al. 2002 & Chelonia mydas & 1662.0 & 160.0 \\
Smith and Cherry 2016 & Glyptemys muhlenbergii & 0.8 & 0.1 \\
Stickel 1989 & Terrapene carolina & 1.2 & 0.4 \\
Strang 1983 & Clemmys insculpta & 0.0 & 0.2 \\
Strang 1983 & Terrapene carolina & 0.0 & 0.4 \\
\hline \hline
\end{tabular}


Falcón et al. Seed dispersal by chelonians

S5: Studies from which data on the displacement distances of chelonians were extracted, and chelonian mean displacement distance and mass. ' $N A$ ' indicates that the mean displacement distance was not available (only the range; see Fig. $7 \mathrm{~b}$ ).

\begin{tabular}{llll}
\hline \hline Reference & Chelonian species & Displacement $\mathbf{~ ( m ~ d ~}^{-\mathbf{1}}$ ) & Mass (kg) \\
\hline Baxter 2015 & Aldabrachelys gigantea & 191.8 & 117.2 \\
Birkhead et al. 2005 & Gopherus polyphemus & NA & 4.1 \\
Brown and Brooks 1993 & Chelydra serpentina & 300.5 & 5.2 \\
Díaz-Paniagua & Testudo graeca & 50.0 & 1.4 \\
Duda et al. 1999 & Gopherus agassizii & 41.7 & 2.8 \\
Geffen and Mendelssohn 1988 & Testudo kleinmanni & 26.0 & 0.4 \\
Guzmán and Stevenson 2008 & Chelonoidis denticulata & NA & 2.0 \\
Hailey 1989 & Testudo hermanni & 78.0 & 1.3 \\
Hailey and Coulson 1996 & Kinixys spekii & 172.0 & 0.6 \\
Hailey and Coulson 1996 & Stigmochelys pardalis & 435.0 & 20.0 \\
Innes et al. 2008 & Emydoidea blandingii & 30.9 & 1.2 \\
Kimmons \& Moll 2010 & Trachemys scripta & $N A$ & 1.9 \\
Kimmons \& Moll 2010 & Chelydra serpentina & $N A$ & 5.2 \\
Lambiris et al. 1989 & Kinixys spekii & $N A$ & 0.6 \\
Mazzotti et al. 2002 & Testudo hermanni & 55.9 & 1.3 \\
Millar and Blouin-Demers 2011 & Emydoidea blandingii & 214.8 & 1.2 \\
Moll \& Jansen 1995 & Rhinoclemmys funerea & NA & 0.9 \\
Moll \& Jansen 1995 & Rhinoclemmys annulata & $N A$ & 1.4 \\
Morrow et al. 2001 & Clemmys muhlenbergii & 3.3 & 0.2 \\
Moskovits and Kiester 1987 & Chelonoidis carbonaria & 0.4 & 2.0 \\
Moskovits and Kiester 1987 & Chelonoidis denticulata & 0.5 & 2.0 \\
Nieuwot 1996 & Terrapene ornata & 13.4 & 0.4 \\
Ross and Anderson 1990 & Emydoidea blandingii & 71.4 & 1.2 \\
Rowe 2003 & Chrysemys picta & 250.8 & 0.4 \\
Rowe and Moll 1991 & Emydoidea blandingii & 40.4 & 1.2 \\
Smith and Cherry 2016 & Glyptemys muhlenbergii & 14.1 & 0.1 \\
Strang 1983 & Clemmys insculpta & 108.0 & 0.2 \\
Strang 1983 & Terrapene carolina & 40.0 & 0.4 \\
Travis et al. 2014 & Chelydra serpentina & 147.5 & 5.2 \\
\hline \hline
\end{tabular}


S6: Studies from which data on the effect of chelonian gut passage on germination were extracted. References for Table 2 in the main text.

\begin{tabular}{|c|c|c|c|}
\hline Reference no. & Reference & Chelonian species & Plant species \\
\hline [1] & Waibel et. al. 2012 & Aldabrachelys gigantea & Adonidia merrillii \\
\hline [2] & Griffiths et. al. 2011 & Aldabrachelys gigantea & Diospyros egrettarum \\
\hline [3] & Moolna 2008 & Aldabrachelys gigantea & Diospyros egrettarum \\
\hline [4] & Andriantsaralaza et. al. 2013 & Aldabrachelys gigantea & Adansonia fony \\
\hline [5] & Hansen et. al. 2008 & Aldabrachelys gigantea & Syzygium mamillatum \\
\hline [1] & Waibel et. al. 2012 & Aldabrachelys gigantea & Mimusops coriacea \\
\hline [1] & Waibel et. al. 2012 & Aldabrachelys gigantea & Wikstroemia indica \\
\hline [1] & Waibel et. al. 2012 & Aldabrachelys gigantea & Lantana camara \\
\hline [6] & Varela and Bucher 2002 & Chelonoidis chilensis & Celtis pallida \\
\hline [6] & Varela and Bucher 2002 & Chelonoidis chilensis & Ziziphus mistol \\
\hline [7] & Guzmán and Stevenson 2008 & Chelonoidis denticulata & Rauvolfia micrantha \\
\hline [7] & Guzmán and Stevenson 2008 & Chelonoidis denticulata & Brosimum lactescens \\
\hline [7] & Guzmán and Stevenson 2008 & Chelonoidis denticulata & Ficus sp1. \\
\hline [7] & Guzmán and Stevenson 2008 & Chelonoidis denticulata & Ficus sp2. \\
\hline [8] & Jerozolimski et. al. 2009 & Chelonoidis denticulata & Genipa americana \\
\hline [7] & Guzmán and Stevenson 2008 & Chelonoidis denticulata & Cecropia sciadophylla \\
\hline [9] & Blake et. al. 2012 & Chelonoidis nigra & Opuntia echios \\
\hline [9] & Blake et. al. 2012 & Chelonoidis nigra & Hippomane mancinella \\
\hline [9] & Blake et. al. 2012 & Chelonoidis nigra & Psidium galapageium \\
\hline [9] & Blake et. al. 2012 & Chelonoidis nigra & Psidium guajava \\
\hline [9] & Blake et. al. 2012 & Chelonoidis nigra & Passiflora edulis \\
\hline [10] & Rick and Bowman 1961 & Chelonoidis porteri & Solanum siparunoides \\
\hline [11] & Kimmons and Moll 2010 & Chelydra serpentina & Morus sp. \\
\hline [11] & Kimmons and Moll 2010 & Chelydra serpentina & Echinochloa crus-galli \\
\hline [11] & Kimmons and Moll 2010 & Chelydra serpentina & Rumex crispus \\
\hline [12] & Calvino-Cancela et. al. 2007 & Emys orbicularis & Nymphaea alba \\
\hline [13] & Carlson et. al. 2003 & Gopherus polyphemus & Paspalum setaceum \\
\hline [14] & Elbers and Moll 2011 & Macrochelys temminckii & i Nyssa aquatica \\
\hline [14] & Elbers and Moll 2011 & Macrochelys temminckii & i Diospyros virginiana \\
\hline [14] & Elbers and Moll 2011 & Macrochelys temminckii & i Quercus phellos \\
\hline [15] & Sung et. al. 2016 & Platysternon megacepho & alunhachilus $s p$. \\
\hline [16] & Setlalekgomo and Sesinyi 2014 & Psammobates oculifer & Grewia flavescens \\
\hline [17] & Moll and Jansen 1995 & Rhinoclemmys annulata & Jacaratia dolichaula \\
\hline [17] & Moll and Jansen 1995 & Rhinoclemmys annulata & Faramea suerrensis \\
\hline [17] & Moll and Jansen 1995 & Rhinoclemmys funerea & Solanum pimpinellifoliur \\
\hline [18] & Braun and Brooks 1987 & Terrapene carolina & Arisaema triphyllum \\
\hline [19] & Liu et. al. 2004 & Terrapene carolina & Thrinax morrisii \\
\hline [18] & Braun and Brooks 1987 & Terrapene carolina & Podophyllum peltatum \\
\hline [20] & Rust and Roth 1981 & Terrapene carolina & Podophyllum peltatum \\
\hline [18] & Braun and Brooks 1987 & Terrapene carolina & Gaylussacia baccata \\
\hline [18] & Braun and Brooks 1987 & Terrapene carolina & Vaccinium vacillans \\
\hline [19] & Liu et. al. 2004 & Terrapene carolina & Byrsonima lucida \\
\hline [18] & Braun and Brooks 1987 & Terrapene carolina & Morus alba \\
\hline [18] & Braun and Brooks 1987 & Terrapene carolina & Phytolacca americana \\
\hline [19] & Liu et. al. 2004 & Terrapene carolina & Serenoa rapens \\
\hline [18] & Braun and Brooks 1987 & Terrapene carolina & Duchesnea indica \\
\hline [18] & Braun and Brooks 1987 & Terrapene carolina & Fragaria virginiana \\
\hline [18] & Braun and Brooks 1987 & Terrapene carolina & Prunus serofina \\
\hline [18] & Braun and Brooks 1987 & Terrapene carolina & Vitis aestivalis \\
\hline [18] & Braun and Brooks 1987 & Terrapene carolina & Vitis vulpina \\
\hline [18] & Braun and Brooks 1987 & Terrapene carolina & Sambucus canadensis \\
\hline
\end{tabular}


bioRxiv preprint doi: https://doi.org/10.1101/379933; this version posted July 30,2018. The copyright holder for this preprint (which was not certified by peer review) is the author/funder, who has granted bioRxiv a license to display the preprint in perpetuity. It is made available under aCC-BY-NC-ND 4.0 International license.

Falcón et al. Seed dispersal by chelonians

\begin{tabular}{llll}
\hline$[21]$ & Cobo and Andandreu 1988 & testudo graeca & Hypochaeris glabra \\
{$[21]$} & Cobo and Andandreu 1988 & Testudo graeca & Spergula arvensis \\
{$[21]$} & Cobo and Andandreu 1988 & Testudo graeca & Ornithophus sativus \\
{$[21]$} & Cobo and Andandreu 1988 & Testudo graeca & Briza maxima \\
{$[21]$} & Cobo and Andandreu 1988 & Testudo graeca & Rumex bucephalophorus \\
{$[22]$} & Kimmons and Moll 2010 & Trachemys scripta & Morus sp. \\
{$[22]$} & Kimmons and Moll 2010 & Trachemys scripta & Echinochloa crus-galli \\
{$[22]$} & Kimmons and Moll 2010 & Trachemys scripta & Rumex crispus \\
{$[23]$} & Kennet and Russel-Smith 1993 & Elseya dentata & Terminalia erythrocarpa \\
{$[23]$} & Kennet and Russel-Smith 1993 & Elseya dentata & Terminalia microcarpa \\
{$[23]$} & Kennet and Russel-Smith 1993 & Elseya dentata & Ficus racemosa \\
{$[23]$} & Kennet and Russel-Smith 1993 & Elseya dentata & Syzygium forte \\
{$[23]$} & Kennet and Russel-Smith 1993 & Elseya dentata & Pandanus aquaticus \\
{$[23]$} & Kennet and Russel-Smith 1993 & Elseya dentata & Cyclophyllum schultzii \\
{$[23]$} & Kennet and Russel-Smith 1993 & Elseya dentata & Nauclea orientalis \\
\hline \hline
\end{tabular}

